) 

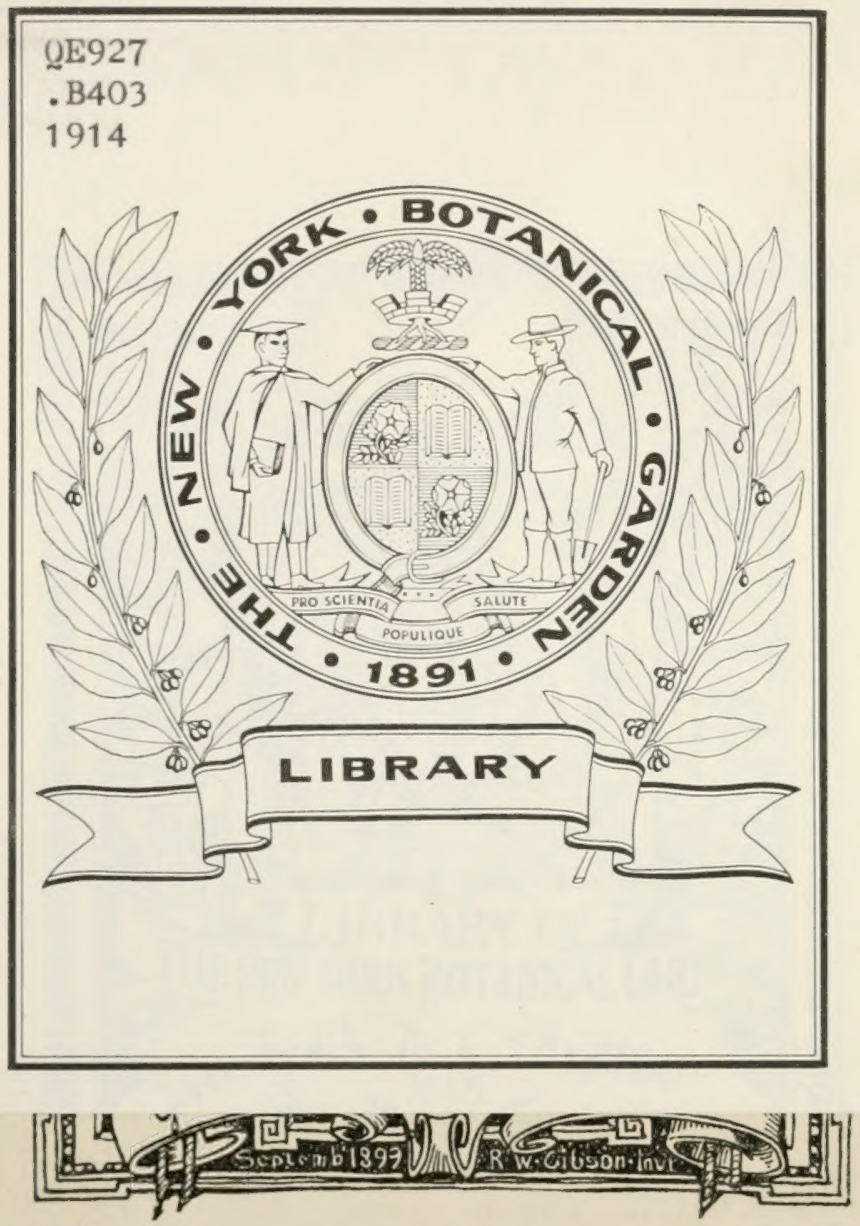






\section{THE AFFINITIES AND DISTRIBUTION OF THE LOWER EOCENE FLORA OF SOUTHEASTERN NORTH AMERICA}

BY EDWARD WILBER BERRY

Reprinted from

Proceedings of the American Philosophical Society Vol. LIII, No. 214, June-July, 1914 . 


$$
\begin{aligned}
& \text { QE927 } \\
& .3403 \\
& 1914
\end{aligned}
$$




\section{THE AFFINITIES AND DISTRIBUTION OF THE LOWER EOCENE FLORA OF SOUTHEASTERN NORTH AMERICA.}

By EDWARD WILBER BERRY.

(Read April 25, 19I4.)

INTRODUCTION.

Three years ago I made a preliminary announcement before this Society ${ }^{1}$ concerning the fossil floras of southeastern North America. I have, in the interim, completed a monograph of the extensive and especially well preserved plants of the Lower Eocene, and it is some of the results of this detailed study that are given in the present communication. This work has been done under the auspices of the United States Geological Survey, to the director of which organization I am indebted for permission to publish the following preliminary abstract. I also wish to express my great indebtedness to Dr. T. Wayland Vaughan, who has had general charge of the Coastal Plain investigations and to whom great credit is due for their comprehensive character.

Physical Conditions Indicated by the Flora.

There is no part of North America so favorably situated for the study of the floras which preceded the present, extending backward

${ }_{1}^{1}$ Proc. Amer. Philos. Soc., Vol. 50, No. 199, I9II.

Reprinted from Proceedings American Philosophical Society, Vol. liii., rgit 
to a time which marks the first recorded appearance of angiosperms, as that of the South Atlantic and Gulf states. No single part of North America contains so continuous a series of Tertiary deposits carrying fossil plants. In this area are found abundant floras in the lower and middle stages of the Eocene, a small flora in the Upper Eocene, considerable floras in the Oligocene, some in the later Miocene, and rather abundant fossil plants in the Pliocene, as well as numerous Pleistocene deposits carrying fossil plants. The Rocky Mountain region is rich in Eocene fossil plants and there are some Miocene floras, but practically no Oligocene or Pliocene floras are known. The Pacific coast region likewise furnishes Eocene and Miocene fossil plants but none of Oligocene age.

The fossil floras of the Coastal Plain are found in an area where it is possible to attain to some measure of accuracy in predicating the general character and course of ocean currents and winds and other physical features of the environment. On the other hand the western floras just mentioned grew in areas where vulcanism was great at times; in areas of great orogenic activity, where changes in topography were numerous and elevations of several thousands of feet are recorded; areas in which climatic conditions not only varied from place to place, but passed through a large cycle of secular changes. All these factors greatly complicate the floral history.

The floras of the southern Coastal Plain are moreover checked for the most part by very abundant marine fauna in intercalated beds, or the plant-bearing beds which represent the coastal swamps and the shallow water deposition of the old embayment merge laterally with the contemporaneous limestones or marls which were forming in more open waters along the coasts to the southward, so that there is a considerable body of facts bearing on depth, character of the bottom, and marine temperatures, with which to compare land temperatures. These criteria have been admirably worked out for the Florida area by Doctors Dall and Vaughan for the post-Eocene and their results furnished a reliable datum plan for the deductions to be derived from the study of the fossil floras of those times.

With the exception of fragments of the petrified stems of conifers, palms and dicotyledons the plant-remains are in the form of impressions, mostly of foliage, but with a goodly representation 
of fruits and seeds, and in some few cases even flowers are preserved.

While the oscillations of the embayment area have been numerous they have been, as I have just mentioned, inconsiderable in amount, only a few hundred feet at most, and the coastal region has uniformly been one of slight relief. The various floras show an almost complete absence of upland types. This is in striking contrast to the European older Tertiary floras. The only large area of the globe which has been thoroughly studied-Europe-was far less stable than this region in Tertiary times and lying much farther toward the pole was subsequently subjected to the rigors of Pleistocene conditions whose influence never reached our southern states.

The paleobotanical record of the Atlantic and Gulf Coastal Plain furnishes a history which extends back as I have just mentioned beyond the oldest known angiosperms to a time (Lower Cretaceous) when the flora was made up almost entirely of tree-ferns, conifers and those interesting cycadophytes (Cycadeoidea) whose trunks are sometimes preserved with such marvelous perfection that the outlines of the embryos in the ovules can often be made out in detail. Coming a step nearer my present theme, a step of some millions of years from the Lower into the Upper Cretaceous, we find the first great modernization of the floras of the world due to the seemingly sudden evolution of the main types of angiosperms. These Upper Cretaceous floras are well represented in the Coastal Plain from Marthas Vineyard to Texas. They extend northward to Greenland and southward to Argentina in South America, and are found to indicate very different physical conditions from those which prevail at the present time. I do not intend, however, to dwell upon the Upper Cretaceous floras in this connection but pass to a consideration of the succeeding Eocene epoch of plant evolution.

The Eocene as defined by Lyell was marked by the dawn of the recent species of marine mollusca. It is equally well marked by the sudden expansion and evolution of modern types of plants after a long antecedent Cretaceous development. The floras become thoroughly modernized as compared with those which preceded them, although they are still very different in their general facies and distribution from those of the present. 
In the earliest epoch of the Eocene known as the Midway, the relations of sea and land in the Gulf area differed in only minor particulars from that of the late Cretaceous. The waters of the Mississippi Gulf were, however, deeper. This factor combined with a much less influx of fresh water from the tributary streams, due in some measure to the low relief of the land, enabled marine faunas to reach well toward the head of the gulf. These faunas indicate subtropical buttom temperatures northward as far as Paducah, Ky. The

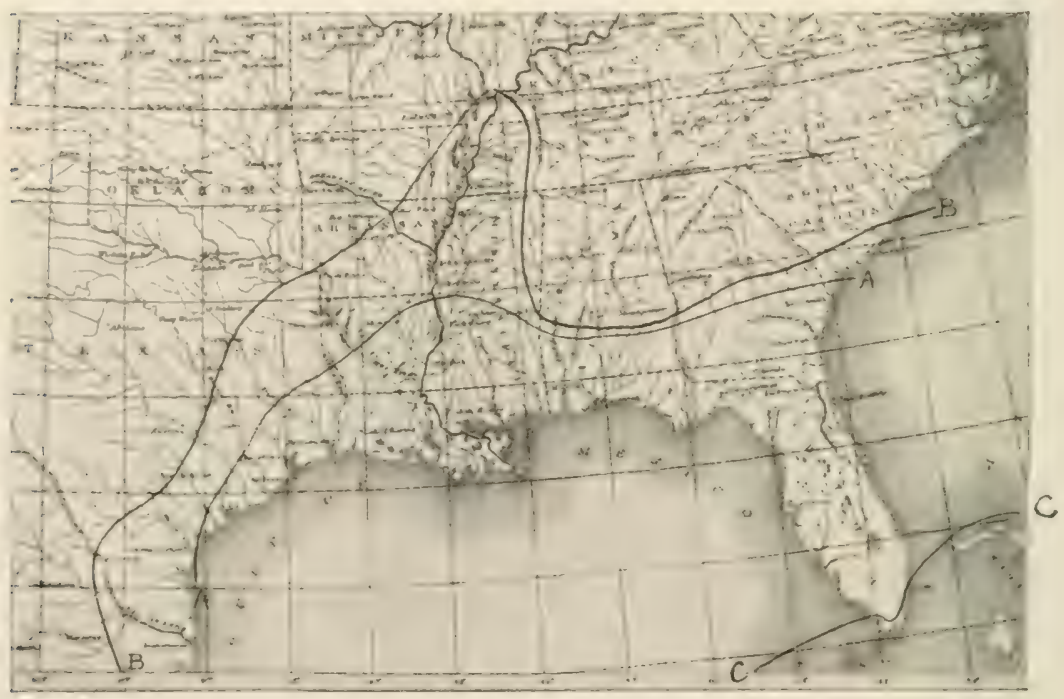

Fig. I. Sketch map showing the approximate position of the shore line, $A-A$, at the beginning of the Wilcox transgression and $B-B$ the area covered by the Wilcox sea during its maximum transgression. C-C, the extreme northern limit of the Willcox flora under existing climatic conditions.

knwn floras are very santy and minsatisfactory and in the present state of our knowledge do not merit an extended discussion. 'The maximum transgression of the sea during the Midway epoch is shown on the accompanying sketch map (Fig. I).

The Midway Eocene was succeeded by a long interval during which the sea is believed to have withdrawn southward at least as far as the postion inlicated on the accompanying sketch map) (Fig. $I, A-A)$, since terrestrial conditions are known at the extreme base 
of the Wilcox in the most southerly areas of their outcrop. This interval of emergence of the embayment area was followed by an equally long interval during which a great thickness of deposits was laid down that are collectively known as the Wilcox group. The character of these sediments and their faunas show that the Mississippi gulf was somewhat restricted and much shallower than in the preceding epoch, with true marine conditions prevalent only in its lower portion. The shores were low and relatively flat. They were flanked by current- or ware-built bars and separated from the mainland by shallow inlets or lagoons. The lower courses of the streams were transformed into shallow estuaries or broad swamps through which the smaller streams meandered.

The maximum area covered or underlain by. Wilcox deposits is also indicated on the accompanying sketch map (Fig. I, $B-B$ ) which shows approximately the shore line along which the vegetation migrated. As has been already remarked the IVilcox deposits have yielded one of the most extensive of known fossil floras, an assemblage of extinct species which sheds considerable light on the physical conditions of the marginal lands of Wilcox time.

Before taking up in detail the evidence of the flora I wish to point out certain general climatic conditions based on cosmic causes and deduced for the Wilcox from studies of recent climates.

It is to be noted that the factors governing atmospheric circulation are general and not local and the relatively slight changes in the relation of land to sea in Wilcox time as compared with the present are entirely too small to have caused much modification of existing conditions. Then as now there was a persistent area of high pressure over the Jorth Atlantic and a low over the continent. Consequently the winds were prevailingly from the east. Cyclonic disturbances like those that originate today in the Gulf of Mexico or those more violent and widespread storms of the West Indian hurricane type which today originate in the Caribbean Sea would traverse at least a part of the Mississippi embayment. So large an area of shallow more or less landlocked water would have a very appreciable effect in raising total temperatures and in the prevention of widely separated extremes. At the same time it would increase the rainfall and increase the width of the marginal lands over which this angmented 
rainfall would he effective. Whether or not this would be sufficient to furnish the subtrupical conclitions that the flora seems to indicate is doulut ful. Speculation regarding the Eocene climate of the world as a whole is perhaps ont of place, nevertheless it remains true that the sum total of paleontologic evidence indicates that the familiar succession of scasons or of types of regetation in passing from the luxuriant tropics to the ice-capped poles did not hold good for the Eocenc. I'aleobotanists have long maintained that the existing climate is essentially a Pleistocene climate of an interglacial character and that for the great bulk of geologic time uniformity and not differentiation has been the rule rather than the exception. While the older paleobotanists were inclined to overestimate the conditions of torridity, it remains true that from the Lower Cretaceous until toward the close of the ()ligocene, not to mention still older floras of more remote botanical affinities, whenever fossil floras are found, from beneath the Equator to within the Arctic circle, they show a degree of uniformity that proves that former climates were secularly unlike these of today and as is obvions this floral evidence would be erually convincing if all the vast number of fossil plants were simply called Phyllites as in Schlotheim's day and no attempt were made to determine their botanical affinity.

The student of fossil floras is naturally more sanguine and enthusiastic in preflicting former physical conditions than perhaps is warranted by his facts. When however a common Upper Cretaceous flora can be traced from Texas to Greenland or when we find in the Eocene such unmistakable forms as Artocarpus leares, Engelhardtiu fruits, and nuts of the Nipa palm associated with forms as characteristic as ferns of the genus. tcrostichum all extending almost across the temperate zone in both the eastern and western hemispheres it would seem that the burden of proof that climates were not very different from those of today rests with the plysicist and not with the paleobotanist.

It may be noted that all of the IVilcox plants, almost without exception, are plants whose modern representatives inhabit the warmer farts of the carth. There is not a single strictly temperate type in the while assemblage, the nearest approach to such types being in the genera Juglems, Myrica, Magnolia, Cercis, Mlex, Nyssa, and Frar- 
inus, and in all of these genera or closely related ones there are existing tropical forms. None extend beyond the warmer parts of the temperate zone and some of these as in the case of Juglans and Frarinus indicate in their compound leaves their tropical ancestry, as was first pointed out by Grisebach. The ferns are all tropical types and their relative unimportance in the Wilcox flora furthermore indicates that the major part of this flora is a strand flora. This is shown more especially by forms like the Nipa palm which never grows outside of tidal marshes, by Conocarpus, Laguncularia and Aricennia which inhabit like situations; by coastal marsh or lagoon plants like Cama, Trapa and Sabalites; and by the large number of strand types that inhabit beaches or the jungle behind the beach ridges or dunes. The more striking of these genera are Myrica, Artocarpus, Ficus, Coccolobis, Pisonia, Anona, Capparis, Chrysobalanus, various Lauraceæ, Apocynaceæ, Sapotaceæ and Leguminosæ, Fagara, Drypetes, Mctopium, Ilerr, Celastrus, Sapindus, Dodonaa, Reynosia, Rhammus, Myrcia, Eugenia, Laguncularia, Combretum, Terminalia, Cordia, Citharexylon, Exostema and Guettarda.

It needs but a slight acquaintance with the existing Antillean flora or that of the Florida keys, or in lieu of actual acquaintance a perusal of the as yet too few ecological discussions of the flora of the American tropics or even of Schimper's classic Indo- Malayan strand flora to see at once that the general facies of the Wilcox flora is overwhelmingly that of a strand flora of which some of the elements indicate that they grew on the sandy beaches, others in muddy tidal flats, others between or behind dunes or beach ridges, and others in estuary bayous or marshes. None of the forms can certainly be considered as inland or upland types. Even genera like Banksia which is not usually considered a coastal type in the existing flora furnishes Banksia marginata Cav. to the coastal sand dunes of South Australia (Tepper) and several others species of the genus occur on the dunes of Queensland, Victoria and western Australia.

Little has been written of the plant associations of the American tropics and collectors notes almost always fail to adequately describe habitats. While the marginal Wilcox lands were low there was such a large area of continent to the northward to draw from, and the long coast furnishes such varied edaphic conditions, that the flora 
was far richer than floras of small insular areas of the American tropics of the present, as for example, that of the Bahamas which are relatively close to mainland, where in addition to difficulties of introduction there is relatively great uniformity of eclaphic factors and directly adverse factors such as winds, which limit the floral display.

Without pursuing the subject in greater letail it may be assumed to be proven that the Wilcox flora is a typical coastal flora. Compares with recent coastal floras it is at once apparent that its affinities are entirely with those of tropical and subtropical America. It has much in common with the Bahaman flora and that of the Florida keys, but is far richer in arborescent forms. Comparisons with the larger islands of the West Indies show more elements in common, such differences as are apparent being due to the prevalence of porous coral rock along these recent shores while the Wilcox shores were not of this character. The most complete agreement is furnished by the floras along the Caribbean coast from Central America to northern lirazil. A considerable number of genera found in the IVilcox flora do not range through the $\mathrm{West}$ Indies at the present time and the explanation seems to be that the Wilcox flora more closely resembles the original flora of the whole American equatorial region which became restricted during the epeirogenetic and climatic changes of the Miocene or Pleistocene and the elements now lacking in the Viest Indies never regained all of the area of distribution lost at that time.

It may seem improper to say that a flora with abundant forms of Artocarpus, Nipa, Cimnamomum, Banksia, etc., is entirely American in character but if the brief sketches in the botanical discussion which follows are read it will be obvious that these genera, oriental in the existing flora, were cosmopolitan in the early Tertiary, so that it would he entirely misleading to draw conclusions from existing distribution alone.

The Wilcox waters of the upper embayment were always shalluw; there were fringing bars and lagoons as well as deltas, estuaries and swampy hayous. The deposits in places show river action and streams shifting ahout over sand flats. Regarding actual temperatures so little is known after all of the relations of modern plants to their climatic environment that results can only be qualitative and not quantitative. 
It is obvious that the flora could not have existed if the region was ever visited by frost, and temperatures appear to have been like those found today on the Florida keys. Aside from the meteorological certainty that there was a wide coastal belt of abundant precipitation, there is the confirmation furnished by the flora itself. It would seem to me proper to compare the Wilcox flora with those of the regions to which the somewhat loosely used term subtropical rain forest is applied by plant geographers. Too little is known of the Midway flora for accurate comparisons. Compared with the Upper Cretaceous flora of the embayment area, in which however 40 percent of the genera are extinct, the Wilcox would seem to have become more tropical, a progression from what might be termed a warm temperate to a subtropical rain forest. On the other hand the floras as well as the faunas show a gradual increase of tropical conditions in the later Eocene which culminate in the Oligocene, the flora of which in southeastern North America is strictly tropical.

Lianas were apparently not as common in the Wilcox as they are in the existing floras with which it has been compared. No traces of the Bignoniacer, so common in the American tropics, have been detected, the scandent types being represented by Lygodium, Aristolochia, Malpighiacere, Canazalia, Pisonia (?), and Zizyphus, I am inclined to think that the great uniformity of climatic conditions together with the abundant rainfall have combined to make the II ilcox flora seem more tropical in character than was actually the case. That reef corals are not found in the Wilcox is, I believe, entirely due to physical conditions other than those of temperature as Vaughan ${ }^{2}$ has shown to be the case so often in such a striking manner in recent seas.

I have indicated upon the sketch map (Fig. I $C-C$ ) what I conceive would be the northern linit of range of the IVilcox flora under existing climatic conditions in southeastern North America.

It would seem to be probable that most of the generic types of the Wilcox were differentiated by the close of the Cretaceous. If the equatorial region of America was the place of origin of a majority of those types which have not as yet been recorded from the Cretaceous as I believe to be the case, they must have spread northward along 2 Vaughan, T. W., Journ. Wash. Acad. Sci., Vol. 4, pp. 26-34, I914. 
the Mississippi Gulf either during the Cretaceous-Eocene interval, during the Milway or during the Midway-Jlilex interval. While the time available for this northward dispersal was thus sufficiently long to acconnt for the migration of eren the most slowly spreading forms a short statement on the adaptations and agencies of this dispersal is not without interest. The IIilcox genera with winged fruits or seeds are Engelhardtia, Paracngchardtia, Dodonca, Palinmus, Frarinus and the Proteacex and Malpighiacex. None of these are capalble of long flights except those of the last two families and these during high winds might readily be carried for miles along coasts, although it is doubtful if they could have crossed great stretches of open water, even through the agency of a West Indian hurricane. The heavier winged fruits such as those of Engelhardtia, I'aracngelhardtia, Paliurus, Dodonca and Frarinus float readily, although as far as I know there is no experimental data to show how long they float in oceanic waters without losing their vitality. Certainly Dodonca has reached the Bermudas in recent times through the agency of the Gulf Stream. Among the Wilcox forms more or less adapted for floating the following genera may be enumerated: Nipadites, Canna, Taxodium, Pisonia, Sapindus, Stcruliocarpus, Trapa, Ariccmia, Solanites, Exostema and the Combretacer. Among the foregoing Canna, Tarodium, Trapa and Exostcma are scarcely arlapted for sea voyages while on the other hand, Nipadites, Sapindus, Sterculiocarpus, Aricennia and the Combretacex are singularly adapted for dispersal by ocean currents and would be in the van of forms colonizing the shores of the transgressing Wilcox sea.

A large number of the Wilcox genera had fleshy or drupacenus fruits and formed the dietary of both mammals and birds. Imong these the following may be mentioned: Myrica, Ficus, Coccolobis, Magmolia. Anona, Isimina, Chrysobalanus, Simaruba, all the Lauracere, Ilicacea, Cehastracea, Myrtacex, Ebenacex, Sapotacex, Meliacea, Euphorbiaceat, Anacarliacer, Zizyphus, Guettarda, Citharerylon, Cordia, Osmanthus, Icacorea, Rhamnus and Reynosia. Many of these have crustaceous stones that pass minjured through birds or are voided with their vitality unimpaired and these could undoultsedly be carried long distances over seas. Even in the case of soft seerls like those of a large number of the Leguminosie it has been 
found that birds that have eaten greedily often void them uninjured and others meet with fatalities before the seeds are digested and these constitute by no means unimportant factors in distribution. Clement Reid in his discussion of the origin of the British flora gives an instance of a dead wood-pigeon with beans sprouting from its crop, and when it is remembered what a great percentage of birds meet an untimely end it is conceivable that a single hurricane might readily be the means of introducing new forms from the Antilles upon the Wilcox coast. Other Leguminosæ, although more rarely, are dispersed by ocean currents, as is the case in an eminent degree with the modern Entada or snuffbox seabean.

All of the storms moved from the equator northward, the main ocean currents had the same general direction, while the prevailing winds were easterly so that all of these important factors combined in causing a relatively rapid introduction and spreading of forms along the IVilcox coasts, so that given favorable climatic conditions and many of the forms need not have taken the time to spread from Central or South America along continuous coasts.

\section{Botanical Character of the Flora.}

That the method by which the bulk of the determinations in the present study are made rests upon real and not fanciful affinities is of vital importance, since the resulting climatic and other physical data are largely controlled by these facts. The case is not as intricate or as hopeless as it might seem to the student who remembers the thousand of living and extinct genera. De Candolle estimated the total number of flowering plants to be about 250,000 species. This figure is swollen by the great multiplication of herbaceous species in recent geologic times. The ratio of arborescent to herbaceous types was much greater in the Tertiary than it is at the present time and it seems probable that trees were actually more abundant and varied than in the existing flora. This was certainly true for all Tertiary floras outside the torrid zone and may be readily proved by a consideration of the Eocene floras of North America, the Miocene floras of Europe or to cite an extreme case the Tertiary floras of the Arctic and Antarctic regions.

While the arborescent flora of the temperate zone is relatively 
meacer, trees increase in prasing toward the equator. For cxample the state of Maryland which is in latitude $38^{\circ}$ to $39^{\circ} 30^{\prime}$ is in effect a cruss section of the Coastal I'lain, I'iedmont I'latean and the . Neeghany. Wountains with great differences of climate, topregraghy and soils. It is moreover the meeting ground for plants of northern and southern range. In spite of these facts there are only about $\mathrm{I}_{50}$ arhorecent forms in its flora. (On the other hand in Small's recently published Trees of Florida (1913) there are 366 native and naturalized arborescent forms, and if Fiorida furnished much altitudinal variation the number would be much larger. For example the arborescent flora of the Philippine Islands includes $66_{5}$ native species and many adelitional introduced forms. Even remote oceanic islands if of sufficient size and topographic variety to overcome the adverse action of winds have a large arborescent flora. Thus the Sandwich Islands have 225 mative species of trees distributed annong +5 fanlilic: the larger heing the Rutacese (32 species), Rubiacee (3I species), Campantlacer ( I 5 species), Araliacex (It species), l'ittosporace (I2 species), Palmacer (I species), Myrsinacer (I I species), and Malvacex (Io species). ${ }^{3}$

The general physical conditions of a remote geological epoch may he more or less completely deduced in advance from the character $(. \bar{f}$ the sediments: the run-off from the land can be approximaterl and conseguently the altitule of the land and the probable rainfall as we!l as any periodicity in these factors. These are all reflected in the sediments. Work like that of Vaughan ${ }^{4}$ on the deposits of the IF Inricla keys or that of Drew on the part played by lenitrifying bacteria in the formation of limestones, enables a careful palerbotanist to in a measure predict the character of the flora that clothed the marginal lands. In deposits that teem with the remains of marine life as do many of the Tertiary formations of southeastern North America it is possible to arrive at very close approximations of the actual temperatures of the coastal waters. It may be safely assumerl that boreal or temperate foras did not flourish in proximity to trop-

${ }^{3}$ Rock, J. F., "The Indigenous Trees of the Hawaiian Islands," Honolulu, 1913.

1 Vaughan, T. W., Carnegic Institution, Publication I33, I9I0.

5 Drew, G. H., Yearbook, Carnegic Institution, No. 10, I911. 
ical marine faunas: that plants reflected their environment in the past as in the present.

A considerable number of botanists love to dwell upon the temerity of their paleobotanical friends in venturing to determine leaf impressions. I admit at the outset that some determinations are much too sanguine, especially when based upon fragmentary materials. There is more or less convergence in foliar characters in unrelated or remotely related families and there is also considerable variation in the leaves of a single species, but the fact remains that foliar characters in general are more conservative than those derived from almost any other organs of plants. They are subjected to less complex environmental factors and always have been. It should be remembered that characters less essential in the vital activities of plant, such as leaf form, when once acquired, may continue practically unclianged for thousands of years and afford a surer clue to relationship than characters more immediately within the field of action of natural selection. This is shown by the persistence of fern fronds on the Paleozoic Pteridosperms; by the uniformity of Cycad-like fronds from the Permian to the Cretaceous; and by the striking persistence of dicotyledonous foliar types from the Mid-Cretaceous to the present. It is paralleled by Dall's observations on the persistence of superficial and ornamental shell characters in the Mollusca from the Cretaceous to the Recent.

The opinion I mention in a preceding paragraph is mainly the result of ignorance both of foliar characteristics and paleobotanical literature, and an unwillingness to spend the time necessary for a mastery of the subject. I have tested systematic botanists time and again with recent leaves and the results are not especially creditable. They generally know that leaves are green in color and that some are simple and others compound: they may even know whether the margins are entire or toothed, but the venation is usually a closed book. I know of but one manual that pretends to pay careful attention to foliar characters and that is Sargent's "Tree Book" and even here the figures pay no attention to venation. ${ }^{\circ}$ In the tropics where flowers and fruits are often unobtainable or beyond reach it is easy to

"Sudworth's "Trees of the Pacific Slope" is the most admirable work in this respect that has ever been published. 
learn to recognize most arborescent forms by their habit and foliage but to most botanists, systematic or otherwise, anything beyond the floral structure receives but scant attention.

It is reasonable to conclude that palms and tree-ferns were never bureal plants that have in the course of ages become restricted to the tropics as Cammayr once suggested in an effort to explain their presence within the Arctic circle on other than climatic grounds. Uniformity of conditions is the founlation upon which the whole fabric of our knowledge of past events rests and it is just as unscientific to assume that the carrying power of water was not conclitioned by its velocity luring the Tertiary as it is to assume that insolation, humiclity, rainfall, winds and all the other factors that constituted the environment of the vegetation, had effects different in kind from their effects on the living flora.

In a study of this sort the chief emphasis should be based upon comparisons with the existing relatives of the fossil forms and not upon a search among the illustrations of works devoted to the stucly of previously described forms, often from remote regions, for what appears similar. The latter should not be neglected however and no descriptions are complete unless they include a discussion of the resemblances and differences of previously described forms that show similarities to the form in hand with their geologic and geographic destribution. Even the most trivial characters of the fossil shotild be carefully noterl since all are or will become valuable in future stuclies. The living representatives, their habitat, range and variation are of the greatest importance in determining paleoecology.

[nless there is clear evidence of transportation it may he assumed that strand plants and upland plants will not be found in association and if such seems to be the case, additional study may reveal the errors of determination.

That all forras are dynamic and not static: that all their elements are more or less plastic in their reactions to the infinite complexity of their enviromment raises a certain amount of secpticism regarding the methods and results of what may be called paleocology. This is especially true since so little is known regarding the precise relations between existing plants and their environment. At the same time there is mo wher method available and it must be consilered to be a 
legitimate method until negatived in human experience. If it be assumed untrue there is no limit to idle speculations as futile as those of medieval times.

The Wilcox flora as described in the present study comprises considerably more than 300 species - the exact number is without significance since it is so largely dependant on accidents of preservation and discovery, and since it is also considerably influenced by the evaluation of specific characters. The number might readily be increased to 400 if fragments of new forms were considered the basis for the description of species.

This flora is therefore one of the largest floras as yet known from a single geologic horizon in a single area, although it is considerably overshadowed numerically by the so-called Fort Union flora of the Rocky Mountain Province, which however covers a greater geographic area and a longer interval of time.

Compared with foreign Eocene floras of similar age it may be noted that Ettingshausen enumerated 72 genera and 200 species from the London Clay of the Island of Sheppey ${ }^{7}$ and II6 genera and 274 species from Alum Bay on the Isle of Wight. ${ }^{8}$ I mention these two English floras specifically since while never adequately described they are at least partly contemporaneous with that of the Wilcox, as I hope to show in the chapter on correlation, and they therefore offer various interesting details for comparison as will appear on subsequent pages.

The Wilcox flora comprises 128 genera in 59 families and 33 orders. The Thallophyta are represented by a few species of leafspot fungi, and if the student were to follow the fashion set by the older continental paleobotanists the so-called species of spot-fungi could be increased many fold, as I have only picked out for enumeration certain conspicuous or characteristic types. The Bryophyta, as is usually the case in fossil floras, are entirely unrepresented, although the sediments are often of a character to have preserved them in perfection if they had been present, and the assumption is logical that they were either confined to more northern latitudes at this time or were an exceedingly minor element in the flora. The Pterido-

7 Ettingshausen, Proc. Roy. Soc. Lond., Vol. 29, I879, pp. 388-396.

8 Ettingshausen, Ibidem, Vol. 30, I880, pp. 228-236. 
f) hytal which are such a preponderating element in all fossil floras up to the Iidkle Cretacents are represented by a doubtfully determined Lycopod and six species of ferns.

Ferns are anong the most abunlant (in specific differentiation) rascular plants in the flora of tropical America, the island of Jamaica being especially celebrated for its fern flora. Grisebach enmmerated 340 species of ferns in his "Flora of the British West Indies" published in I864. In Urban's more recent work I82 species of the Inolypodiacere alone are recorded from Porto Rico. The following five genera have been recognized in the II ilcox: Ineimia, Lygodium, Asplenium, I'teris and Meniphlyloides-each represented by a single species except the genus Asplenium which has two species. While six species seems a small number of ferns in a sulbtropical flora like that of the WiIcox it is just twice as many as have been found in the contemporaneous deposits of Alum Bay on the Isle of Wight where the remains of an extensive flora is preserved in the pipe-clays. The explanation of this seeming disparity hetween the fern representation in the Lower Eucene and in molern floras is readily formulated and it will also indicate the reasons for thinking that the real IVilcox fern flora if it were available for study would be a rich and varied one, comparable at least with the existing fern flora of the lowlands of subtropical America.

The known Wilcox flora is almost entirely a coastal flora made up very largely of strand types. Very few elements in it can be legitimately considered as derived from inland areas by stream transportation, in fact their condition of preservation alone proves that they grew in the immediate vicinity of where they are now found as fossils. With a few striking exceptions the existing tropical and subtropical fern floras are floras of humid inland or upland habitats. for example the majorty of the Jamaican ferns are found on the Jlue Mountains. The most striking exception to this statement is the genus firostichum which strangely enough has not yet been positively recognizer in the Wiloox flora although it was widespread along the shores of the Mississippi Gulf in the succeeding Middle Eocene (Claiborne) and Lower Oligocene (Vickshurg) floras, as alumclant apparcutly as it is in the existing flora of tropical tidal marhes in both the Eastern and the Western Ifemispheres. Inother 
fern type liable to be present in coastal thickets is the genus Ly'godium with its scandent habit, and this genus is represented in the Wilcox flora by both sterile and fertile fronds. It is likewise common in the Claiborne and Vicksburg floras and in Tertiary floras generally. Besides Ly'godium, the family Schizaeacex is represented by a species of Ancimia which must also be considered to have been a coastal type in the early Eocene as are some of its species at the present time, since very similar species of Aneimia are found at a very large number of Eocene coastal deposits both in this country and abroad.

The remaining four species of Wilcox ferns are all referable to the fanily Polypodiacex which is the dominant existing family of the fern phylum. The two species of Asplenimm are types readily matched by existing Central American species. The Pteris, not certainly identified as a true species of this common cosmopolitan type, had stout coriaceous fronds and may have been transported since it occurs at only two localities in the Wilcox and at one of them it is in a fragmentary condition. This supposition receives some support from its presence in the basal Eocene of the Rocky Mountain province after the sea had withdrawn from that area and after there had been a large amount of volcanic activity and more or less uplift. The genus I/eniphylloides is a unique type as yet peculiar to the IVilcox flora although it is closely related to the similarly unique genus Meniphyllum Ettingshausen and Gardner from the Middle Eocene (Lutetian) of England and both are closely related to and possibly the progenitors of the existing genus Meniscium which has at least one species that is close to the Wilcox form. Meniphylloides is only found at two localities near the top of the IVilcox and its probable habitat is not known. The remains are broken but are associated with a typical strand flora.

It will be seen that of the Wilcox ferns whose habitats can be surmised all are coastal types and when we recall that the mainland was relatively low throughout Wilcox time it is not surprising that the ferns are not more strongly represented. By a specialization of habitat in modern equatorial regions a considerable proportion of the flora becomes epiphytic, the smaller ferns being commonly so. None of the members of the extensive Wilcox flora can be regarded PROC. AMER. PHIL. SOC., LIII, 214 J, P'RINTED JULY IO, 1914. 
as epiphytes with the possible exception of I-ycopodites? colignitica which is such a rare and poorly represented form that it is without significance. Apparently epiphytes were not conspicuous in the IVilcox coastal floras so that this pussille source of supply for adlitional fern species is also eliminated.

The Gymnospermæ so conspicuous in Mesozoic floras are relatively unimportant in the Wilcox flora, a feature due to their general unimportance in Cenozoic floras and to their intolerance of the habitats and climatic conditions indicated by the tout ensemble of the IVilcox thra. All of the five IIilcox gymnosperms are referrecl to the relatively modern family. P'inacere and none of the genera are especially close to Mesozoic types. The Cycadacere which might he expected to be represented by Zamia-like forms have not been fumnl although the presence of typical If illiamsonia fructifications in the Upper Cretaceous of the coastal plain inclicates that the Cycarl phylum had not been long extinct in this area.

The Angiospermae, beyond all odds the dominant type in existing floras, was as clearly dominant in Wilcox time since to it belong over 94 per cent. of the known Wilcox flora. Of these numerous angiosperms only seven are referable to the Monocotyledonx. It is true the number of monocotyledons might have been increased by describing the varions sedge or grass-like fragments that are not uncommon at certain localities. None of these have, however, been dignified by names except a single form each of Poacites and Cyporites which were only retained since they were already in the literature. That only three species of palms have been recognized is remarkable since palms were well differentiated at this time and varions genera such as Phanicites, Thrinat, Geonoma, Bactrites, Manicaria, etc., are recognizer in our later Tertiaries. In the contemporaneous deposits of Sheppey of the 30 monocotyledons enumerated by Ettingshausen (op). (it., p. 34.3122 species are palms. On the other hand the Alum lay flora contemporaneous and not far distant from the Slieppey ileposits furmisher mly fo monocotyledons. This contrast inclicates that the fruits accumulaterl at Sheppey in the delta of an Eocene river system contain interior forms not present in the coastal region represented by the . llum liay clays and that inland from the Wilcox coast the display of monocotyledons suitable to the IVileox envirommental conclitions fourished but failed of preservation. 
Since the early Eocene floras of Europe are so much like those of southeastern North America an enumeration of the Sheppey palms is of considerable interest. They include the genera Nipa, Enocarpus, Areca, Iriartca, Licistonia, Sabal, Chamarops, Thrinar, Bactris, Astcrocaryum, and Elais. Of these Nipa and Sabal are represented in the ITilcox flora while Thrinar and Bactrites are present in the embayment area in the Middle Eocene (Claiborne). The Order Palmales, or more properly Arecales, has a single existing family the Arecarex (Palmæ) with about I50 genera and considerably orer a thonsand existing species about equally divided between the oriental and occidental tropics. There are no temperate outliers, although some species extend for considerable distances into the temperate zone as for example Sabal adansonii which ranges northward along the Atlantic Coast as far as North Carolina. The present distribution of the palms is a good illustration of modern continental floral diversities succeeding a Tertiary cosmopolitanism of floras and it shows further the part played by isolation in evolution, also indicated by the abundance of monotypic genera in the Orient where the tropical area is so much broken. Not a single species or genus is common to the two hemispheres and even the tribes are almost all either oriental or occidental.

Regarding the origin of the palms most students regard the Pandanacer (screw pines) as their probable ancestral stock and while the latter family is entirely oriental at the present time this was not true in the Tertiary, and it is perhaps significant that the existing genus Phytclephas which is regarded as intermediate between the Pandanacere and the Arecacere is exclusively American, and that genera now exclusively oriental like Nipa and Phœnix are represented in the American Tertiary (Nipa in the Wilcox and Phoni.r in the Vicksburg). There is no warrant for asserting that palms are of occidental origin, at the same time their oriental origin is equally difficult of proof and what we know of their geologic history conclusively shows the inadequacy of the existing distribution in a discussion of their phylogeny.

The three Wilcox species of palms comprise a fan palm and two feather palms. The Chamadorca leaves represent a small palm whose numerous modern allies are confined to America, being richest 
in species in the humid montainus regions of Central America. It is not a corstal form and is nut found in association with the typical Wilcux strand flura, occurring only in the basal Wilcos of Choctaw County, Missisipli, and at the base of the transgressing Lpper Wilcox deposits in Saline County, Arkansas. Its rarity and occurrence in basal beds would seem to indicate that its area of growth was inland and only reached in these two cases by the landward migration of the strand line. The Sulalites, which I have compared with the existing Sabal palmetto, is common everywhere from the base to the top of the Wilcox. It is distinctly a coastal type, rather of the lagoons, bayous and estuaries than of the strand. This is indicated by the fragmentary nature of the remains at very many localities and the occurrence of innumerable complete specimens at other localities as for example at Oxford, Missisippi, where the presence of unios and the local unconformities indicate estuary conditions.

The Nipa palm found in the Upper Wilcox is clearly an inhabitant of mully ticlal shores so that it would naturally be expecter in the laminaterl clays of the Lpper Wilcox. Its single modern representative is tolerant of water of consilerable salinity and is a menber of the mangrove association of the () rient. It shows many points of affinity with the I'andanacex and has never before been found in the Tlestern Ifemisphere. Like so many forms which are strictly oriental in the existing flora such as Cinnanomum, Artocarpus, Phornix. etc. it enjoyer a cosmopolitan range during at least the earlier half of the Tertiary period.

A somewhat full account of Nipa has been recently published by $\mathrm{me}^{9}$ and need not be repeated in the present connection.

The single species of Camna of the Wilcox represents a strictly hygrophilous type which is confined to . America in the existing flora. It is an inlabitant of estuary and river swannps near the coast, and that the Wilcos species inhahited a similar situation is inlicated hy its restricted occurrence and its association with Sabalites near the mouth of a Wilerix river. which on other grounds is known to have been present in Lafayette County, Mississippi.

The Dicotylerlonat of the Wilenx as might be expected are largely chorifetalous forms since there are over 2,50 species of Choripetalie

- Berry, E. WV., Am. Jour. Sci. (IV.), Vol. 37, pp. 57-60, Fig. I, I9I4. 
(Archichlamyder) and only 35 species of Gamopetalæ (Sympetalx). At the same time the representation of Gamopetalæ is really much larger than might be expected thus early in the Eocene and many families often thought to be relatively more modern have been found to be represented.

The following orders of Choripetalæ are not represented in the IVilcox flora: Casuarinales, Piperales, Salicales, Balanopsidales, Leitneriales, Santalales, Sarraceniales and Opuntiales. The absence of the Balanopsidales, Sarraceniales and Opuntiales is not remarkable since they are all specialized types and the rather uniform habitats of the cacti and their relatively modern erolution both conspire to eliminate them from Eocene coastal floras. The presence of the primitive Casuarinales and Piperales might be expected especially since there is a well marked Piper-like form in the Upper Cretaceous of Alabama. The Salicales while prevailingly temperate forms are abundantly represented in the Upper Cretaceous floras of the embayment area and the Santalales have also been recorded from the American Upper Cretaceous and are present in the European Tertiary.

Those alliances of Gamopetalæ which are not present in the Wil$\operatorname{cox}$ to be enumerated presently are mainly the great modern and temperate zone groups. For example there are no Wilcox species of Ericales, Labiatæ, Convolvulacex, Bignoniaceæ. Scrophulariaceæ, Plantaginales, Valerianales or Campanulales, this proving not only the essential modernness of the evolution of the Compositæ ${ }^{10}$ but firmly establishing the thesis that the IVilcox flora is a subtropical and not a temperate flora.

The following are the larger families in the Wilcox flora: The Lauracere with 30 species, Cresalpiniacex with 26, Moraceæ with 23 , Papilionacere with 22, Rhamnacere with. I4, Sapindacere with I3, Sapotacex with 12, Myrtacere and Mimosacex each with II, Combretacex and Anacardiacex each with 9, Juglandacere with 8, Celastracex with 7 , and the Proteaceæ and Apocynacex each with 6.

The largest single genus is Ficus with I8 species, then comes Cassia with 12, Sapindus with 9, Gleditsiophyllum with 8, Oreo-

10 The fruit described as Carpolithus hyoseritiformis is probably referable to the Compositx. 
daplme, Sophora and Anacardites each with 7, Cinnamomum, Nectandra, Rhammus, Myrcia and Bumelia each with 6, and Celastrus, Dillenites, and Apocynophyllum each with 5. Ten species are referred to the form-erenus (arpolithus and this number could readily be greatly increased if all the minlentified seeds were named and described.

The amentiferous families, in accordance with their Lper Cretacenus deployment and their undoubted primitive and not reduced character, are represented in the Wilcox flora by fourteen species, a number of which are individually abundant.

The Juglandales ${ }^{11}$ are represented in the Wilcox by three species of Juglans only one of which, Juglans Schimperi, is at all common; hy a doubtfully determined species of Iticoria; by three well-marked species of Engclhardtia and by an extinct type, Paraengelhardtia, of a habit similar to that of Engelhardtia.

The genus Juglans is one of the earliest of the still existing dicotyledonous genera to appear in the fossil record and it is continuously represented in fossil floras from the Mid-Cretaceous to the present. There are about 25 Eocene species of Walnut and they range during that period from the Gulf region to Alaska and Greenland, and are also present in the tropical forests of the Egyptian Faym in the early Oligocene. The outlying existing species in the Viest Indies and under the equator in South America prove that in spite of the northward range of the Asiatic species in Manchuria and of some of the North American species into New England and southern Ontario, its progenitors were at least subtropical types, a fact corroborated by their foliar character since it is a well-known fact that compound leares indicate tropical ancestry, and this is abundantly proven in the case of Jugians by its associates in the fossil floras where it has been found represented.

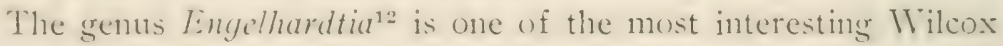
genera. In the first place the illentification of its leaves is corroborated by two varieties of characteristic winged fruits.

The genus was described by Leschen in ${ }_{1} 8_{25}$ and contains about

${ }^{11}$ See Berry, E. W., "Notes on the Geological History of the Walnuts and Hickories," Plant Woirld, Vol. 15, 1912, pp. 225-240.

12 See Berry, E. W., Am. Jour. Sci. (IV.), Vol. 3I, I9II, pp. 49I-496; Plant World, Vol. 15, 1912, pp. 234-238, Figs. 3, 4. 
ten species of the southeastern Asiatic area. These range from the northwestern Himalayan region, where they extend a short distance north of the Tropic of Cancer, through farther India and Burma to Java and the Philippines. The pistillate flowers are small and are grouped in paniculate spikes. They develop into small drupe-like fruits, each of which is connate at the base to a large expanded trialate involucre.

A single little known species, rarely represented in even the larger herbaria, occurs in Central America and is the type and only species of the genus Oreomumnea of Oersted. This is much more restricted in its range than are its kin beyond the Pacific. Oreomunnea is very close to Engelhardtia, and for the purposes of the paleobotanist the two may be considered as identical since they represent the but slightly modified descendants of a common ancestry which was of cosmopolitan distribution during the early Tertiary. The present isolation of Oreomunnea furnishes a striking illustration of the enormous changes which have taken place in the flora of the world in the relatively short time, geologically speaking, that has elapsed since the dawn of the Tertiary.

The principle has frequently been enunciated that when closely related forms are found in the existing flora of the world, restricted in range and isolated from their nearest relatives, or when other existing genera are monotypic, it is quite safe to predict an interesting and extended geological history. Engelhardtia proves to be another illustration of this principle, for its peculiar three-winged fruits have been known in the fossil state for almost a century. They were long unrecognized, however, and the earlier students who described them compared them with the somewhat similar winged fruits of the genus Carpinus (Betulacex). With the botanical exploration of distant lands in the early part of the nineteenth century, specimens of Engclhardtia began to be represented in the larger European herbaria, and Baron Ettingshausen, that most sagacious of paleobotanists, as long ago as $185 \mathrm{I}$ pointed out that certain supposed species of Carpinus were really fruits of Engelhardtia. He returned to the subject in 1858 without, however, actually changing the names of any of the supposed species of Carpinus nor does he seem to have been aware of the existence of a living species of Engelhardtia (Oreomunnea) in Central America. 
Since Ettingshausen's annonncement a dozen or more fossil species have been described. The oldest known European form occurs in the fower Oligocene (Sannoisian) of France and the species become increasingly abundant throughout southern Europe, especially: toward the close of the Oligocene and the dawn of the Miocene, Saporta stating that the slabs from the leaf-beds at. Irmissan in southeastem Erance are thickly strewn with their peculiar fruits. Fossil forms continue in Europe throughout the Niocene and Pliocene and specimens of late Miocene or early Pliocene age are recorded from Spain, France, Italy, Croatia, and Hungary.

The Wilcox species are somewhat older than any of the known European forms

The existing Engelhardtias are upland forms and this may possibly have been their habitat in Wilcox times although their abundance at different localities along the Wilcox coast would seem to indicate that this was not the case.

The genus Paracngclhardtia, which is a mique type confined to a single locality in the Wilcox, is clearly allied to Engclhardtia, as I have shown in the systematic chapter. It seems probable that it represents a survival of the ancestral stock from which Engclhardtia was derived since its fruits are more primitive and indicate ancestral forms with smaller bracts comparable with the bracts of Juylans or Hicoria which in the course of time became accrescent and subsequently (lecply trilobate. The primitive character of Paracngclharltia and the presence of true Engelhardtias in the Wilcox so much earlier than their first occurrence in Europe suggests that America was the original home of the Engclhardtia stock, although this supposition camnot be verified or disproved until a Tertiary paleobotanical record for the continent of Asia is available.

The Myricales contains but two species of Myrica in the IVilens flora. Myrica is a very old generic type with a large number of fossil species ranging from the Mirldle Cretacens to the present. The existing species are relatively few in number and widely scattered geomraphically and represent survivors from a Tertiary cosmo-

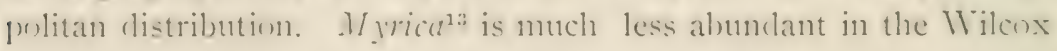

${ }_{13}$ The allied and monotypic genus Comptonia which by some students is included in Myrica has an extended geologic history which has been discussed by Lerry, Amer. Nat., Vol. 40, I906, pp. 485-520, pl. I-4. 
than in the European Tertiary, although it was present in the embayment area in the late Upper Cretaceous (Ripley formation of Tennessee). Its meager representation in the Wilcox time may be due to the more tropical climate conditions. The modern Myricas are temperate and subtropical and a number of the species are coastal forms of either swamps or sand dunes. Myrica clcanoides was evidently a coastal form and so was Myrica wilcoxensis. The latter is very similar to the existing Myrica cerifera which ranges from New Jersey to Texas and is also found on the Bermudas and Bahamas. It is most abundant and vigorous in the sandy swamps along the south Atlantic and Gulf coasts and its habitat may be compared with that of Myrica wilcoxensis. The latter seems to be the ancestral stock of a very similar species which occurs along the Middle Eocene (Claiborne) coast of the embayment.

The order Fagales, which includes such important timber trees of the temperate zone, is comprised by the two families Betulacere and Fagacere, together containing about 450 existing species, of which three fourths belong to the Fagacex. Only the latter family is represented in the IVilcox although the Betulacea are characteristically developed in the Upper Cretaceous of North America.

The family is unrepresented in the IVilcox flora probably because the climate was too warm and this reason may also account for the absence of true oaks since the Fagacere are represented in the Wilcox flora by only the genus Dryophyllum with four rather widespread and often common species.

The genus Dryoplyllum is of worldwide distribution and consistently uniform characters in the various horizons of the late Cretaceous and early Eocene from the Senonian to the Ypresian stages. It especially characterizes the dawn of the Eocene and represents the ancestral stock from which the genera Castanea, Castanopsis, Pasania and Quercus took their origin, although this origin was in the late Cretaceous. As might be expected Dryophyllum has long since become extinct. The IVilcox species were apparently strand types as were also the numerous species enumerated by Debey, the describer of the genus, from the sandy shores of the Upper Cretaccous sea of Rhenish Prussia. Dryophyllum is abunclant in the Montian of Belgium and in the littoral sands of Ostricourt and Bellet in 
France. In the systematic chapter detailed comparisons are made hetween the II ilcox and the foreign species, which show a striking parallelism.

The Urticales includes the families Ulmacer, Moraceæ and Urticalcese together containing about I, foo existing species. The Urticacese are largely herbaceous forms and the Ulmacere are mostly extratropical.

The Ulmacex comprise thirteen genera and about I 40 existing species, widely distributed in temperate and tropical regions. A single species of Planera lescribed originally by Newberry from the Western Eocene is doubtfully identified from the IVilcox. The genus is monotypic in the existing flora and confined to wet swampy situations in the warm temperate region of southeastern North America. Its geologic history goes back to the Upper Cretaceous at which time species have been recognized along the Atlantic coast from North Carolina northward. Thus there is no reason why it should not have been present in the early Tertiary of the embayment unless it be argued that the climate was too warm.

The Moracex, by far the largest family of the order Urticales and the only one certainly represented in the Wilcox flora, contains between 900 and 1.000 existing species segregated among about 55 genera, of which the genus Ficus is by far the largest, including about 60 per cent. of the existing species of the family. The Moracee are distinctly tropical and warm temperate types and are most abundant in the oriental tropics, although the dominant genus Ficus is willespread and the family is also largely represented in the South American tropics.

There are at least 18 monotypic genera of which one is North American, four South American, four African, and nine Australian. No single tribe is confined to a single continental area and all show apparent anomalies of distribution due to our lack of knowledge of their gerlogic history. The genera Ficus, - Irtocarpus and Artocarpidium go back to the hase of the Lpper Cretacenus and numerous additional genera appear in the Eocene.

There are 2.3 species of Moracee in the Wilcox flora. The genus Artocarpus is represented by three well-marked species. In the existing flora the two score known species of drtocarpus are confined 
to the southeastern Asiatic region ${ }^{1+}$ although some of them are cultivated in all tropical countries. The tribe Euartocarpece of which Artocarpus is the largest existing genus, have, however, five of their genera confined to Central and South America, one confined to tropical West Africa, two confined to the southeastern Asiatic region, one to Borneo and one ranging from Japan to Australia. While the geologic history of Artocarpus is only imperfectly known at least I5 different fossil species have been described. The oldest is a wellmarked form based on characteristic leaves and parts of the fruit which show the typical surface features. It has been fully described by Nathorst ${ }^{15}$ and comes from the Atane beds (Cenomanian) of West Greenland. Slightly younger is a less well-defined form recorded from the Emscherian of Westphalia, and the somewhat doubtful genus Artocarpophyllum of Dawson from the Lpper Cretaceous of Vancouver Island. Another species is recorded from the Laramie formation and the gentus is widely distributed in the basal Eocene of North America. It continues in the Mississippi Gulf region until the close of the Oligocene, the last recorded occurrence being in the Alum Bluff sands at Alum Bluff on the Apalachicola River. On the Pacific coast it is found in deposits in California and Oregon which are referred to the Miocene. In the European area it occurs in the Tongrian of France, the Tortonian of Baden, the Pontian of France and Italy and the Pliocene of Italy. It is present in both the Pliocene and Pleistocene of the island of Java.

Artocarpus is said to be represented by petrified wood in the Oligocene of the island of Antigua and it was evidently a member of the American flora from the Upper Cretaceous until late in the Tertiary, although like the genera Cinnamomum, Nipa, Phonir, etc., it is not represented in post-Pleistocene American floras. An extinct genus related to Artocarpus and named Artocarpoides by Saporta, who described several species from the Paleocene of France, is represented by a single Wilcox species.

${ }^{14}$ It is found throughout Oceanica and was present in the Hawaiian and Marquesas when they were first visited by Europeans. It was introduced into the West Indies in 1793.

${ }^{15}$ Nathorst, Kgl. Sienska Vetens-Akad. Handl., Bd. 24, No. I, I89o, то pp., I pl. 
The genus Cecropia with about 40 existing species confined to the tropics of South America has two species in the Aquitanian of Bohemia and the Midway and Wilcox form described as linus s]). is very probably a representative of this genus.

The genus Pscudolmedia, with five existing species in the American tropics, has a well marked species in the Wilcox flora. As far as I know it has not heretofore been recorded in the fossil state although it is probable that some of the very numerous fossil species of Ficus may represent Pseudolmedia.

The genus Ficus is represented by numerous species in the Wilcox flora no less than eighteen having been described and a number of these are individually abundant. They include the narrow lanceeolate forms of the Ficus elastica type, with close-set laterals, as well as open-reined lanceolate forms, and the shorter and broader palmately veined forms. None are lobate or have toother margins. Ficus was evidently much more abundant and varied along the IIilcox coast than it is today throughout the West Indies and more nearly comparable in this respect with the display of figs in the East Indies or in tropical South America.

The number of fossil forms that have been referred to Ficus are very numerous, numbering perhaps 300 species. None are certainly known from the Lower Cretaceous, the genus Ficophyllum ${ }^{16}$ being entirely doulut ful. In the Lpper Cretaceons, however, Ficus is very widesprearl and abunlant, seemingly indicating a Lower Cretacents ancestry as yet unknown. The Cenomanian stage has furnished 3 species in Greenland, 6 along the Atlantic Coast and 24 in the interior of North America, as well as II in Saxony, Bohemia and Moravia. The succecling Turonian stage furnishes + species in Bohemia and the Tyrol, and several in North America (Tuscaloosa, Magothy, Ilack (reck, Eutaw formations). Later Lpper Cretacenus horizons have abunclant species of Ficus every where throughout . Vorth - Inerica and Europe as well as in Greenland, Anstralia and Xew Zealanel. and this cosmopolitanism continues throughout the Tertiary, there being alout so Eocene species, about Go Oligocene species, on Mincene species and 20 Fliocene species. Ifrica is adrled to the recoml in the basal Oligocene, and Asia in the Miocene.

10 See Berry, E. W., Md. Geol. Surv., Lower Cret., igri, pp. 502-506. 
The fossil records will have to be much more complete before the original center of radiation of the Moracere can be determined, the present brief sketch can be said to merely indicate that not only Ficus, but other genera like - Artocarpus that are entirely oriental in the present, were normal elements in North America floras, from the time of the molemization of these floras at the beginning of the Upper Cretaceous onward. Along our east coast, they apparently became restricted in their range at the dawn of the Miocene and they apparently never after became as important in southeastern North America as they had been, or as they are in the recent flora of the Orient.

The order Proteales includes the single family Proteaceæ with about one thousand existing species. They include the prominent arborescent forms of Choripetalæ in the Southern Hemisphere, to which region all but the four genera Roupala, Protea, Leucospermum and Helicia are confined. They are usually considered as Australian types, in fact the majority of the genera and species are confined to that continent, nevertheless there are four genera in South America together containing over fifty existing species, and there are several genera peculiar to the African flora; and the genus Helicia is predominantly Asiatic.

The geologic history of the Proteaceæ is perhaps one of the most striking instances that paleobotany affords of the great difference in geographical distribution in former ages from what could possibly be inferrel from a study of the present geographical distribution of the memlers of this family, although there are some significant features in the distribution of the recent forms that will be alluded to in a subsequent paragraph.

The discovery of fossil forms of Proteaceæ in the Tertiary deposits of Europe was the inspiration of a considerable literature ${ }^{17}$ and was the occasion of a rather acrimonious controversy regarding their botanical affinity: This is well illustrated in the dissenting opinions cxpressed by the botanists Ilooker and Bentham who both regarded fossil leaves as unleterminalule. Starting with this apriori principle it is difficult to see how they could arrive at any other conclusion.

12 See the writings of Unger, Heer, Ettingshausen, Schimper, Schenk and Saporta. 
The most expeclitious refutation of their opinion is furnished by the present distrilution of some of the genera, $c . g$., the genus Roupala has 36 species in tropical America, 2 in New Caledonia and $I$ in ()uechsland: the genus Embothrium has four. Andean species and one in . Instralia: the genus Lomatia has 3 species in Chile, $t$ in Australia and 2 in Tasmania. It follows unless one is prepared to subscribe to the doctrine of special creation for each continent or to the independent evolution on separate continents of different species of the same genus, that during their geologic history these genera must have ranged over intervening areas, so that if the Cretaceous and Tertiary plants of the northern hemisphere with fruits and leaves of the l'roteacex are not related to the genera that they resemble must. then forms with leaves and fruit resembling those of other families must be fossil Proteaceæ, which ought to seem absurd, even to an English botanist. As a matter of fact, while exception may justly be taken to some determinations of L'nger, Ettingshatsen and Heer, they in no wise affect the main body of facts and there is so much collateral evidence furnished for example by the geologic history of the Aratcarian conifers, and the history of the Proteaces is so sinilar to that of the Myrtacex and Leguminose-the two other great families of the existing Australian flora, that the eridence secms conclusive.

Turning now to the fossil record those who follow the opinion of Hooker or Bentham will see how vast and substantial are the supposed illusions of the paleobotanists. In addition to the two extinct genera in the IVilcox flora I have fossil records of 32 genera of Proteacere, although this is artificially enlarged by the joint usage. according to taste, of names like Dryandra and Dryandroides, Banksia and Banksites, etc. A brief consideration of these genera with fossil representatives will prove valuable. ${ }^{18}$

The genus Protea Linné, from which the family takes its name, has about fo existing species occupying disconnecterl areas in (cntral and South Africa. To it have been referred a middle Cretaceous species from Saxony: 3 Aquitanian species from l'russia, Ionhemia and Greece; I species from the Burdigalian of Italy; I from

${ }^{18}$ This list is not complete but sufficiently so for the purpose of this discussion. 
the Helvetian of Switzerland and one from the Messinian of Italy. Allied to Protea but possibly more generalized is the genus Proteoides of Heer. This has several Tertiary species and a considerable number of Upper Cretaceous species ( 15 ). There are two each in the Cenomanian of Bohemia and Lesina, two in the Atane beds of Greenland, three in the Dakota sandstone of North America, one in the Tuscaloosa formation of Alabama, one in the Middendorf beds of South Carolina, one in the Cretaceous of Australia, two in the Vancouver Island Cretaceous and one in the Senonian of Saxony.

The genus Proteophyllum Velenovsky ${ }^{19}$ a still more generalized proteaceous type has seven species (Saporta, 1894). in the Albian (Vraconian) of Portugal and 8 species in the Perucer beds (Cenomanian) of Bohemia. Another generalized type is Proteopsis Velenovsky with a single species in the Cenomanian of Bohemia. The genus Proteaphyllum of Fontaine containing 2 species in the Patuxent fomation (Neocomian) of Virginia I regard as entirely worthless. ${ }^{20}$ The genus Conarrhenes Labill with one existing species in Tasmania has a single species based on both foliage and fruit in the Miocene of Carniola according to a determination of Ettingshausen's which may well be viewed with suspicion. The genus Conospermum Smith with about 33 existing species in Australia has two fossil species in the Oligocene of Styria and one in the Miocene of Carniola, while the somewhat less definite genus Conospermites (Ettingshausen, 1867) has a fossil species in the Upper Cretaceous of Australia and one in the Cenomanian of Saxony and Bohemia. ${ }^{21}$

The genus Helicia Lour. is of especial interest since it is found farther north in the existing flora than any other member of the family. There are about 25 modern forms, mostly Indomalayan, but a few still survive in or have recently spread to Australia. The fossil record includes a species in the Oligocene of Styria and another in the Pliocene of Italy. The gents Lambertia Smith with 8 existing Australian species has a single fossil species in the Miocene of Carniola. The genus Hakea Schrad. with roo recent Australian

19 Velenovsky, Kvetena českého cenomanu, I889, p. I8.

20 See Berry, Md. Geol. Surv., Lower Cretaceous, I9I I, pp. 494-499.

21 I regard Fontaine's determination of a species in the Lower Cretaccous of Virginia as worthless. 
species has eleren fossil species in the Oligocene of Europe; in France, the Tyrol, Saxony and Greece; and no less than ry Miocene species in France, Italy, Switzerland, Paden, Hesse, Prussia, Dohemia, Austria, Styria, Croatia and Hungary.

The genus Knightia R. lirown with a modern species in Australia and $2 \mathrm{in} \mathrm{New}$ Caledonia has a fossil form in the Eocene of Australia and another in Graham Land"2 in beds regarded as Oligocene. The allied genus Knightites Saporta has two species in the Sannoisian of France.

The remarkable genus Lomatia, previously mentioned, has four existing species in Australia, 2 in Tasmania and 3 in Chile. As might be expected from their modern isolated occurrences there are over 30 fossil species based in some cases on associated leaves and fruits. The oldest of these are two (perhaps wrongly identified) species in the Dakota Sandstone. Eocene records include the Green River shales of North America, a Ypresian species from the south of England, an Italian species, five Australian and one Tasmanian species. There are about a dozen Oligocene species, some of which are very characteristic. They occur in the Tyrol, Saxony, Baltic Prussia and Styria, and the relatively large number of four are recorded by Dusén from Graham Land (Antarctica). There are also about a dozen Miocene species recorded from such separated areas as Colorado, Switzerland and Carniola. The wonderfully preserved leaves in the roleanic ash beds at Florissant, Colorado, from which seven forms have been described, the only known. Miocene occurrence of Lomatia in North America, are alone sufficient to confound the sceptics.

The allied genus Lomatites Saporta has a Cenomanian species in Saxony and five or six Oligocene species in France. The genus Stcnocarpus R. Brown, with I I existing species in New Caledonia and 3 adclitional ranging from North Australia to New South Wales, has a single fossil species in the Oligocene of Saxony.

The genus Persoonia Smith has 60 existing species in Australia and one in New Zealand. The fossil record inclucles two widely distributed species in the Upper Cretaceous of North America; one

22 Dusén, Wiss. Ergeb. Schwed. Südpolar. Exped., IgoI-03, Bd. 3, Lief. 3. P. 7, Pl. I, Figs. 7, 9, II, 1908 . 
in the English Eocene; four in the Oligocene of Tyrol, Saxony, Styria and Greece; ten in the Miocene of France, Italy, Switzerland, Baden, Bohemia, Styria, Croatia, Carniola and Slavonia. A large number of these fossil forms of Persoonia are not especially convicing but certainly the three European species Persoonia cuspidata, daphnes, and Myrtillus of Ettingshausen ${ }^{23}$ which have the leaves associated with characteristic fruits are above suspicion.

Bowerbank in his classic study of the pyritized fruits and seeds from the Island of Sheppey established a genus which he called Petrophiloides from its resemblance to the genus Petrophila R. Brown which has about 35 existing species in Australia, the majority of which are confined to West Australia. Bowerbank described several species one of which was shown by Starkie Gardner to be an Alnus fruit and others have been referred to Sequoia. Ettingshausen ${ }^{24}$ in the study of the Sheppey fruits after careful comparisons retained three English Eocene species and the genus has also been recognized in the Sannoisian of Dalmatia and Styria.

The genus Lellcadendrites was established by Saporta for a Sannoisian species of southeastern France from its resemblance to Leucadendron Herm., which has upwards of 70 existing species in South Africa.

The genus Greillea R. Brown has 56 existing species confined to Australia. The fossil record includes a Cretaceous species in Australia; two Cenomanian species in Bohemia (Grevilleophyllum Velenorsky); three Eocene species in England, France and Italy; twelve Oligocene species mostly in southern France but also represented in Saxony, Tyrol, Bohemia, Styria and Greece; and twelve Miocene species in France, Switzerland, Bohemia and Croatia.

The genus Embothrium Forst., already alluded to, has four existing species in South America which range from Chile to the Straits of Magellan, and a fifth species in Australia. This widely separated occurrence is explained when the fossil record is combined with the occurrences referred to Embothrites, Embothriopsis and Embothriophillum. To Embothrium are referred 8 Oligocene spe-

${ }^{23}$ Ettingshausen, Sitz. K. Akad. Wiss., Wien, Bd. 7, I851, pp. 718-719, Pl. 30, Figs, 6-14.

24 Ettingshausen, Proc, Roy. Soc, L.ond., Vol. 29, I879, p. 394.

PROC. AMER. PHIL. SOC., LIII. 214 K, PRINTED JULY II, I9I 4. 
cies of Styria and Greece and 4 Miocene species of Baden, Styria, Croatia and I Iungary. To Embothriopsis Ifollick a single species from the Long Island Middle Cretaceous is referred.

Embothriopliyllum is used by Dusén for a single species from the supposed Oligocene of Graham Land. The genus Embothrites Lnger has a cloubtutul species in the Dakota Sandstone; six Oligocene species in France, Tyrol, Styria, Carniola and Greece; and 3 Miocene species in Croatia and Bohemia.

The genus Dryandra $\mathrm{R}$. Brown has about 50 existing species in Australia. The fossil forms have occasioned much discussion and have been referred back and forth between this genus and Comptoniu and Myrica. The forms retained in Dryandra include a Cenomanian species in Thohemia and Moravia; an Eocene species in France: two Encene species in Australia and an Oligocene species in Greece. The allied forms referred to the genus Dryandroides Unger include 5 Upper Cretaceous species in Europe and North America: an Eocene species in Tasmania; 4 Oligocene species in Italy, Tyrol, Saxony, Styria and Greece; and a Miocene species in Bohemia.

The allied genus Banksia Linné fil., also confined to Australia in the existing flora, has 7 Tpper Cretaceous species-t A Instralian anel 3 in the North Temperate zone, ten Eocene species, of which 7 are Australian, I Alaskan (?) and 2 English; twelve ()ligocene specie: widely distributed in Europe; if Miocene species equally widesprearl in Europe; and a Pliocene species in Italy. Three especially well markerl species from the IVilcox have been referred to this genus.

The allied genus Banksites Saporta has a Cenomanian species in Tohemia and various Tertiary records from Europe hopelessly entangled in the literature with Banksia, Dryandra and Dryandroides. The genus Roupula Aulblet (Rhopula), whose peculiarly isolated outliers in (Uneensland and New Caledonia have already leen mentioned. is common in northern South America, extending northward to Guatemala. Fossil forms are recorded from the Cenomanian of Saxrmy, from the Eocene of Australia and from the Aquitanian of Switzerland. In addition Saporta described a Rhopalospermitis irom the lower (oligocene of France and a species of Rhopulophyllum has been described from the f pree Cretacenus of Australia and a secont from the Miocene of Styria. 
The geological history sketched in the preceding paragraphs is necessarily fragmentary, nevertheless I think the data are sufficient after excluding doubtful cleterminations to show that the family had its origin in the northern hemisphere, making its first appearance in the fossil record at the close of the Lower Cretaceous, becoming practically cosmopolitan during the L'pper Cretaceous at which time it reached the Australian region from southeastern Asia. New Zealand must have already been segregated but not the land mass now represented by New Caledonia. During the early half of the Tertiary Africa and southern Europe were essentially a single floral province while in the Western Hemisphere the Proteaceæ ranged from the United States through South America and an unknown distance across Antarctica. Concomitant with the continent building and the consequent climatic changes of the Miocene the area of distribution commenced that shrinking which culminated during the Pleistocene, leaving the stranded remnants of the stock in their present widely separated quarters of the southern hemisphere. Not all the modern genera took part in this history since the local peculiarities of poor soil and rigorous climate combined with relative freedom from ontside competition were the factors that stimulated a Tertiary evolution of forms in Australia in exactly the same manner as the peculiar Australian genera of Myrtaceæ and Leguminosæ were evolved.

The Wilcox species of Proteacex are six in number and are distributed in four genera, in addition to which a probable Banksia fruit is retained in Carpolithus. These genera are Palcoodendron, Proteoides, Knightiophyllum and Banksia. The genus Polcodendron, not mentioned in the preceding paragraphs, was proposed by Saporta for small entire coriaceous leaves from the Sannoisian of southern France and is an entirely extinct type, sparingly represented in the IVilcox by a single species. The genus Protcoides was established by IIcer for generalized proteaceous types which are well represented in the Upper Cretaceous floras of the embayment area as well as elsewhere. It is represented in the Wilcox by a single well-marked species confined to the Mirldle and Lpper beds. The genus Knightioply yllum is proposerl here for the first time for a well-marked long petioled, acpuiline-toothed, coriaceous form of common occurrence at 
I'eryear. It is named from its resemblance to the genus Knightic R. Pirown, a genus of few existing species confined to the Australian region but apparently represented in Europe during the Tertiary as has already been indicated.

The genus Banksia, with three IVilcox species, two of which are particularly well marled and a probal)le fruit, Carpolithus proteoides, is confined in the existing flora to the Australian region with about 50 species. The other genus of the tribe Banksiee is Dryandra $\mathrm{R}$ Jirun also with about 50 existing species confined to the Australian region. It is much like Banksia in its foliar characters. Both genera are found in abundance in the European Tertiary and undeubtedly enjoyed a more or less cosmopolitan range during the early Tertiary. Their ancestors probably entered the Australian region during the Lper Cretaceous before that country had become entirely separated from Asia, becoming adapted to the peculiar soils and climate of Australia, while the stock in the northern hemisphere appears to have been unable to stand the climatic changes and Tertiary competition and thus became extinct.

The Aristolochiales is placed by some students among the Gamopetale. It includes besides the Aristolochiacex, the two parasitic families, the Raffleisiaces and Hydneracert, altogether containing about 235 existing species, of which 205 belong to the Aristolochiacer, the only family of this order represented in the IVilcox flora. The genus. Aristolochial, to which a typical fruit from the IVilcox is referred, is found in the American Lper Cretaceous and in both Furope and America during the Tertiary. There are about iso existing species all perennial herbs or climbing vines and widely distributed in both tropical and temperate regions, about ten species being found within the United States.

The rriler I'olygonales includes the single family. Tolygonaces with about sno existing species segregated in about 30 genera, wiclely. distributed. They embrace herbs, shrubs, vines and trees, with mosly cyclic flowers, and in their morphological features show some cridences of transition between the previous chripetalous alliances and the Chenoprodiales. The geologic history of the family is practically unlowwn and it would seem that a large part of the specific variation, particular!y of the temperate herhacens forms. was rela- 
tively modern. The family is represented in the Wilcox by the single genus Coccolobis with two species which appear to be the Eocene prototypes of the only two existing arborescent species of Polygonaceæ that reach the United States (the sea grape and the pigeon plum). The genus Coccolobis has about I 20 existing species all confined to the American tropics and it would appear that it was of American origin. These species range from southern Florida to Mexico, Central America, Brazil and Peru and the majority are coastal forms. The two modern species which are so much like these two ancestral forms in the Wilcox, are strand types found from the Florida keys through the West Indies to the northern coasts of South America, and the conclusion is almost irresistible that the Wilcox forms enjoyed a similar range and an identical habitat.

The Chenopodiales (Centrospermæ of Engler) include ten families culminating in the Caryophyllacex, and containing about 3.500 existing species. They appear illy assorted and show a wide range in floral and other morphological characters. Perhaps a majority are modern types. The single family Nyctaginacex represents this order in the Wilcox.

The Nyctaginacer with about I50 existing species is predominantly American within the limits of the southern Lnited States on the north and Chile and Argentina on the south. The genus Pisonia Plumier, the only genus thus far found in the Wilcox flora, is represented by three well-marked species. It has about 40 existing species chiefly in the American tropics and contains the only arborescent form of the family found within the United States. It has an extended geologic history, well-marked forms being found in the European and American Upper Cretaceous. The Wilcox species were undoubtedly strand types as are so many of the modern species, which inhabit sea beaches, the shores of salt water lagoons and marshes, the scrub of beach ridges and the jungle behind them. In the existing flora it is associated with Pithecolobium, Reynosia, Ictopium, Acacia, Bumclia, Cordia. Coccolobis, Ocotca, Fagara, Mimusops, Conocarpus, Cassia, Eugcnia, Anona, Ficus, etc., exactly as it was during Wilcox time. Species of Pisonia occur in the Upper Cretaceous of the Atlantic Coastal Plain ( Black Creek formation) as well as in the Viddle (Claiborne) and Cpper (Jackson) Eocene. 
The order Ranales appears to me to be a highly unnatural assemblage, which doubtles explains the prolonged discussion and wide range of opinion regarding its true status. As treated in Engler and Prantl it inclules if families with over 4,000 existing species. While a distinct calyx and corolla are the prevailing habit this is combined with such primitive features as apocarpy and hypogYny, and by a we!l marked tendency to indefinite repitition and spiral arrangement of the floral members. I have removed the Lauraceæ which contain if of the existing species to a place in the more evolver order Thymeleales.

The Ranales as a whole show no close filiation with previous alliances. They include forms that are more nearly. Monocotyledons than Dicotyledons (Nymphæaceæ) and numerous botanists (c.g. Wieland. Arler, I Iallier) see in them the logical zenith of evolution of the Mesozoic Cycarlophytes and thus as representing the ancestral stock from which the Angiosperms were descended-apparently a most remarkable feat, except on paper, when any except floral features are taken into account. ${ }^{25}$

Considering as I do that the Ranalian alliance is a plexus containing unrelated elements, any extended consideration of their geologic history would be fruitless. Certain forms are well represented among the oldest known display of Angiosperms in the Nidrlle Cretaceous. Only two Ranalian families are represented in the IVilcox flora and these two are both natural groups closely relater and typically Ranalian. I refer to the families Magnoliacee and Anonacex.

The family Magnoliacee comprises alont 70 existing species segregated into nine or ten genera, by far the largest of which is the genus. Magnolia with abont 2 I species of eastern and southern . Lia southern Mexico and the eastern United States. The family is mainly tropical and the bulk of the existing forms oceur in southcantern . Asia, the magnolias of that region being largely forms of tropical uplands.

There are numerous apparent anomalies in the distribution of the recent forms, thus none are native in Europe, although . Yatmelia per-

${ }^{25}$ For discussion of this theory see recent papers by Wieland, Arber and Parkin, and Hallicr. 
sisted in that region as late in geologic time as the early Pleistocene. Only one genus, Drimy's Förster, occurs in South America or Australasia. There is a singtular pairing of forms in southeastern Asia and southeastern North America. For example Iagnolia has I species in the former region and seven in the latter: Talauma Jussieu has 3 species in farther India and one in the West Indies: Liriodendron Linné has a single species in each: Schizandra Michaux has species in each: Illicium Linné has five species in the former region and two in the latter. The general Michelia Linné ( 13 sp.) and Kadsura Jussieu ( 7 sp.) are confined to the former region and Zygogymum Baillon is confined to the island of New Caledonia. The leaves of all are entire and more or less elliptical with a coriaceous texture, often evergreen, and with a characteristic camptodrome venation. Of the seven species of Magnolia found within the limits of the United States, Magnolia glanca. Linné ranges northward to Massachusetts and Magnolia acuminata Linné to New York and Ontario. About sixty fossil species have been referred to Magnolia. These are largely based upon leaves, although characteristic fruits, and in at least two cases, parts of flowers, have been found at various horizons. Tagnolias are very abundant in both individuals and species in the Middle Cretaceous (Cenomanian-Turonian) especially in North America, where they are found along the Cretaceous Atlantic Coast from Greenland southward to Texas and in equal abundance about the borders of the advancing interior sea represented by the deposits known as the Dakota sandstone. They are much less common in Europe and the genus is either of American or Arctic origin. ${ }^{26}$

The Eocene records include 4 species of the Arctic region and I 3 additional forms largely American, but some few European. The Oligocene, unrepresented in America by plant beds, has several European species toward its close. About eight Miocene species are recorded, of which the majority are American. The Pliocene, also practically unrepresented by plant beds in America, has furnished 5 or 6 European species and one is found in the early Pleistocene of that region. Magnolia seems to have heen very abundant along the

26 Magnolia Delgadoi Saporta, Fl. Foss. Port., p. I94, P1. 35, Fig. 5, I894, recorded from the Albian of Portugal is almost certainly not a Magnolia. 
shores of the extended Mediterranean sea of the Pliocene and to have subsequently been entirely exterminated in that region by the glaciation of the Pleistocene, while surviving in both North America and Asia by reason of the prevailing north and south trend of the of the mountain ranges. Some of the other genera of the Magnoliaceie are represented by scattered fossil species but the record is too incomplete for generalizations. I survey of all the facts leads me to consicler America as probably the original home of Magnolia and despite the massing of the existing forms in the eastern United States and their extension to Arctica in the Eocene, they probably originated in a warm-temperate or subtropical latitude, spread northward across Arctica to Eurasia, were cosmopolitan in the Tertiary, becoming restricted to the southeastern parts of Asia and North America by the aridity accompanying uplift, so well illustrated in the Eocene and later history of the Rocky Mountain and Great Plains province, and were finally killed off in Europe by the Pleistocene glaciation.

Lesquereux referred two forms from the Wilcox of northern Mississippi to Magnolia but these both prove to be species of $T \mathrm{cr}$ minalia as Lesquereux had surmised in his preliminary studies. The genus Magnolia is, however, represented in the Wilcox by two largeleafed species, both of which are common to the basal Eocene of the Rocky Mountain Province. Neither show any close affinity with the antecedent Pper Cretaceous forms which are so common in the embayment area of Alabama and northeastward along the Atlantic Coastal Plain.

The family Anonacex contains about 700 existing species distributed among about 48 genera, only two of which are present in North America. The family is practically confined to the tropics, a single Australian species and the North American genus. A simina with 6 or 7 species being the only conspicuously extratropical forms. The area of maximum representation is southeastern $A$ sia and the adjoining region of Malaysia, for while only í genera are confined to this region it contains over 350 species, and six additional genera (1/Filiusa, L'iraria, P'olyalthia, Orymitra, lyolodorum, and Poporiar) with a total of over 250 species have the bulk of their species in this area. Only a single gentus is confined to Australia and the bulle of the Aus- 
tralian species are to be regarded as migrants from the preceding area. There are upwards of Ioo species and 6 peculiar genera in tropical Africa; and America has about 200 species and 10 peculiar genera. These are all confined to the tropics except for a species of Anona which reaches the coast of peninsular Florida and for the genus Asimina with six or seven species of shrubs and small trees of the south Atlantic and Gulf States. One of these, Asimina triloba Dunal, is hardy as far north as New York and has the distinction of growing the farthest distance from the equator of any existing member of the family. The fossil record of the Anonaceæ is very incomplete, only the genera, Anona Linné and Asimina Adanson being known with certainty. Both of these genera are present in the IVilcox flora.

The genus Anona has from fifteen to twenty fossil species five of which are also represented by seeds. The oldest is a species described from the Dakota sandstone. There is a second species in the late Cretaceous or Early Eocene of the Rocky Mountain province. The flora of the Wilcox affords a glimpse into the true stage of evolution of Tertiary floras in that expanded belt of the American equatorial region which was the center of radiation of so many recent types. There were three exceedingly well marked species of Anona along the IVilcox coast and their leaves are very common at some localities although no seeds have as yet been discovered. I assume that these IVilcox forms had habits similar to those of the majority of the existing species, exemplified by our Florida Anona glabra Linné, or Pond Apple, which frecuents shallow fresh water swamps, low shady hammocks, or stream borders near the coast. Other species occur in the low coppice association or on edges of brackish swamps on the Bahamas. The cultivated species, as for example the American - Inona reticulata Linné which is planted in Guam often spreads naturally along the inner beaches, while attempts to introduce others of the most highly esteemed American species in the Orient have failed. From its prevalence among the existing species the habit of growing in wet shaded soils is evidently an old one, and since the IVilcox Inonas are associated with a strand flora, the assumption that they grew on the inner beaches or the shaded and more swampy edges of lagoons, possesses every degree of probability. 
In the pipe-clays of Mhum lay which were contemporaneous with the Wilcox there are two species of Anona, and Engelhardt has described two species from the Eocene or Oligocene of Chili. The Oligocene record shows a species in France and a second in Saxony: In the Miocene there are two species each in England, Styria and Croatia and one each in Lohemia, Colorado and Transylyania. There is one each in the I'liocene of France and Italy, showing how modern was their extinction in the south of Europe.

The genus Asimina has only four or five recorded fossil species. These are all American except for a form from the Pliocene of Italy which has been referred to this genus, although I suspect that it represents Anona, since I simina appears to have originated and been confined to the Vestern ITemisphere. The oldest known species is based on foliage which is found in the basal Eocene of the Rocky Mountains (Denver formation) and of the embayment (Midway Group). There is a single species based on a seed from the basal Wilcox and no other records except a form close to the modern from the late Miocene of New Jersey (Pridgeton sandstone) and the occurrence of the existing. Asimina triloba Dunal in the interglacial beds of the Don valley in Ontario.

The order Papaverales (Rhoedales of Engler) includes six families-l'apaveracea. Crucifere, Capparidacea, Resedacea, Tovariacee and Moringacese, together containing about 255 genera and 2,200 species. The Papaveracex and Cruciferæ are mostly herbaceons and widely distributed, largely in the North Temperate zone. and they are of relative recent evolution. The Resedacea is a small family largely confined to the Mediterranean region. The Cappariclacee, Tovariacese and Moringacese are mainly tropical, the last two families consisting respectively of a single genus and two species of the Inerican tropics and a single genus and three species, one AfricArabian and two East Indian.

The family. Capparidacex with about 35 genera and 400 existing species is the only ane of the order represented in the Wilcox flora. I majority of the existing species are herbacens and they are found on all the continents in tropical and subtropical regions. Five subfamilies are reconnized. Of these the Cleomodere and Capparidi- 
odex are large and occur on all of the continents, with monotypic genera in North America (Isomeris), South America (Stubelia Atamisquea, Belencita), Africa (Pteropetalum, Cladostemon), and Australia (Rapcria, Apophyllum). The subfamily Dipterygioidex has a single genus with only five or six species of Nubia, Arabia and the Punjal. The subfamily Roydsioldere includes about a dozen species. the genera Roy'dsia and Stirt is being confined to India and the genus Forchhammeria being Mexican. The subfamily Emblingioideæ has only a single genus and species confined to Western Australia. No far-reaching conclusions regarding origin or past history can be deduced from our present knowledge of the geographical distribution of the Capparidacex and the fossil record is so imperfect that very little can be said regarding this history.

The following are the only fossil records known to me: F. von Iiuller has described somewhat uncertainly determined fruits from the Tertiary of Australia as the genera Dieune and Plesiocapparis. The latter has two species and is considered as probably a member of the section Busbeckia of the genus Capparis. Schenk has described the petrified wood of another form from the Tertiary of Egypt under the name Capparidoxylon. The genus Capparis has furnished a well-marked Wilcox species very close to the existing Antillean tree Capparis domingcusis Sprengel. There are about one hundred existing species of Capparis, mostly tropical, and although found in the Eastern Hemisphere the majority occur in the American tropics, especially in Central and South America. The oldest known fossil forms are two species described by me as species of Capparites from the Upper Cretaceous of Alabama (Tuscaloosa formation). In addition to the Wilcox species previously mentioned, Engelhardt has described a Tertiary species from Bolivia. Many years ago Lnger described a third species from the Middle Niocene of Styria but Schimper considers the latter to be a papilionaceous form. While the fossil record of Capparis is so meager such facts as are available would seem to indicate that it originated in the American Lpper Cretaceous. Very many of the modern forms are shruls, or small trees of the strand flora and such is believed to have been the habitat of the Wilcox species. 
The order Rosales includes about eighteen families: with over fourten thousand existing species, the largest families being those of the T.eguminosie, and the Rrsacete, Saxifragacee and Crassulacere. Some members of the alliance are close to the Ranales in their apocarly, hypogyny and the indefinite repetition of certain floral members, and the order culminates in the relatively modern I'apilinnacue. Five families of Rosales are present in the Wilcox flora. Of these the three leguminous families are by far the most abundant.

The family Hamamelidacex consists of about nineteen genera and fifty species. Twelve of the genera are confined to the Asiatic region. One genus is doubtfully confinerl to At1stralia: Three genera are $\mathrm{A}$ frican: and three genera are common to Asia and eastern North America. The family is remarkable in containing no less than nine monotypic genera. A consideration of the existing distribution is not only of exceeding interest but also ennclusive pror $\mathrm{f}$ of an extenrled geologic history. which unfortunately has not yet been unravelled. Since the group is scarcely if at all represented in the existing flora of Australia or in its fosil flora, its present range over Asia wruld seem to have been accomplished after the land connection with Australia had been interrupted. As the only known Cretaceous fossil forms are from North America there is a probability that the group had its origin in the North - Inerican region. The fossil species are not numerous enough, however, for definite conclusions on this point.

The genus Hamamolis and its generalized fosil type Hamamelites. Saporta have five species in the Dakota sandstone, one of which occurs in the Atlantic coast Cpper Cretacents I Middendor f berls of South (arolina) and another is loultfully representerl in the supposed Upper Cretaceous of Argentina (Kurtz). There are two I'alerene species in France and lielgitum, and Conwentz hats describerl characteristic fowers preserved in periection in the Ialtic Amber (Sannoisian) as Hamamclidanthium.

The genus Parrotia, with a single existing species of northern I'er-ia and the Cancasus, has three species in the Dakota samilotme:

${ }^{27}$ The family Platanacex, which by the majority of students is referred to the Rosales, I regard as the sole survivor of an independent order, the Platanales, closely related to the Urticales. 
one species in the Wilcox and Fort Union: two in the Oligocene of Europe: and two in the Niocene of Spitzbergen, Spain, France, Silesia, Austria, and Hungary. The distribution of Parrotia in the past as far as it is known confirms the evidence derived from Hammamelis for a North American origin for the family.

The third genus with a geological history is Liquaiambar, in which upwards of twenty fossil species have been described. The oldest known forms occur in the Eocene at such widely separated points as Alaska, Oregon, Greenland and France. There are two species in the Oligocene of Asia and Europe. There are nine or ten Miocene species represented throughout Europe and North America (New Jersey to Oregon) and in eastern Asia. Three Pliocene species are represented in Spain, France, Italy, Germany, Austria, Styria and Slavonia. Typical fruits preserved in the Upper Pliocene of Germany show how late the genus flourished in central and southern Europe. Felix has described the petrified wood of Liquidambaro.rylon from the Tertiary of Hungary. The existing Liquidambar styraciflua is found in the Pleistocene of West Virginia, North Carolina and Alabama and the eastern Asiatic species L. formosana occurs in the Pleistocene of Japan. The genus Corylopsis also occurs in the post-Miocene deposits of Japan.

The family Rosacec includes about 90 genera and over I,300 existing species, widely distributed and mostly in temperate regions. Some of the genera like Cratagus seem to be undergoing saltation at the present time and hundreds of supposed species have been described in the past few years. The tribe Chrysobalanoidex is confined to the tropics and the Neuradoidex to the subtropics of Africa and southwestern Asia. All of the other tribes of Rosacex are wirlely distributed and their modern and fossil distribution is withont especial significance for the present discussion.

The only genus represented in the Wilcox is Chrysobalanus with two species that are evidently the prototypes of the still existing forms. The latter are but two or three in number and as shrubs or small trees they inhalit the sandy shores in the maritime regions of Florida, tropical America and western tropical Africa.

The Leguminosie as now segregated into + families constitutes 
the largest alliance among the Choripetale (Archichlamydea), and next to the Composite the largest angiospermous group, with orer 9,000 existing species segregated among about 450 genera.

There is a well-defined floral progression from the family Mimosacere with its actinomorphic flower's and numerous, usually free, statmens, through the Ciesalpiniaceat, culminating in the numerically greatcis group the l'apilionacee with its strongly zygomorphic fluwers and coalesent stamens, comparable with the like culmination in floral erolution of the ()rchidacea among the Monocotyledonat.

The $M$ inusacer, with alout 30 genera and r.foo exi-ting species. are massed in the tropics of both hemispheres. None of the subfamilies are confined to a single continent but comparatively few genera occur in more than two continental areas and half the genera are restricted to a single continent. Asia and Australia each have two peculiar genera, Africa has four and America has seven. America also leads in number of species, about half the total of the family being present in the New Morld. Australia comes next with over 300 , Africa next with upwards of 300 and Asia last with about I00. In the eastern United States there are only three genera and five species, none of which are arborescent. In the Gulf States the numbers have increased to 14 genera and 44 species.

The Citsalpiniacere with about 90 genera and $\mathrm{r} .000$ species is also mainly tropical with a massing of forms in the American tropics where there are over 600 species and 37 peculiar genera, the subfamily. Sclerololbie being entirely. Imerican and containing numerous monotypic genera. Asia and Africa each have about I5o species. There are, however, only Io Asiatic genera as compared with I7 African. There are but three Australian genera and less than Ioo species. In the eastern United States there are 5 genera and eleven species. Three of the genera, Cercis, Gleditsia and Gymnocladus are arborescent. In the southern states there are II genera and 44 species.

The Papilionacere have about 320 genera and 6,600 species. America learls in the number of peculiar genera having $s_{2}$ while Asia leads in the number of species with about 1,700 . Africa has

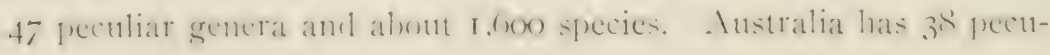


liar genera and about $\mathrm{I}, 000$ species. Asia has 33 peculiar genera, while Europe with 7 peculiar genera and about 700 species is less rich in both species and genera than any other continent. None of the subfamilies are confined to a single contintent but some of the tribes are, the Lipariinæe being South African and the Bossixinæ being Australian, while 20 of the 27 genera and all but 63 of the $43^{6}$ species of the subfamily Podolyrieæ are Australian. Two genera in this subfamily are American, 2 African, I Asiatic, I Mediterranean (Eurasia) and I common to North America and Asia.

In the eastern United States there are 46 genera and 194 species of Papilionacex, the genera Cladrastis and Robinia being arborescent. In the southern states there are 55 genera and $3 \mathrm{I} 8$ species. Sargent's "Manual of North American Trees," which includes many tropical forms of the Florida Keys, enumerates for the Leguminosæ as a whole only 34 arborescent species for North America in I7 genera.

In Grisebach's flora of the British West Indies the Leguminosæ outnumber all other families of flowering plants with 262 species. The same is true of Urban's flora of Porto Rico where they number 136 species.

The Leguminose found in the Wilcox deposits number over fifty species, many of which are individually abundant. They represent the families Mimosacer, Cresalpiniacere and Papilionacer, the fourth family of the leguminous alliance, the Krameriacee, being a small herbaceous group of the New World of very late, probably of recent, evolution.

Of these fifty-odd Wilcox species eleven are referred to the Nimosaceæ, 26 to the Cæsalpiniaceæ and 20 to the Papilionaceæ. Definitely recognized genera are named in the usual way. Forms usually identified as species of Acacia (as for example most of those so named by Ileer, Ettingshansen, (nnger, etc.) which are referable to the Mimosacere but not to the genus Acacia as commonly understood are referred to the form-genus Mimosites. Forms not certainly identified as Casalpinia but referable to the Casalpiniacea are classed under the form-genus Cosalpinites while a considerable numwer of (ilcditsia-like forms of both leaves and pods are described in 
the genus Gleditsioph1/lum, a form-genus proposed by me in the first instance for an Upper Cretaceous form from North Carolina. There is a certain mavoidable duplication in the giving of specific names to unattached pods and leaflets since in some cases they may belong to the same botanical species. I have followed this methorl. however, in all instances where I was not sure of such a relationship.

The Mimosacex of the Wilcox are referred to four genera. The genus Acacia represented by a single indisputable species in which the leares are reduced to phyllodes is of great interest since in the existing flora the $45^{\circ}$ species are largely confined to the Australian region. The section Phyllodinex to which the Vilcox species is referred has about 300 existing species which are confined to . Instralia and Oceanica although in Eocene times they were also present in Europe. It is a curious commentary on the modern character of the earlier Tertiary floras that the reduction of foliar organs and the halbit of phyllody, often correlated with modern arid conditions. should have really been developed in these early floras.

The genus Inga, represented in the Vilcox by four well marked species, has upwards of 150 species in the existing flora, all of which are confined to the American tropical and subtropical regions. Its geological history is for the most part unknown although it appears to be represented in American Lpper Cretaceous floras by Incla critacea Lesquereux which occurs in the Dakota Sandstone and in the Tuscaloosa formation of Alabama. Ettingshausen has described a species from the Cenomanian of Saxony (Inga Cottai) and the Furopean Viocene has furnished two or three species. While Engelhardt has described a Tertiary species from Bolivia.

In the genus Pithecolobium, which has two Wilcox species and belongs to the same tribe as Inya ( Ingea), while the majority of the IOO or more existing species are American there are over a score in tropical Asia and a few in tropical Australia and Africa. With the exception of a Tertiary species from Bolivia I do not know of other fossil occurrences.

The genus Mimosites, with four Wilcox species, represents trees of the Jimosa type very abundant in recent species referred a sereral senera which are cither American. Asian, Anstralian or . Irican, 
and abundantly represented in European Tertiary floras. Its Cretaceous ancestry is hidden among the species of leaflets referred to the form-genus Leguminosites. The genus Mimosa which is apparently most like the Wilcox Mimosites, has over 300 existing species and these are for the most part confined to the warmer parts of America, although they are represented in Asia, Africa and Australia.

Except for the family Lauraceæ the Cæsalpiniaceæ with 2.6 species is the largest family in the IVilcox flora and it is certainly a fact of considerable interest that the massing of the modern species in the American tropics should be foreshadowed by their numerical abundance on this continent as early as the Lower Eocene.

The IVilcox genera are five in number of which the largest is Cassia with twelve species. Cassia is the largest Wilcox genus except Ficus, and all of its species find their modern counterparts in existing species of tropical and subtropical America, many of which are mentioned by name in the systematic part of this work. Numerous as are the Wilcox species of Cassia there was apparently greater specific differentiation in contemporaneous European deposits since Ettingshausen records I5 species in the flora of Alum Bay (Ypresian of Isle of Wight). Cassia has between three and four hundred existing species found in the warmer temperate and tropical regions of all the continents and especially abundant in tropical America. Their place of origin is unknown since they make their appearance in the Upper Cretaceous almost simultaneously in New Zealand, Australia, Bohemia, Saxony, Greenland, the Atlantic Coastal Plain and the Dakota Group of the Rocky Mountain province. Upwards of one hundred fossil species are already known. Nor does the Eocene distribution shed any light on the early history of the genus since species occur in such widely separated regions as North America, Europe and Australia. There are numerous Oligocene and Miocene species, the Oligocene records being confined to Europe and Africa and the Miocene records being confined to Europe and North America. Cassia was abundant along the shores of the Pliocene Mediterranean of Europe and 4 species are recorded from South American heds which are thought to be of Pliocene age. Pleistocene species

PROC. AMER. PHIL. SOC., LIII,, 2 I 4, L, PRINTED JULY II, I9I4. 
are recorded from Maryland and the East Indies (Java) associated in the latter region with Pithecanthropus erectus Dubois. One fact is certain, the genus has been a part of the American flora since the dawn of the Lpper Cretaceous, and several of the II ilcox species are the undoubted prototypes of existing forms of the American tropics.

The genus Corcis, with a single Wilcox species, makes its first recorded appearance in geological history in the Milcox species, in the three species recorded from the Ft. Lnion deposits of the Rocky Mountain province and a fourth species found in the Ypresian of the Paris basin, so that its appearance was practically contemporaneous in France and Tennessee. It continues on both continents down to the present being even represented in the Pleistocene of both. The modern species number five or six and inhabit the warmer temperate regions of America, Europe and Asia.

There is one species of Casalpinia in the Wilcox and it is almost illentical in character and habitat with Cosalpinia bahamonsis Lamarck of tropical America. The existing species number about two score of the tropics of both hemispheres. Cicsalpinia is recorded first from the Lpper Cretaceous of the Atlantic Coastal Plain and it seems probable that it originated on this continent and reached Europe during the Eocene by way of the Arctic region, since it is common in the Oligocene, Miocene and Pliocene of the latter continent.

Four Wilcox species are referred to the form-genus Casalpinites. The:e represent true forms of Cosalpinia or of allied genera in this family, one almost certainly representing the genus Parkinsonia, a small genus which occurs in the European Oligocene but which in the existing flora is confined to the warmer parts of North America and South Africa. Fossil forms referred to Casalpinites include alont twenty of the European Oligocene and Viocene.

The genus Gleditsiophyllum makes its appearance in the Lpper Cretaccous of the Carolina region. It is represented by eight specics of leaves, leaflets and pods, often abundantly preserved, in the II ilcox deposits. Their relation to molem genera is uncertain, although they were evidently much like Gleditsia. 
Two genera of Cæsalpiniaceæ which I confidently expected to find in the Wilcox and which must have been present during this time in southeastern North America are Hymencea and Bantinia. The former is confined to the American tropics in the existing flora where it has about eight species. It is represented by characteristic forms in the Upper Cretaceous of Alabama. The genus Bautinia which has about 50 existing species of the tropics of both hemispheres has several especially characteristic forms in the Upper Cretaceous of southeastern North America (New Jersey, Maryland, Alabama).

The family Papilionaceæ which comprises over two thirds of the existing Leguminosæ undoubtedly represents the culmination of evolution in the alliance. The bulk of the family, especially the numerous herbaceous genera, are unquestionably of comparatively recent origin. In spite of this fact the family has twenty species in the Wilcox. These are distributed among six genera, of which Dalbergitcs, Carpolithus and Leguminosites are form-genera, while the other three are still existing. The largest genus is Sophora with seven species, one of which, evidently a strand type similar to and comparable in habitat with the cosmopolitan strand plant Sophora tomentosa Linné of the existing tropical flora, is very abundant in the Wilcox deposits. There are about 25 existing species of shrubs and small trees referred to this genus. They are scattered over the warmer parts of both hemispheres and are found on all tropical seashores. About a dozen fossil species are known. In addition to North America they are found in both Europe and Asia during the Eocene, a single form from Alum Bay (Ypresian) being contemporancous with the Wilcox species and the others being later. While few species have been described the genus is widely distributed in the European Miocene where Sophora europaca Unger was a common coastal form of the Mediterranean region throughout the Miocene and into the Pliocene.

Four species, three based on leaflets and the fourth on a characteristic pod, represent the genus Dalbergia in the Wilcox flora. Two additional species whose generic relations are not so certain are referred to the genus Dalbergites. The existing species of Dalbergia 
number about eighty forms found in the tropics of both hemispleres. and all show a strong generic similarity in their foliar characters. Over two-score fossil forms are known. The earliest of these occur in the Itlantic Coastal Plain and western Greenland so that there is a strong possibility that the genus was of American origin. If this theory was correct they must have undergone a rapid radiation since in the Eocene they are not only found in America and the Arctic but in Europe and Australia. The Alum Bay beds of the lsle of Wight ( Ypresian) which I regard as contemporaneous, in part at least, with the Wilcox, contain according to Ettingshausen, six species of Talbergia. European deposits furnish about a dozen ()ligocene species and still more numerous Miocene species. Dalbergiu primer'd Lnger, D. retuscfolia Heer, D. haringiana Ettingshausen and $D$. bella Ifeer are willespread coastal forms of the European Tertiary, some of them ranging from the late Oligocene through the Miocene and into the Pliocene.

The genus Canaralia is represented in the Wilcox by a fine species undoubtedly ancestral to the existing Canazalia obtusifolia (Lamarck) De Candolle, a widely distributed tropical strand plant. $A$ second species is less commonly represented and not as certainly irlentified. The genus contains about a dozen existing species of the tropics of both hemispheres but has not been heretofore found in the fossil state.

The Wilcox forms referred to Leguminosites cannot be dealt with satisfactorily since they represent pods and leaflets of this alliance whose generic relations are uncertain. The form-genus was proposed first by Towerbank for the pyritized remains from the Island of Sheppey (I ondon Clay), and two of his species are tentatively identified in the Wilcox. Subsequently many species have heen described. They range in age from the Middle Cretacenus to the I'liocene. Saporta decribes the oldest form in the Vlbian of Portugal. They are present in the Cretaceous of Australia, the Comomanian of Saxony, the - Itane and Patoot beds of Circenland. and the Atlantic Coastal I'lain Cretacens from Marthas Vineyard to Alabama. They are common in the Arctic Eocene, occurring alse in Mustralia. America, Europe and Asia. Oligocene records in- 
clude Europe and Antarctica, Miocene records are confined to America and Europe and Pliocene records include southern Europe and Japan.

While the foregoing analysis leaves a great many points in the history of the Leguminosa unsolved it serves at least to show that the Wilcox forms are all represented and would find a congenial habitat in the present day American tropics and that thus early some of the main features of their present day development had been differentiated.

The most similar fossil display of these forms is to be found in the Ypresian flora of Alum Bay on the Isle of Wight, which unfortunately have never been described or figured, but of which Ettingshausen ${ }^{28}$ published an analysis and enumeration in I880. Another very similar display of forms is that described by Engelhardt from the Tertiary of Cerro de Potosi in Bolivia. ${ }^{29}$ The exact age of the latter has never been determined although its resemblance to this part of the Wilcox flora suggests the possibility that it is Eocene instead of Pliocene, which later has been assumed to be its age. This may, however, simply be a reflection of the similarity between the Leguminosæ of the Embayment area in the Lower Eocene and those of subsequent periods in the American tropics.

The order Geraniales includes 2I families, with upwards of ten thousand existing species, of which nearly one half belong to the family Euphorbiacex. The other large families in the order of their size are the Rutacex, Meliacex, Malpighiacex, and Polygalacer each with over five hundred existing species, while the Geraniacce, Oxalidacex, and Burseracex each have over three hundred existing species. The alliance is mainly cyclic in the character of its floral members, starting with isocarpic forms and progressing in the direction of reduction in the number of carpels. The phylogenetic importance of the characters by which the Geraniales as an order is separated from the evidently allied Sapindales is not great and in some respects the order is apparently not a natural one. Six families of Geraniales have been recognized in the Wilcox flora. The

${ }^{28}$ Ettingshausen, Proc. Roy. Soc. Lond., Vol. 30, 1880, pp. 228-236.

${ }^{29}$ Engelhardt, Sitz. naturwiss. Gescll. Isis in Dresden, 1887, Abh. 5, pp. 36-38, 7 Figs.; Ibid., I894, Abh. I, pp. 3-13, Pl. I. 
first of these, the Rutacex, consists of about III genera and over goo existing species willely distributed over the warm temperate and tropical regions of the earth. The fruits are capsules, samaras or drupes and the leaves which may be simple or compound are usually glandular punctate. While there are $3+$ genera with 127 species contined w America the family makes its greatest display in the Old Miorle, Africa having i6 peculiar genera with 196 species and Australia 28 peculiar genera with 185 species. In addition to 6 genera with 7 species confined to the Asiatic Mainland there are In genera with 16, species found distributed from southeastern . Isia through Malaysia greater or less distances, in some cases to New Zealand and l'olynesia. The only truly cosmopolitan genus is Fagara with upwards of $I_{50}$ existing species and represented in all tropical countries. The tribe Boronieæ with I8 genera and 158 species is confined to Australia and New Zealand; the Diosinere with I I genera and ISI species is confined to South Africa; and the Cuspariea with If genera and $8_{3}$ species is confined to tropical America. All of the other rather numerous tribes are represented in more than one continental region.

The family contains the remarkable number of 42 monotypic genera and while many of these may be regarded as of recent erolution, as for example a number of those of Australia, the isolated occurrences of many of the others indicates that they are of great age and once occupied intervening areas.

There are only twelve known fossil genera, or only about io per cent. of the existing genera, so that little can be said of the fossil history of the family. The oldest genus is Citrophyllum Berry represented by very characteristic leaves with alate petioles found in the Dakota sandstone of the Rocky Mountain province and from New Jersey to Alabama along the Atlantic coast in the Raritan, Magothy, Midilendorf and Tuscaloosa formations. There is a second species of Citrophyllum in the Irikox and a third in the orerlying Claiborne. These forms are very similar to the leaves of recent members of the Aurantioilea and undoubtedly represent ancestral fornts. The genus l)ictammus Linne with a single existing species wirlely distributed in Furasia, has furnished a fossil form in the l'incene of France and a second in the Pleistocene of Japan. Unge 
in I850 described petrified wood from the Aquitanian of Greece as Klippsteinia medullaris referring it to the Aurantioidex.

The genus Amyris (P. Browne) Linné has about a dozen existing species in the Antilles and Central America, two of which reach the coast of southern Florida. A fossil form is recorded by Unger from the late Miocene (Sarmatian) of Hungary. This determination is not conclusive however although Unger had both the leaves and fruit of Protamyris berenices. Unger also described the supposed ancestral genus Protamyris to which he referred four species from the Aquitanian of Kumi and the Miocene of Croatia. These are not especially convincing and both Ettingshausen and Schenk consider Protamyris radobojana Unger to represent a species of Cedrela.

The genus Xanthoxylum Linné with nine or ten existing species of eastern Asia and North America has been a favorite receptacle for fossil forms of Rutacere. About a score of species have been described, the oldest coming from the basal Eocene of New Mexico (Raton formation) while a second Eocene species is recorded from the Bartonian of France. Engelhardt has described two Eocene or Oligocene species from Chili. There are four Oligocene species, two in France and two in Prussia. There are about thirteen Miocene species, widely distributed and represented in California, Colorado, Spain, France, Switzerland, Baden, Bohemia, Croatia and Hungary: The two Pliocene species represent France and Asia Minor and one of the recent species is found in the Pleistocene of Japan. It seems probable that Xanthorylum was derived from Fagara through a loss of the floral calyx and by adaptation to less tropical climatic conditions.

The genus Fagara Linné is substituted for Xanthoxylum by many recent systematists, although $I$ prefer to consider it as the ancestral stock and in the older sense as including the 150 cosmopolitan tropical species while Xanthorylum includes the extratropical forms of Asia and North America. Undoubtedly several if not all of the fossil forms described as species of Xanthorylum are more properly referred to Fagara although none have heretofore been described uncler this name. The Tertiary flora of southeastern North America contains several very characteristic forms of this genus. The oldest 
are three species from the Wilcox Group. There is another in the overying Claibone Group. The Ticksburg Group has furnished a very common form with several well-marked varieties some of the leaves of which show their glandular punctate character beautifully preserved. Still another form is found in the Apalachicola Gromp of Florida.

The genus Ruta Linné with upwards of Ioo existing species mostly of Eurasia although present in Africa and South . America, has furnished Menzel (I9I3) with characteristic capsules in the Aquitanian of Rhenish Prussia.

The genus Phellodendron Rupr. with two existing Asiatic species is represented in the Aquitanian of Rhenish Prussia hy iruits (drupe). Iingelhardt has described species of Ticorea, Pilocurpus and Erythrochyton from the early Tertiary of Chili.

The remaining genus with fossil representation is Ptelea Linne which has 7 or 8 existing species ${ }^{30}$ confined to the Linited States and Mexico. The fossil forms are represented by both leaves and characteristic fruits. The oldest comes from the Arctic Eocene. There is a species in the ()ligocene of Italy and six Miocene species, occuring in Colorado, France, Switzerland, Carniola and Hungary. A Pliocene species is recorded from Italy. Obrionsly the record will have to become much less fragmentary before any creditable conclusions can be trawn respecting the place of origin and geotngic history of the Rutacex.

The family Simarubacer (often spelled Simaroubaceæ) includes about 28 genera and upwards of I $_{5}$ o existing species of shrubs or trees with pinnate leaves and drupaceous fruits, confined chiefly to the tropics and the warmer parts of the northern hemisphere. Only three of the existing species reach as far northwarl as the coast of sutulem lorida. The family is still rupresented on all the continents except Europe. Two genera with four species are confined to Asia; 3 genera with 4 species are confined to Australia; 4 genera with 6 species are confined to Africa and 9 genera with $7 \mathrm{I}$ species are confined to America. The most widespread species is the monotypic Surama maritima I.inne a cosmopolitan tropical strand plant occurring wn the dunes. keys and coastal hammocks of southern Florida.

${ }^{30}$ Greene has recently described very many poorly established new species. 
The only genus represented in the Wilcox is Simaruba Aublet, which has furnished a single species, Simamba eocenica Berry, closely resembling the existing Simaruba glauca De Candolle which is found along tropical coasts from southern Florida to Brazil.

The only other genus with a geological history is Ailanthus Desf. which has 7 existing species of eastern Asia and the East Indies. ${ }^{31}$ The fossil species number about fifteen. There are two in the Eocene of IVyoming and Oregon; eight in the Oligocene of France, Alsace, Styria and Prussia; and five in the Miocene of France, Switzerland, Baden, Italy and Colorado. While in the absence of collateral evidence that the Eocene occurrences in North America have any significance regarding the origin of the genus it is an interesting speculation that the genus originated in North America and subsequently reached Asia by way of the Eocene land connection across Behring straits. Certainly the genus lingered on this continent, as is evidenced by its presence at Florissant, as late as the Middle Miocene.

The family Meliaceæ contains about 42 genera and about 680 existing species of shrubs and trees with pinnate leaves. The vast majority are found within 30 degrees of the equator although they reach $40^{\circ}$ north in eastern Asia and $40^{\circ}$ south in New Zealand. Moreover the China berry (Melia azedarach) has been cultivated from time immemorial in all Mediterranean countries, and throughout the southeastern United States since its settlement, and is perfectly hardy. There are no temperate outliers however. While the Meliacere occupy a greater continuous area in South America where over 4I per cent. of the existing species occur, this large number of species (about 285 ) represent only i9 per cent. of the known genera. There are some remarkable similarities between the species of the American tropics and those of West Africa. Thus the two small genera Swietenia and Carapa are represented in both areas and Carapa procera is even said to be common to the two. Moreover the genus Guarca which has ahout So species in the American tropics has three in West Africa. The larger number of genera are found in the S. E. Asiatic region and the number of genera and their mutual

31 Alianthophyllum Dawson with a single species is described from the Eocene (?) of British Columbia. 
affinities decrease from - Isia wward - Ifrica and also through Polynesia. A number of genera (Toona, Xylocarpus, Cipadessa, Melia) extend from Africa through Asia to Malaysia. Two genera are peculiar to Australia i Symum. (O) enila) and two to Polynesia (I aace. Moldidfoll. There are thirteen monotypic genera of which six are African and seven Asiatic. From the distribution of the existing species De Canchlle" infers that southern - Isia is the center of radiation of the family. I am inclined to think however that the reverse is probably true since the oldest known forms, except the entirely loubtful celrelospermites of Saporta from the Valanginian of I'ortugal, are Imerican, and the wilespread existing American representation of the family seems to comprise the specifica!ly multiplied descendents of the original stock alrealy represented in the Wilcox flora.

The Asiatic genera would represent immigrants into that area or forms evolved there. The Polynesian and Australian forms are much localized derivatives of the Indian stock and unless the pectliar species of few Caledonia conld not reach that region except by a land connection it may be inferred that this Asiatic radiation was relatively recent.

The fossil species are unfortunately few in number. So far as I hnow the only fossil species of Carapa is that found in the IVilcox. Its occurrence in the early. Eocene is at least a factor in explaining its present distribution in both the American and West African tropics. The fact that Carapa procera is common to these two areas may suggest that all of the African species are recent immigrants, but it is more probable that there are unrecognized specific differences in this form in the two areas and that the present disconnected distribution is an example of survivors from the early Tertiary radiation. Another genus with a modern distribution like Carapa is the genus Moschorylon Jusieu (made a section of Trichilia Linné by Harms in Engler and I'rantl) which has about fo species of tropical Anerica and West Africa. This has furnished two fossil species described by Engelharlt from the early Tertiary (Eocene or Oligi)(ene) of Chili. The genus Cedrela, sometimes made the type of an

32 De Candolle, C. de, "On the Geographical Distribution of the Meliaccre," Trans. Limn. Soc. Lond., 2 ser., Bot., Vol. I, 1880, pp. 233-236, Pl. 30, 3 I. 
independent family, the Cedrelacer, has four IVilcox species, Eocene prototypes of existing American species. This genus with 9 or IO species is confined to America in the existing flora and is only known outside this area in two species from the Miocene of Croatia which Unger referred to Cedrela and an undescribed Cedirla recorded by Ettingshausen from the Ipresian of the south of England. Saporta has, howerer, recorded six species of Cedrclospermum from the Sannoisian of southeastern France. The fossil record of these three genera Carapa, Moschom $\%$ ond Codrcla, brief as it is, show's clearly that the Meliacex are not a modern element in the flora of the American tropics but one that was already well differentiated in the early Tertiary.

The remaining fossil references to this family comprise Meliaceccarpum based on capsules from the Aquitanian of Prussia which Menzel their describer compares with those of the genera. Dy'soxylum and Guarea. F. von Nüller has described Rhytidotheca and Pleioclinus, two supposed meliaceous genera based on fruits, from the Pliocene of Australia.

The family Humiriacex is a small one, comprising only three genera and a score of species of shrubs and small trees all of which are confined to the American tropics except a single species found in tropical Viest Africa, a distribution suggesting a history comparable with that just suggested for Carapa, Moschorylon and Cedrela. The only known fossil species is one from the Wilcox very close to the existing I'antanea paniculata Urban of northern South America.

The family Malpighiaceæ, confined to tropical and subtropical countries, contains about 55 genera and 650 existing species, many of which are scandent, including some of the finest lianas of the tropics with stems $2 \mathrm{dcm}$. in diameter. Others are shrubs and trees. The leaves are opposite and simple and the fruits drupaceous, capsular, or nutlike, and often winged. The only species that reaches the Uniter States is Byrsonima lucida (Swartz) De Candolle, a small evergreen tree of the Florida keys.

The family is predominantly American in its distribution, over 67 per cent. of both genera and species being confined to the Mestcrn Hemisphere ( 37 genera and 40 species). The genera are all lical in the sense that none occur in more than one continental area. 
Of the two sub families into which the family is divided-the I'yramidotore and Planirote, the latter with two tribes Galphimiece and Malphighice are entirely. American. ()i the three tribes into which the Pyamidotora is divided the Tricomatrea are entirely . Imerican, the Ilirese have 3 genera and 23 species confinerl to . Lia, 3 genera and I 2 species confined to $\triangle$ frica, a genus with I 2 species ranging from Malayasia to - Instralia, and 9 genera with is I species confined to America. The remaining tribe, the Banisterice, has a monotypic gentus in Asia, 2 genera and $y_{5}$ species in Africa, a single gentus with 7 species ranging from the East Indies to Australia and I genera with 247 species confined to America.

There are 2I monotypic genera distributed as follows: Microsteira confined to Marlagascar: Filabellaria confined to Africa: Cuucanthus confined to Arabia: Brachylophon confined to farther India : Mewia, Diplopteris, Lophopteris, Clonodia, Colcostachys, Blepharandra, Lophanthera, Verrucalaria, Pterandra, Acmanthera, Diacidia, anci Glandonia confined to IBrazil, Guiana and Venezuela: Itonlioflytum confined to Cuba: Lusiocartus and Eclimopteris confined to Mexico: and Tricomaria and Mionandra confined to Argentina.

Monotypic genera in general are susceptible of two interpretations, i. e., they represent either the last survivors of a long line as in the case of the Ginkgo, Sassafras, etc., or they represent relatively' recent specializations. In the case of the foregoing monotypic senera it seems probal)le that the majority are the result of relatively recent corlution since there is nothing in their character or distribution to sngesest any extended genlogic history and none have been found in fossil floras.

The fossil record is most incomplete. No forms are known from the Lpper Cretaceous for although Ettingshatisen recorled a species of . Malphighastrum and one of Banisterioplyllum from the ipper Cretaceons of Anstralia, those illentifications are open to the most scrious question and I do not consider them of any weight in a discussion of this kind. The family is certainly represented in the lower Focene hy five species of Malpighiastrum. Hirca and homisteria in the Ypresian of the south of England and by five species of Ilired and banisteria in the Wilcox flora, hased upon both leaves and

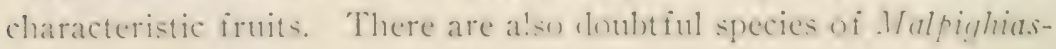


trum and Banisteriophyllum described from the Eocene of Australia by Ettingshausen. Thus there is no direct geologic evidence of the place of origin of the family. The fact that it is so predominantly American at the present time and that only two genera have reached Australia from the East Indian region and that two of the American genera appear in the northward extension of the early Eocene flora of the American tropics during the Wilcox and are as ancient as any certain records of the family anywhere, renders the conclusion that the family originated in equatorial America an extremely probable one. With the exception of the Wilcox records enumerated above nearly all of the fossil records relate to Europe, and these may be briefly enumerated.

The genus Malpighiastrum of Unger has about 30 recorded species. These include the doubtful Lpper Cretaceous and Eocene species previously mentioned as recorded by Ettingshausen from eastern Australia; 3 Ypresian species from the south of England; eight Oligocene species in France, Italy, Dalmatia, Styria and Transylvania; about 15 Miocene species in Italy, Prussia, Bohemia, Croatia and Transylvania; and two Pliocene species in Italy.

The genus Heteropteris Jussieu, with about 90 existing species ranging from Mexico and the Antilles to Bolivia and Brazil, has a late Oligocene species in Transylvania and two Miocene species in Styria and Croatia.

The genus Hirca Jacq., with about 25 existing species ranging from Mexico and the Antilles to Peru, has furnished about ten fossil species, based for the most part on the winged fruits. There is a species in the Ypresian of southern England and a characteristic fruit in the Wilcox; four Oligocene species in the Tyrol, Styria and Transylvania; three Miocene species in Baden, Styria and Transyvania; and a Pliocene species in Brazil.

The genus Tetrapteris Cav., with about 60 existing species ranging from the West Indies and Mexico to southern Brazil and Bolivia, has furnisher a fossil species in the Oligocene of Styria and three Miocene species in Bohemia, Styria and Croatia.

The genus Stigmatophyllon Jussieu, with about 45 existing species found in the Pahamas and Antilles and along the east coast of America from Mexico to Uruguay, has furnished Saporta with a 
somewhat doubtful form from the Upper Oligocene of France. Similarly the genus Byrsonima L. C. Rich., with go existing species ranging from the Bahamas and Mexico to southern Brazil and Inlivia has been recorded by Massalongo from the early Pliocene of Italy, but the identification is extremely doubtful.

The genus Banisteria Linné contains about 70 existing species of climbing of scrambling shrubs ranging from the West Indies throughout tropical South America. It is represented by four species based upon both leaves and fruits in the Wilcox; there is a Jpresian species in the south of England; four Oligncene sjecies in France, the Tyrol, Alsace and Styria; and four Miocene species in France, Switzerland and Croatia.

The genus Banisteriophyllum Ettingshausen with a single [pper Cretaceous and an Eocene species in eastern Australia I regard as of rery doulut ful affinities. Schenk also states that wond of a malpighiacenus type occurs among the silicified woods from the Oligncene of the Island of Antigua.

The family Euphorbiaceæ is sometimes made the type of a distinct order, the Euphorbiales, although the significance of the characters by which it is segregated from the Geraniales is not obvious. It is an exceedingly large alliance with about 220 genera and 4.000 existing species (I'ax, I890) of herbs, shrubs and trees, widely distributed throughout the tropical and temperate zones. The genus Euphorbia with over 700 species is perhaps the most wirlely distrihnterl genus in the fanily. A very large number of the recent specics, particularly those of xerophytic character so closely simulating the Cactacer, are of relatively recent evolution.

In such a multiplicity of existing genera and species any effort to trace the larger features of distribution would oceupy more space than it is worth in the present connection. Four arborescent genera with five species reach the Lnited States in the Floricla region, and several alditional are naturalized in that area. I considerable. but relatively insignificant, number are recorded during the Lpper (retaceous and Tertiary. The fossil records will, however, have to be greatly increased heiore they can he said to shed any definite light on the geological history of the family. Enough is now known, 
however, to abrogate the statement made by Schenk $\mathrm{r}^{33}$ and quoted by $\operatorname{Pax}^{34}$ that there is no certain evidence of the existence of the Euphorbiacex during the Tertiary. The following genera have been recorded as represented in the fossil state.

Euphorbia with a single species based upon a fruit described by Heer from the Swiss Miocene: Euphorbioides based on an inforescence described by Wessel and Weber from the Aquitanian of Rhenish Prussia; the genus Euphorbiophylium with several species to be noted presently; I have described a very characteristic species of Manihotites from the Upper Cretaceous of Georgia; the genus Crotonophyllum has several Upper Cretaceous and Eocene species; Cluytia is reported from the Eocene of the Isle of Wight and the Oligocene of Saxony and Rhenish Prussia; the following genera each with a single species were identified by Ettingshausen from the Miocene of Bohemia, i. c., Adenopcltis, Baloghia, Omalanthus and Phyllanthus. Conwenz has described a euphorbiaceous flower from the Baltic Amber (Sannoisian) as Antidesma maximowiczii and Felix has described petrified wood from the Tertiary of the U. S. of Columbia as Euphorbiorylon. Hura-like fruits are also recorded by Knowlton from the lower Eocene (Raton formation) of New Mexico. Engelhardt has recorded species of Omphalca Linné, Tctraplandra Baillon and Mallotus Lour., from the early Tertiary of Chili.

While difference of opinion regarding the determination of some of these records is justifiable I regard I Inihotites, Euphorbiophyllum, Crotonophyllum and Euphorbiorylon as definite evidence of the existence of the Euphorbiacere during the Upper Cretaceous and Tertiary.

The Wilcox species are five in number and are referred to the genera Crotonophyllum, Euphorbiophyllum and Drypetes. The genus Crotonophyllum was proposed by Velenovsky for a wellmarked species from the Cenomanian of Bohemia. I have described a second species from the Upper Cretaceous of South Carolina. Two species are recognized in the Wilcox and of these Crotonophyllum

${ }^{33}$ Schenk, "Palæophytologie," pp. 594-597, r89o.

${ }^{34} \mathrm{Pax}$, in Engler and Prantl's "Naturlichen Pflanzenfamilien," I89o. 
contiom Perry may be successfully compared with a number of the six hundred existing species of Croton which is so abundantly represented in tropical America. Comparisons are especially close with (roten cluteria (Linné) Bennett which is found in the low cop)pice of the beach ridges throughout the Bahama islands.

The genus Euphorbiophyllum was proposed by Ettingshausen in I853 for several species from the Sannoisian of the Tyrol. Altogether over a dozen species have been described by Ettingshausen, Saporta and Engelhardt. These have been compared with the existing, mostly tropical American, species of Styloceras, Sapium, Stillinuir, Adenopeltis, Erociaria, Colliquaja, etc. The oldest comes from the Cenomanian of Portugal and a second Lpper Cretaceous species occurs in the Turonian of southern France. In the Eocene there is a species in West Greenland, a second on the Island of sheppey (Ypresian) and a third in the Paris basin (Lutetian). Five Oligocene species have been described from the Sannoisian of the Tyrol, and a sixth from the Chattian of northern Bohemia. There are two Mivene species in Switzerland and two in Styria: a Pliocene species is described by Krasser from Brazil. A single small-leafed species of Euphorbiofhylum is of rare occurrence in the midclle Wilcox.

The genus Drypetes Vahl. has about a dozen existing species confined to tropical and subtropical America. Three extend southward to northern lirazil and two range northward to the filorida keys. There are two well-marked species in the Wilcox flora-one an Eocene prototype of the existing Drypetes keyensis Urban, and the cother of the existing Drypetes lateriflora (Swartz) Urban, both small trees of the coastal flora of southern peninsular Florida, the Bahamas. Tlest Indies and Antilles. The genus, which has not previously been recorter in the fossil state, was probably of American origin and there is no evidence that it ever spread to the eastern hemisphere.

The order Sapindales, sometimes called the Celastrales, includes srme twenty families, together containing about 3.200 species, the largest families in the order of their size being the Sapindacex which has more than twice as many species as any of the others: the Celastracee, Anacardiaceat, lialsaminacer, and Ilicacea. As in the preceding order, the Sapindales start with isocarpic forms and pass to 
those in which the carpels are reduced in number, and in the more evolved families the flowers have become zygomorphic. Since there are several distinct lines of development and the separation from the Geraniales is based on characters that seem trivial, it seems probable that the families comprising these two orders as at present understood represent a plexus of forms whose filiations are nat yet understood.

The first family of the Sapindales that is represented in the Wilcox flora is the Anacardiacex, an exceedingly natural group. It contains about 58 existing genera and 435 species of shrubs and trees with round pithy branches, resinous and frequently toxic juice, alternate, simple, palmate or pinnate, exstipulate leaves, and drupaceous fruits with exalbuminous seeds. The Anacardiacer makes its greatest display in the tropics and subtropics of both hemispheres but in the existing flora is especially characteristic of the Malaysian region. Rhus is by far the largest gents and the only one of the family found in the extra tropical regions of both the northern and southern hemispheres. The present geographical distribution shows many anomalies throughout the family. Thus the genus Camposperma Thwaites has eight species in Madagascar, Ceylon, Sumatra, Borneo and the Malaccas and a single species in northern Brazil. The genus Sorindeia Thouars of tropical Africa and Madagascar is most closely allied to the genus Mauria Kunth of the Andes of South America. The genus Calesium Adanson has 13 species in tropical Africa and one in the East Indies. The Eurasian genus Pistacia Linné has a single species in Mexico. The genus Thyrsodium Bentham has 4 species in the Amazon region of South America and one in tropical West Africa. The subfamily Mangiferæe with about 80 species is entirely Malaysian except for a species of Gluta Linné in Madagascar and the genus Anacardium Linné which is confined to tropical South America, chiefly in Brazil. The subfamily Spondiex is found in the tropics of all the continents, excepting Europe. The subfamily. Rhoidere is found on all the continents and shows a pairing of a consiclerable number of genera in equatorial Ifrica and America. The two remaining subfamilies, the Semecarpex and the Dobineex are restricted to the region extending from India to Australia. The PROC. AMER. PHIL. SOC, LIII, 214 , M, PRINTED JLLY I3, I9I4. 
family contains twenty monotypic genera distributed as follows: Asia 5. Australia 3. Africa 6, Madagascar 3, North America 2, and South America I.

The fossil records of the Anacardiacex are very incomplete although there seems to be no dould that it was represented in both Europe and North America as far back as the Upper Cretaceous. As in the existing flora the most abundant genus in the fossil record is Rhus to which over one hundred species have been referred. Eight of these are Upper Cretaceous forms the oldest coming from North Anerican strata correlated with the (enomanian (Raritan, Dakota). The genus appears in Europe in the Turonian of Pohemia. There are over a dozen Eocene species of Rluts, widely scattered. Thus there are three in the Ypresian of Alum Bay, four in West Greenland and North American species in the Lance, Kenai, Ft. Lnion and Green River formations. The genus doubles its known species in the early. Oligocene, being especially well represented in southern France, but also recorded from the Tyrol, the Baltic amber, Italy, Carniola and Styria.

In the Miocene Rhus seems to have been as abundant, as well differentiated, and as widely distributed as it is in the existing flora, for over sixty fossil species have already been described. The records embrace all European countries where Miocene plants have been found as well as Iceland and the following North Imerican localities:-Maryland, Virginia, Colorado, Yellowstone Park, Ilaho, Nevada, Oregon and California. Only a small number of Plincene species are known and these are recorded in Spain, France, Italy, Germany and Slavonia.

Three Pleistocene species are recorded, 2 from Japan and one from China, all chesly related to still existing species of that region. Engler ${ }^{55}$-ome years ago reviewed the geological records of Rluts and conclurled that most of the then known fosil species belonged to the section Trichocarpx (in the existing flora with over a score of species mostly confined to North America and eastern Asia ). or tire section Gerontogere (with 75 existing species mostly confined to Sulth . Ifrica). A few fossil forms he considered as representing the section Venenatie, which has abnut if existing species in North ${ }^{35}$ Engler, A., Bot. Jahrb., Bd. I, I881, pp. 413-419. 
and South America. The other sections into which the genus is subdivided were not recognized among the fossil forms.

The allied genus Cotinus with two or three existing species in Eurasia and North America is probably represented by some of the fossil forms referred to Rhus, c. g., Saporta considers Rhus antilopum Unger from the Aquitanian of Kumi as a species of Cotimus. This author has also described Cotinus palcocotinus, and Cockerell has described Cotinus fraterna from the Miocene of Florissant, Colorado.

The genus Pistacia with five existing Mediterannean species and one each in eastern Asia and Mexico has about fifteen known fossil species the oldest, of doubtful value, coming from the Raritan of Staten Island. A second Cretaceous species is found in the Laramie of Colorado. Europe enters the record with a Ypresian species from Alum Bay. There are three Oligocene species in France and seven Miocene species in France, Bohemia, Styria, Galicia, and Transylvania. There is a Pliocene species in Styria, an extinct Pleistocene species on the Island of Madeira, and the existing Pistacia lentiscus Linné in the Pleistocene of the Island of Santorin.

The genus Anacardites Saporta (Anacardiophyllum) has been used as a form-genus for fossil Anacardiaceæ of uncertain generic relationship. As used by Saporta it represented fossil forms resembling existing species of Manyifera, Anaphenium, Spondias, Comocladia, Holigarna, etc., but not determinable with certainty. Heer has described a supposed species of Anacardites from the Atane beds of West Greenland. There are two species in the Sparnacian and one in the Ypresian of France and seven well marked species in the Wilcox. There are two or three Oligocene species in France and Germany and two or three Miocene species in France and Styria. Felix has described petrified wood from the Eocene of the Caucasus which he refers to Anacardionylon, a type also represented in the Oligocene of Antigua in the American tropics (species compared with existing genus Spondias).

The floral genus Heterocaly.x Saporta (Trilobium Saporta, Elaphrium Lnger, Getonia Lnger) which occurs at a number of horizons in the Oligocene of France, Croatia, and Styria is represented by a second species in the IVilcox. Saporta compared it with the South 
American genus Astronium but Engler (op. cit.) considers it most like the Malayan genus Parishia.

The genus Mctopium, not certainly recognized heretofore, has a well-marked species in the Wilcox. Several Tertiary woods are describerl hy L Leer as Rhuidium and saporta has le-cribed a species of Schinus from the French Oligocene (Gargas) which is wrongly determined according to Schenk (p. 54I).

The genus Spondiacarpum has a species in the early Eocene of France and a sccond in the Iquitanian of Rhenish ['russia. Recently. Fritel has described leaves from the Aquitanian of France which he calls Scmecarpitcs that are very close to the existing genus Semecarpus which has about 40 species ranging from India to Australia.

The family Ilicacex (Aquifoliacex) is a relatively small one comprising only five genera and about I80 existing species. They are shrubs or trees with alternate, simple, entire or toothed, often coriaceous leaves. The flowers are small, dioecious and hypogynous. The fruit is a drupe with a thin fleshy sarcocarp enclosing as many crustaceous nutlets as there are carpels. The genus Ile.r Linné to which all but seven of the existing species are referred is found in all tropical and temperate regions of the world except western North America, Australia, New Zealand and New Guinea. The remaining genera of the family are Oncotheca Baillon with a single species in New Caledonia, Nemopanthes Rafinesque with a single species in temperate North. Inerica, Sphenostemon baillon with two species in New Calerlonia, and B yronia Endlicher with three species, one in Tahiti, one in the Hawaiian Islands and one in Australia. This molern distribution is a certain indication that the fandy has an extended geologic history.

Over a hundred fossil species have been referred to the genus Ile.r. At least thirteen species are recorded from the Upper Cretaccous. All but one from the Turonian of Bohemia are from the western hemisphere and include two in the Raritan formation, three

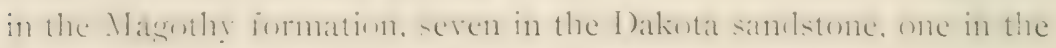
Atane and two in the Patoot beds of western Greenland.

There are about fourteen Eocene species including four in the Wilcox, one in the Ypresian of England, one in the Fort Union, four in the Green River beds, five in Greenland, one in Alaska and one in 
Australia. There are over a score of Oligocene species including one from Chili that may even be of Eocene age. The lower Oligocene or Sannoisian has eleven species in France, Tyrol, Saxony and Prussia and includes three species of flowers described by Caspary from the Baltic amber. The Middle Oligocene or Tongrian has six species in France, Italy, Germany and Styria and there are seven species in the Upper Oligocene (Chattian) of France, Bohemia and Greece. Upwards of fifty species have been described from the Miocene of Europe and Asia, and from New Jérsey, Colorado and California in this country. The most prolific Miocene area is that of France. About ten species are known from the Pliocene of Spain, France, Italy, Prussia and Asia Minor. One fossil and four recent species are found in the Pleistocene of Virginia, North Carolina, Alabama, Kentucky and the Island of Madeira. In addition to the fossil forms referred to Ilex, two Miocene species from Italy and Styria are referred to the genus Nemopanthes and four forms from the late Oligocene or the Miocene of Prussia, Styria, Croatia, Bohemia and Greece are referred to the genus Prinos Linné, which is usually considered a section of Ilex. The four species from the Wilcox that are referred to Ilex are represented in the collections by a small amount of mostly poor material and are without special significance.

The family Celastraceæ includes about 40 genera and upwards of $f 00$ existing species of trees and shrubs with opposite or alternate, simple, persistent or deciduous leaves and capsular or drupaceous fruits. The three large genera Euonymus, Celastrus and Gymmosporia are practically cosmopolitan and several additional genera localized in the modern flora were cosmopolitan in the Tertiary.

The following I2 genera with over roo species are confined to America: Framnhofera, Mortonia, Glossopetalum, Schaefferia, Goupia, Maytenus, Pachystima, Zinowiewia, Plenckia, Wimmeria, Gyminda, Rhacoma. The genera Glyptopetalum and Tripteryium together with five species are confined to Asia. The genera Hypsophila. Denhamia and IIcdraianthera together with seven species are confined to Australia. And the following ten genera with about 60 species are confined to Africa or Madlagascar: Putterlickia. Catha. Pterocclastrus, Polycardia, Ptclidium, Cassine, Ela odendron, Maurocenia, Schrebera and Lauridia. 
The family is definitely represented in the Cretaccous by at least five genera and is an important element in most Tertiary floras. The ollest known genus is the form-genus Celastrophyllum propused by Gæppert. Five well-marked species occur in the Patapsco formation (Albian) of Virigina and Maryland. At the base of the Ciper (retaceous, particularly in North America, a large number of species occur. Upward of thirty have been described of which number two are recorded from New Zealand and two from the Cenomanian of Niederschena in Saxony. There is a species in the Atane beds of Greenland and three in the Patoot beds. The remainder occur in the United States and have the following distribution: ten in the Raritan formation of New Jersey and Maryland, twelve in the Tuscaloosa formation of Alabama, two in the Magothy formation of New Jersey and Naryland, two in the Middendorf berls of South Carolina, seven in the Dakota sandstone, and two in the Black Creck formation of North Carolina. There are ten Eocene species-seven in the hasal Eocene of Pelgium, one in the Ypresian of Fingland and two in the Claiborne group of the Mississippi embayment. There are five Miocene species in Italy, Bohemia and Styria; a Pliocene species in Italy; and four Tertiary species from the Islancl of Tava. Another form-genus is Celastrinites Saporta which has four species in the Paleocene of France, one in the Denver formation of Colorado, another in the Livingston formation of Montana, and a seventh in the Miocene of Florissant, Colorado.

The genus Celastrus Linné is the largest fossil genus of the family and its history shows that while its present center of distribution is in the njlands of southeastern Asia and the Fast Indies the ancestral stock was cosmopolitan and very abundant in the Tertiary of . Incrica ancl Europe, with a strong probability that it originated in the former area at the dawn of the Upper Cretaceous or somewhat earlier. The oldest known species, Cclastrus arctica Heer, is frund in the Raritan and Magothy formations of New Jersey and Maryland and in the Patoot beds of Greenland. No less than thirty specic of Celastmus have been described from the Eocene. These inclurle six Ypresian species from England, five species in the Wilcox flora, one in the Denver, ten in the Fort Union, one in the Kenai of Alaska, three from Greenland and four from Australia. 
There are also about thirty Oligocene species, all European, and including remains in the Baltic amber, in France, Switzerland, Germany, Austria-Hungary and Greece. There are at least a dozen species in the Chattian of Bohemia. Over fifty Miocene species have been described ranging throughout Europe, in eastern Asia, and in Virginia, Colorado, Idaho and Oregon in this country. About a dozen Pliocene species have been described from Spain, France, Italy and Sicily.

The genera Cassine Linné and Pterocelastrus Meissner both now confined to South Africa and Madagascar, each has a fossil species in the Miocene of Bohemia. The genus Pachy'stima Rafinesque, with two existing species in North America, has an Upper. Cretaceous species in North Carolina and a Miocene species in Colorado.

The genus Maytemus Feuill, with about 70 existing species of the tropics and subtropics of South America has a well-marked species in the Wilcox flora. There are two species in the early Tertiary of Chili, one in the late Oligocene and three in the Miocene of southeastern Europe.

The monotypic genus Gyminda Sargent confined to Florida and the West Indies in the existing flora has a doubtfully determined fossil species in the Magothy formation of the Atlantic Costal Plain. The genus IIcrotropis Wall., with 9 or to existing species of the mountains of southeastern Asia from India to China and Japan, has a doubtfully determined form in the early Pliocene of Italy.

A well preserved flower in the Baltic amber is described by Conwentz as Celastrinanthium Hauchecomei.

The genus Elcodendron Jacquin, with about 25 existing species confined to South Africa, has a considerable geologic history. Four Upper Cretaceous species have been described-one from Australia, one from the Dakota sandstone, and two from the Magothy formation of the Atlantic coast. There are six Eocene species showing that the genus was represented in New Zealand (?), Australia (?), Alaska, the Ipresian of England and the Fort Union of the Rocky Mountain region. There are five Oligocene species in the Tyrol, Bohemia and Transylvania ; nine Miocene species in France, Switzerland, Italy, Prussia, Bohemia and Styria; and four Pliocene species in Italy. 
The remaining genus known in the fossil state, Euonymus Linné, has about sixty existing species widely distributed throughout the northern hemisphere but most numerons in the Asiatic tropics and in China and Japan. L pwards of thirty fossil species are known, being based upon both fruits and leaves. There are four well-marked Eocene species all of which are confined to North America where they are represented in West Greenland, in the Fort Union and (ireen River beels of the Rocky Mountain region, and in the Milcox of the Mississippi embayment. The species of the latter region is a very abundant and characteristic form. There are four or five Oligocene species of Euonymus recorded from Bavaria, the Tyrol and Bohemia. The twelve Miocene species occur in France, Prussia, Bohemia, Styria, Croatia, and Hungary. There are four Pliocene species in (iemany, Italy, and Slaronia; and two still existing spe:iés occur in the Pleistocene of France.

From this very brief survey of the fossil history of the Celastracex it is seen that there is a probability, similar to that shown by so many other families of Dicotyledonx, that the ancestral stock originated in the western hemisphere.

The family Sapindacere consists of about II 8 genera and over one thousand existing species of trees or shrulss with alternate, pinnate, exstipulate, persistent, or deciduous leaves and drupaceous or capsular fruits with crustaceous mostly solitary seeds. About one third of the genera are lianas. Most of the family is confined to tropical and subtropical regions and about 23 per cent. of the genera (27) and 34 per cent. of the species (345) are confined to America. There are more genera ( 30 ) confined to the African region but only about one fifth as many species (75).

The genera Cardiospermum, Schmidelia (Allophylus) and Sapindus are found in all tropical countries. The genus Paullinia with over I 20 exi-ting species while mostly. American is present in Ifrica and Madagascar. The genus Dodonca with over 40 species in Australia has one or two forms found in all tropical countries and a

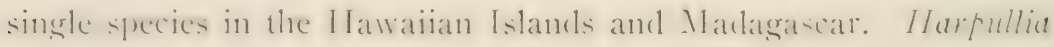
is common to Asia, Africa and Australia. There are two genera with alment fifteen species confined to Instralia, four genera with 66 species ranging from Asia to Australia, Io genera with 22 species 
confined to the East Indies, two genera with 20 species confined to Polynesia and 6 genera with 35 species ranging from Malaysia or the East Indies to Australia. It is quite obvious from these few facts regarding the existing distribution that the family is an ancient one and that there has been an extensive evolution of both generic and specific types in relatively modern times in the American tropics on the one hand and in the Malaysian region on the other.

The fossil record while much less complete than might be wished includes at least 13 genera of which six are extinct, and about 160 species, by far the largest number being referred to the still existing genus Sapindus which appears well differentiated and widely distributed at the dawn of the Upper Cretaceous. There are about ten Upper Cretaceous species of which all but four occur in pre-Senonian strata. Thus there are two in the Perucer beds of Moravia and Bohemia, one at Niederschœna in Saxony-all Cenomanian. Two in the Atane and one in the Patoot beds of West Greenland. Two in the Dakota group; two in the Tuscaloosa formation of Alabama, one in the Middendorf beds of South Carolina, one in the Woodbine formation of Texas; two each in the Raritan and Magothy formations of the Niddle Atlantic states, one in the Montana group and two in the Laramie. I have given this Upper Cretaceous distribution in some detail because of the special interest attached to the deployment of the Upper Cretaceous Dicotyledonæ. It should be noted that seven of these Upper Cretaceous forms are North American. There are over thirty Eocene species of Sapindus of which two thirds are North American. The genus is very abundantly represented in both individuals and species in the coastal floras of the Wilcox group from which I have described no less than 9 species. There are four species in the overlying Claiborne group. Species of Sapindus are equally common in the Rocky Mountain province in the Denver, Fort Union and Green River beds. There is an Eocene species in (rrecnland and one each in New Zealand, Australia, Tasmania and Chili. There are four undescribed species in the Ypresian of England and a fifth in beds of the same age in Hungary. There is an Upper Eocene species in France and a second in Oregon.

There are six or more Oligocene species well distributed in Eu- 
rope to which continent their discovery has thus far been confined. There are over 30 . Miocene species found throughout sombern Europe, in eastern . Isia, and in North America (Colorado, Oregon and Yellwwisne I'ark). The eight or ten Pliocene species are confined to southern Europe.

In addition to the genus Sapindus there are several form-genera derived from the same root. Thus Sapindophy'llum has been applied to two species from the Albian of Portugal (?). To it are also referred a Cenomanian and a Chattian species from Bohemia and a Tertiary species from Japan. The term Safindoides has heen used hy Perkins for Sapindus-like fruits preserved in the early Tertiary lignites of Brandon, Vermont, from which eight species have heen described. In some respects the most interesting genus is Supindepsis Fontaine represented by three abundant and well preserved species in the Patapsco formation (Allian) of Maryland and Tirginia one of which is also present in the Fuson formation of the Plack Ilills, and which I have shown to be very probably ancestral forms of the genus . I atayba Aublet (Cupaniex) which has upwards of two score existing species in the tropical and subtropical regions of America. This well-marked type suggests the interesting question of how early in the Mesozoic the ancestors of many modern genera may have been present in equatorial America.

The genus Paullinia Limé which has about 122 existing species mostly confined to the American tropics but sparingly represented in Airica and Madagascar, has an ()ligocene species in Prussia and two early. Miocene species in southeastern France and Bohemia.

The genus Thouinia Poit, which in the modern flora has about I5 species confined to the West Indies and Mexico, is representerl ly an early Tertiary, probably Eocene species, in Chili. The genus Cephelium I inne with over a score of existing species in southeastern Asia is recorded hy. Linger from the Ayutanian of firece and by Geyler from the Tertiary of Borneo.

The genus Kolreuteria Laxm, is represented by two Chinese species in the existing flora. In the fossil state it is reorded from the Tertiary of the Island of Sachalin, from Spitzlergen and from ${ }^{36}$ Derry, Mrd. Geol. Surw, Lower Cretaceous, pp. 467-474, Pl. 83-88, I9I I. 
Switzerland and Baden. Felix has described a genus, Schmideliopsis, based on fossil wood from the Oligocene of the Island of Antigua, very close to the existing genus Schmidelia Linné which has upwards of a hundred existing species in all tropical countries.

The modern Cupaniex are represented in paleobotanical literature not only by Cupania but by species of Cupanites and Cupanoides. The latter generic term was proposed by Bowerbank for cupaniaceous fruits and seeds of which he described several characteristic species from the Ypresian of the Island of Sheppey. Similar forms have also been recognized in the Miocene of Carniola and in the Pliocene of Italy. The genus Cupania Linné has about 35 existing species confined to the American tropics. Several Ypresian species from the south of England have been referred to it by Ettingshausen and it has also been recorded from the Miocene of the Island of Sachalin. The greater number of Cupania-like forms have, however, been referred to the genus Cupanites Schimper. Nine or ten species have been described and with the exception of extremely douhtful forms from the Upper Cretaceous of New Zealand and the Eocene of Australia, the oldest authentic occurrences are the two species of the ITilcox flora. There is a third species in the overlying Claiborne group of the Mississippi embayment. The oldest European form is one from the late Oligocene of Styria. In the Miocene, species are recorded from Germany, Bohemia, Austria, Croatia and Hungary.

The genus Dodonca Linné often made the type of a distinct family, the Dodonacex, has about fifty existing species of which four fifths are Australian. Dodonca riscosa Linné is cosmopolitan in the tropics and there are one or two additional species in the American tropics as well as one in the Hawaiian Islands and another in Madagascar. The genus (including Dodoncites) was evidently willespread in former times and upwards of a score of fossil species, based on both leaves and fruits, have been described. The oldest known forms are two species in the Ipresian of the north of Englant and the two contemporancous species in the IVilcox, which are represented by both leaves and characteristic fruits. There are five ()ligocene species in France, Tyrol, Bohemia and Styria; and ten 
Miocene species in I'rusia. Baden, Switzerland, Bohemia and croatia. A well-marked species occurs in the Claiborne (Lutetian) ranging along the Claiborne coast from northeastern Georgia to central Louisiana.

It is impossible from the known facts to discuss the place of origin of the family, but it is obvious that certain genera were evolved toward the close of the Lower Cretaceous in equatorial America and have inhalited that or arljacent areas throughout the long stretih of time down to the present.

The order Rhamnales includes about $\mathrm{I}, 000$ existing species of shrubs, trees and vines about equally divided between the families Rhamnacere and Vitacere. It closely parallels the Sapindales in its flural development hut is distinguished by the mostly tetractelic flowers with opposite stamens and often lacking a corolla. The leaves are simple and typically alternate. Of the two families only the Rhamnacere is represented in the Wilcox flora.

The family Rhamnacex (Frangulacex) includes 47 genera and about 500 species of shrubs and trees mostly of the tropics but with sercral genera extending for considerable clistances into the temperate zone, the genus Rhammus in particular heing mostly extratropical in the northern hemisphere. The genera Zisyphus, Adclia and Goutania are found in all tropical countries. Almost half of the genera are common to more than one continental area. America has the greatest number of peculiar genera (15) with about 85 species. Two monotypic genera are confined to Asia, five genera including the large genus Phylica I inne together with about 70 species are confined to Africa and five genera including the two large genera Sp yridium Fenzl, and Cryptandra. Smith in all with about 70 species are confined to Australia.

Ten or eleven genera, of which five are present in the Wilcox flora, are found fossil, the three largest being Rhamnus, Paliurus and Ziryphus. The genus Rhamnus Linné which is cosmopolitan in the northern warm temperate and subtropical zones has about seventy existing species. There are considerably over one hundred fossil species, mostly well characterized with simple often entire

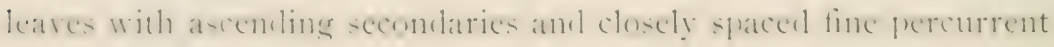


nervilles. There are a dozen or more species described from the Upper Cretaceous, the genus appearing in the Cenomanian in both Europe (Niederschœna, Saxony) and America (Raritan formation). There are six species in the Dakota sandstone, two in the Magothy formation, one in the Atane and two in the Patoot beds of Greenland. The genus is represented in the Montana group and the Laramie formation of the Western Interior and in the Senonian of Westphalia. There are about thirty Eocene species, the majority being North American. Species of Rhammus are very common in the Raton and Denver formations along the Front Range of the Rocky Mountains and from the base to the top of the Wilcox. There are four species in the Raton, eight in the Denver and six in the Wilcox. The genus is also well represented in the later Eocene along the Pacific coast and in western Greenland. In Europe only a single species is recorded from the Paleocene. The Ypresian which is synchronous with the Wilcox has three species in the south of England.

There are eleven or twelve Oligocene species in France, Prussia, Tyrol, Italy, Dalmatia, Styria, and Greece and a single undescribed species in the Apalachicola group of Florida. There are over two score Miocene species, Rhammus being especially abundant in the Miocene of Switzerland, Italy, Bohemia, Prussia and Styria. It is also present at this time in Iceland, Spitzbergen, Nanchuria and Sachalin Island. In this country there are species in British Columbia and in Colorado.

There are about thirteen Pliocene species, no less than nine being recorded from Italy and there is one known from the Island of Java. There is an extinct species in the Pleistocene of Hungary and a recent species in the Pleistocene of the Island of Madeira. In addition to the species referred to Rhammus the form-genus Rhamnites Forbes founded on three species from the Eocene of the Isle of Mull has two American Upper Cretaceous species found in the Raritan, Tuscaloosa, Magothy and Dakota formations. There is a species in the Fort Union and another in the Wilcox. The genus Rhammacinium of Felix is based on petrified wood. It contains five or six species found in the Eocene of the Caucasus, Texas, Saskatchewan and the Miocene of Yellowstone Park. 
The genus Paliurus Jussieu with only two existing species ranging from southern Europe through southem. Isia to China and Japan was cosmopolitan in former times. Upwards of 40 fossil species have been described. At least twelve are known from the Upper Cretaceous, all confined to the North American region. There are two each in the Raritan, Nagothy and Laramie, five in the Dakota and one each in the Eutaw formation of Georgia, in IV est (irecnland and Vancouver Island. There are ten Eocene species also confined to North America. Two of these are found in the Fort Union and there are three each in the Denver, in western Greenland and in the Wilcox. The leaves are not common in the Wilcox but the characteristic peltate fruits are not uncommon. The oldest European forms are two species in the Oligocene of France and there is a well marked species in the ()ligocene (Vickshurg group) of Lonisiana. The thirteen Miocene species are found in Asia (Siberia, Sachalin). Europe (Switzerland, Baden, Germany, Bohemia, Italy, Styria and France), and North America (Colorado and Oregon). The presence of numerous species of Paliurus in the Lpper Cretaceous and Eocene of North America and their absence on other continents before the Oligocene renders it very probable that the genus originated in the western hemisphere.

The genus Zizyphus Jussieu with about forty existing species largely shrubs, often prostrate or scrambling, and rarely small trees. is mostly. Indo-Malayan in its distribution but is represented by a few species in the tropics of eastern Asia, America, Africa and Australia. There are over fifty known fossil species and as in the genus Paliurus the ten Upper Cretaceous species are confined to North America. They are found in the Raritan and Magothy formations of New Tersey and Maryland, the Entaw formation in Georgia, the Tuscalorsa formation in . Halama, the Woollhine formation in Texa the Dakota sanditone of the Mest, the I'atoot herls of (ireenland and the Upper Cretaceous of Alaska. There are about twenty: Encene species including the two common and characteristic species of the Wilcox and one in the overlying Claborne of the embanent region, five in the Denver, three in the Fort L nion, two in the firen River, one in Alaska and one in West Greenland. There are two 
Paleocene species in France and Belgium, four Ypresian species in the south of England and a Lutetian species in France. There are eight Oligocene species very common in deposits of this age throughout Europe. Over twenty species have been recorded from the Miocene of Colorado and California in this country, from France, Sivitzerland, Germany, Italy, Austria-Hungary, and Russia in Europe, and from Japan and Java in Asia. There are three or four Pliocene species in Europe. While the evidence is not so clear as in the case of Paliums there is a possibility that Zizyphus too is of occidental origin.

The genus Reynosia Grisebach with only two existing coastal species ranging from the Florida keys through the IVest Indies has two characteristic species based on leaves in the Wilcox flora and a third species based on the petrified wood in the overlying Claiborne deposits of Texas.

The genus Berchemia Neck. has about a dozen existing species, ten of which are confined to eastern and southeasern Asia. There is one in eastern extratropical North America and one in eastern Africa. This distribution could not have been brought about except by the agency of a cosmopolitan Tertiary range. While the specific differentiation of Berchemia is limited to five or six fossil forms these are very common and wide ranging. The earliest occurrences are North American and include the Raton, Denver and Fort Union formations of the Rocky Mountain province. The genus makes its apearance in Europe during the Oligocene and is common throughout that region in the Miocene, becoming restricted to southern Europe (France, Italy, Sicily and Slavonia) during the Pliocene.

A species of Hoveniphyllum supposed to represent the existing genus Hor'nia Thunberg with a single existing species in southeastern Asia, is present in the Plio-Pleistocene of Japan. The genus Colubrina Brongniart with 5 existing species in tropical America and one in southeastern Asia is recorded from the Miocene of Bohemia.

The genus Pomadcris Labill with about 24 existing species confinerl to Australia and New Zealand has two species in the Eocene of the former region and three species (Pomaderrites Ettingshansen) in the Miocene of Prussia, Bohemia and Styria. 
The genus Ceanothus Linné with about forty existing species continerl to North. Imerica has included numerous fossil species sulsequently referred to Paliurus or Zizyphus. There are four recorded from the Upper Cretaceous of Greenland, New Jersey, Vanconver Island and Westphalia; two Eocene species recorded from Greenland and British Columbia; a Miocene species in Prussia, Switzerland and Italy; and a Pleistocene species in Kentucky.

The next order, the Malvales, includes nine families and about I, Noo existing suecies. The Tiliacer, Sierculiace and liombacace are the only ones represented in the Wilcox flora. The largest modern family, the Malvacex with over Soo species, many of which are herbaceous and range from $65^{\circ}$ North latitude (Russia) to $45^{\circ}$ South latitude (New Zealand), is not represented in the IVilcox. The order displays somewhat uneven or but little understood phylogenetic characters but is evidently allied to the succeeding order, the I'arictales, through the family. Flecorpaceat. These inerualities of evolution are shown among other ways by the complete syncarpy in the Tiliacere associated with an inclefinite number of stamens and ly. the complex arrangement of the stamens in the sterculiacea associated with more or less incomplete union of the carpels. Both the leaves, flowers and fruits exhibit a wide range of variation throughout the order.

The family Tiliacex, represented in the Wilcox flora by a single, not very common form of Grewiopsis, has about 35 genera and 370 exinting species mestly of tropical lands and shering two center-at differentiation and distribntion-one surromnding the lndian ()ean and the other in morthem south . Anerica. The geolugical history is confined to the four genera Tilia (or Tilicphyllum), Growia, Grawiopsis and Apcibopsis. ${ }^{37}$ The genus Tilia Linné with IS or 20 widely. distributed existing species in the north temperate zone (absent in western North America and central Asia) has furnished about 25 fossil species based upon both leaves and fruits, the oldest known being from the North American Eocene. There are no conclusive Oligocene records except two French species, but about fifteen Mio-

${ }_{37}$ The genus Luhea has been deseribed from the Eocene of Sézanne (Langeron) and from the Oligocene of Ménat (Laurent), both French Incalities. 
cene species are found in North America, Europe, Asia and the Arctic regions. There are five Pliocene species recorded from Europe and Japan and six Pleistocene species in Ontario, New Jersey, France, Germany, Holland and Denmark. The genus has apparently had its existing range since Miocene time.

The genus Grecuia Linné has about 90 existing species ranging from Arabia to China and Japan and through Malaysia to Australia, and from Abyssinia to South Africa. About fifteen fossil forms have been described, the oldest known, five Eocene species, coming from western North America. There are two Oligocene species in Europe and about six Miocene species in Oregon, Spitzbergen and throughout Etrope. The larger number of Grcwia-like fossil forms are, however, referred to the genus Growiopsis of Saporta. Six of these are from the Upper Cretaceous and all are confined to North America, a very significant fact since several of them are especially well marked. They are found in the Magothy formation of the east coast, the Tuscaloosa formation of the south coast, and the Dakota Montana and Laramie formations of the western interior. There are about six Eocene species in the Denver, Lance and Fort Union: one in the Wilcox and one in the Claiborne of the Mississippi embayment region, six in the Paleocene of France and one in the Ypresian of England. There is also a Miocene (?) species recorded from Yellowstone Park. While it is quite possible that some of the fossil records ascribed to the genus Populus are those of Grewia or its ancestral stock, it seems clear that the latter genus or its immediate ancestors were common in the Upper Cretaceous and Eocene of North America.

The fourth fossil genus of Tiliacex is Apeiobopsis $\mathrm{Heer}^{38}$ named from its affinity with the existing genus Apciba Aublet which has five or six species confined to tropical South America. Apeibopsis includes not only leaves but very characteristic fruits. To it are referred somewhat doubtfully determined leaves from the Upper Cretaceous Dakota sandstone and Atane beds. There are about fourteen Tertiary species inclucling a basal Eocene form from Wyoming, two Ypresian forms from England, a species from WVest Greenland

38 To it should probably be referred the Arctic forms described by Heer as Nordenskioldia.

PROC. AMER. PHIL. SOC. LIII, 2 I4, N, PRINTED JULY I3, I9I4 
three species in the lignites of Brandon, Vermont, two Oligocene species from Italy and five Miocene species from France, Switzerland and Bohemia.

The family Bombacacer ${ }^{30}$ with 20 genera and about 120 existing species is confined to the tropics and principally to the American tropics. The only known fossil forms are those of the genus Bombar or the allied Bombaciphyllum and Bombacites. Bomba.r Linné has about fifty existing species, all large tropical trees, and almost confined to America. There is a single species in Africa, about six in southern Asia and one in Austalia. The fossil species number over twenty, the oldest known ${ }^{40}$ being a common form in the Perucer beds (Cenomanian) of Bohemia and Moravia. There are three species in the Ipresian of sonthern England and two we.lmarked forms in the Wilcox flora. There are five additional Eocene forms of which three are from Chili and two from eastern Australia. There are five Oligocene species recorded from France, Saxony, Bohemia and Carniola. The genus is represented in the early Oligucene (Sannoisian) of southeastern France not only ly the foliage but by beatifully preserved fowers so that there is little ground for questioning the correctness of the identifications. There are five Miocene species in Bohemia, Croatia and Styria.

The family Sterculiacere includes about 5 genera and 800 existing species of mostly tropical shrubs and trees with prevailingly large. simple or digitately lohed or divided leaves: the flowers ate sometimes apetalous and differ from those of the Malvacen in their 2-celled extrorse anthers. Syncarpy is more or less complete.

The Sterculiacex of the existing flora are found on all the continents except Europe. The genera Sterculia, Helicteres, Melochia, Buctuncria and Hermannia have species in both the eastern and western hemispheres. The geologic history of the family extends back to the base of the Upper Cretaccous but is confined to a relatively few number of genera. The most abundant of these is the genus Stcrulia Linné, which in the existing flora has about one

${ }^{30}$ Ettingshausen, "Ueber die Nervation der Bombaceen," Densk. $k$. 1kad. Wiss. Wicn. Wath. Nat. Cl., Band It, 1858, pp. 49-62, Pl. I.-XI.

so An Albian species of Bombax described by Fontaine is entircly valucless. 
hundred species of large leafed trees. They are divided into three tribes named from the habit of the leaves the Digitatx, Lobatx and Integrifoliz. The first of these range from farther India to Australia with only one or two American species. The second is most abundant in the American tropics but is also found in Asia and Africa and shows many parallelisms between the American and Asiatic forms. It is most abundantly represented in the past history of the genus. The third and largest modern tribe, the Integrifoliæ, has five or six American species and the balance are found in Asia and Africa.

The fossil forms (sometimes referred to Sterculiphyllum) number more than fifty species. Upwards of a score are known from the Upper Cretaceous. These are mostly American and are referable to the tribe Lobatæe which may well have originated in the western hemisphere. There is a species each in the Credneria sandstone of Saxony and the Perucer beds of Bohemia (both Cenomanian) and a third in the Turonian of the latter country. The balance are North American and include species in the Raritan formation, the Cheyenne sandstone of southern Kansas, and in British Columbia, a species in the Patoot beds of West Greenland and six species in the Magothy formation of the Atlantic Coastal Plain and eight species in the Dakota sandstone of the western interior. There are less than a dozen Eocene species, the majority being confined to the lower Eocene. Thus there are three species in the Paleocene of France and another in the Ypresian of England as well as one or two in the Denver and Raton formations of the Rocky Tountain front range. The single large Wilcox species is entirely typical and shows the usual variability in lobation and size. It appears to be filiated with Sterculia Snowii Lesquereux from the American Lpper Cretaceous, and may be exactly matched by sereral existing species. There is a small leafed species in the middle Eocene (Claiborne group) of the embayment which exactly matches the typical Sterculia labmusca Tnger from the European Tertiary and the existing Stcrculia dizersifolia Don. It is closely parallelled by two American Upper Cretaceous species-S. minima Berry and S. mucronata Lespluerenx. There are upward of ten Oligocene species wirlely scattered over Furope and ahout is Miocene species, mostly 
Eurogean, with a single -pecies on the east coast of Asia (Sachalin) and two species in Colorado, one of them especially well marked. There are several Pliocene species in southern Europe.

Two somewhat different species of sterculiaceous capsular fruits from the Wilcox are referred to a new genus, Stcrculiocarpus. The larger of these, S. cocenicus, seems referable to the subfamily Buettnerier, while the smaller, S. sezannclloides, is referable to the Lasiopetalex or Helicterex. Both are very similar to the fruits from the Paleocene of Sézanne referred to the genus Sezannella. The latter genus with two species was described by Viguier from casts of wonderfully preserved flowers as well as fruits from the celebrated Travertins of Sézanne and referred with great certainty to the Lasiopetalere.

The tribe Dombeyex with seven genera and about 75 existing species is almost entirely confined to Africa and the adjoining islands, five or six species of the genus Melhania Forsk, only, ranging from Arabia to farther India. This tribe is represented in fossil floras by the genus Dombcyopsis Unger named from its supposed affinity with the modern genus Dombeya Cav. which has 40 African, mostly Marlagascar, species. Thout 30 species have heen referred to Dombeyopsis. They are liable to be confused with Luhca, Grewia and other forms of the allied family Tiliacer. There are three species in the Laramie Cretaceous, two in the Denver formation, twelve (according to Massalongo) in the Upper Eocene of Monte liskat in Italy, five in the Furopean ( ligocene and six in the Mincene of Iceland, France, Switzerland, Prussia, Silesia and Styria. A Pliocene species is recorded from central France. Fossil wood described as Dombeyorylon is recorded by Schenk from the late Tertiary near Cairo, Egypt.

The Buettneriex are represented by a doubtful species described from the Miocene of Colorado, and probably by some of the fossil forms referred to other genera, $c . g$., some of the palmately veined Ficus-like forms such as Fings ocidentulis and Ficus Silhimperi hoth of which are present in the Wilcox flora. Flowers of Buctincria were reported from Sézanne by Solms-Laubach but this probably

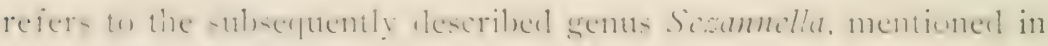
a preceding paragraph. 
The Helicterex are represented by a doubtful species of Helicteres Linné described from the Pliocene of Italy and by forms referred to the existing genus Pterospermum Schreb. or to the extinct genus Pterospcrmites Heer. Over 30 species have been described. There are nine or ten in the Upper Cretaceous all of which are North American, and their combined range extends from New York to western Alabama, throughout the Rocky Mountain and Great Plains province and in the Atane beds of Greenland. There are about a dozen Eocene species all North American except a single species in the Paleocene of France. The American forms extend northward to West Greenland and Alaska. There are two or three species in the European Oligocene and ten Miocene.species throughout Europe and in western North America (Yellowstone Park, California, mouth of the Mackenzie River). A single Pliocene species is recorded from France. It seems probable that this type originated in the western hemisphere since it is so abundantly represented in that region during the Upper Cretaceous and Eocene. The modern species of Pterospermum are, however, confined to eastern tropical Asia.

The order Parietales includes thirty families together with over four thousand existing species, the largest families being the Guttiferæ (775), Flacourtiaceæ (530), Begoniaceæ (425), Violaceæ (400) and Dipterocarpaceæ (330). None of these families are present in the Wilcox flora, where the order is represented by the two families, the Dilleniaceæ and Ternstromaceæ. The Parietales are prevailingly syncarpous and show affinities with the Ranalian plexu: through the Dilleniacex which were formerly referred to that order. The alliance as a whole is a complex one including several divergent lines of development with, on the whole, a gradual increase in floral complexity.

The family Dilleniacere contains I4 genera and about 275 existing species found on all the continents, the genus Tetracera being cosmopolitan in the tropics. The genera Empedoclea, Curatclla, Doliocarpus and Davilla together with 50 species are confined to the American tropics: Hibbertia and Pachynema together with 75 species are Australian, there are five genera with about 25 species confined to the Asiatic tropics; the genus Saurauia (or Saurauja), 
with about 60 species, is common to Asia and South America; and the genus Dillcnia with about 25 species ranges from Asia to Australia: so that on the whole the family is prevailingly oriental in the existing flora.

The fossil record is unfortunately most incomplete, illustrating however a wiler range of the genera in the past in response to milder climatic conditions in both the north and the sonth temperate zones during the Tertiary, and also the fact that several of the modern American genera have been American throughout their known geologic history. Thus Empedoclea with two existing South American species, sometimes made a subgenus of Tetracera, has a fossil form in the eary Tertiary of Chili. The genus Doliocarpus with about 20 recent species also in the South American tropics has two fossil forms in the early Tertiary of Chili. The genus Davilla with 25 modern species in tropical. Imerica is doubtfully represented in the Wilcox flora by Calycites davillaformis Berry.

The genus Saurauja with 60 modern species in South America and Asia has a species in the Paleocene of France, another in the Ypresian of the south of England and a third in the Miocene of Croatia.

The genus Dillenia with 25 existing species confined to Asia and Auntralia is represented by a form in the Paleocene of Pelgium and by some of the Wilcox species referred to the form-genus Dillenites. The genus Tetracera with 40 recent species found in all tropical lands, has two fossil species in the early. Tertiary of Chili, another in the Pliocene of Java and is represented in the VIilcox flora by some of the species of Dillenites. I have recognized five well-marked species of Dillenites in the Wilcox and these appear to represent modern forms of both Dillenia and Tetracera.

Conwenz described three species of Hibbertia, a large Australian senum, in the lialtic amber (Samoisian) but Schenk consiclered that they did not belong to either this genus or even the family.

The iamily 'Temstromacese (Theacese) contains about 16 genera and 175 existines species mostly tropical but extending into the north temperate zone in Dorth America and eastern Asia (Thea. Gordonic and Stciartia). The following seven out of the sixteen genera are confincel to a sincle area: Bennetio Martius with five species inhabits 
the South American strand, Asteropeia Dub. is confined to Madagascar, Thea Linné with sixteen species is confined to southern and eastern Asia, Mountnorrisia Szysz. with two species is a native of the East Indies, the three monotypic genera Visnea Linné, Tremanthera Niuller and Pelliciera Tr. and Planch. are confined respectively to the Canary Islands, New Guinea and Central America. The remaining nine genera, all relatively small, are all found in more than one region. Thus Archytaa Martius has two species in northern South America and a third in the East Indies; Gordonia Ell. has two North American species and fourteen scattered from India to Malaysia; Hamocharis Salisb. has nine American and five Asian species; Steruartia Linné with five species is found in North America and Japan; Taonabo Aublet has 20 species in South America and eight in Asia; Adinandra Jack. has I9 African species and one in Asia; Eurya Thunb. with 36 species and many varieties is confined to tropical America and the East Indies.

This remarkable existing distribution and the pairing of America and Asia as well as the fact that it requires five subfamilies for the reception of only sixteen genera are sure indications that the family has an extended geologic history and that many of the genera were once cosmopolitan. Unfortunately most of this history is unknown.

The genus Stewartia is represented in the Baltic amber by a fine flower (Stewartia kowalowskii Caspary) and by leaf remains from the Plio-Pleistocene of Japan (Mogi). Gordonia has a species in the Pleistocene of Java. The genus Eurya Thunberg, now American and East Indian, has a species in the Oligocene of France (Freziera Swartz). Fossil wood described by Felix and named Temstromiacinium occurs in the Eocene of the Caucasus. Visnea Linné, now confined to the Canaries, has a typical fruit in the Aquitanian of Rhenish Prussia. The genus Temstromia Nuttall (antedated by Taonabo Aublet) has several fossil species, the oldest (Ternstromiphyllum) coming from the Perucer beds (Cenomanian) of Bohemia. It has two species in the Ypresian of the Isle of Wight, one in the Miocene of Bohemia and another in the Miocene of Croatia. I have described four well-marked species of Ternstromites from the Wilcox group and similar forms are present in the overlying Claiborne group (Lutetian). Finally the very abundant species in 
the North American Cretaceous clescribed as Celastrophyllum and already referred to in the discussion of the Celastracex are very probably, in part at least, referable to this family, so that enough is known of the geologic history of the group to confirm at least the statement made in a preceding paragraph that it must have had a long and extended history.

The family Lauracex with in the neighborhood of 1,000 existing species distributed among forty to fifty genera is often placed next to the family Anonacere among the Ranales (c. g., in Engler and Prantl's "Naturlichen Pflanzenfamilien"). It may be noted, however, that the spiral arrangement of floral organs characteristic of the order Ranales is replaced by a cyclic ararngement and hypogny is also replaced by epigyny, so that I follow various students in referring the Lauracex to the order Thymeleales, the other large family of which, the Thymelreacex (not known in Wilcox flora), has about foo existing species, chiefly of temperate. Instralia and the Cape region of Africa.

The seographical distribution of the Lauracee cammot he dispesece: of in a similar simple statement since there are not only many anomalies in the distribution of the existing species but we know st consirlerable a part of the geologic history that our difficultics sem increased therey rather than diminished. For example the existing species of the family are divided into eight tribes, no one of which except the monotypic Eusideroxylere of Borneo is restricted to a single continental region.

The largest of these tribes is the Cinnamomer with upwards of 500 species endemic on all the continents but Europe, and chiefly Asiatic and American. The four genera Persca, Placbe, Notaplecbe and . Mespilodaplue are found in hoth hemispheres: Cinnamomum and Machilus are oriental; while Orcodaphne, Strychnodaphne,

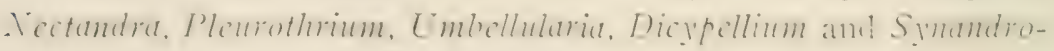
daphne are occidental; the first three being large genera and the last four being monotypic.

The tribe Litsere, with six genera and about 200 species, is represented on all the continents except Europe and Africa. Only 9 of these two hundred species are found in the occident and yet

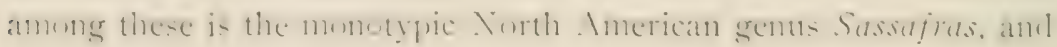


the genus Sassafridium confined to the American tropics. All of the other genera are found on more than one continent.

The tribes Apollonieæ, Cryptocaryeæ and Cassytheæ are found on all the continents but Europe. The Laureæ are Eurasiatic and the Acrodiclidiere are confined to Central and South America, except the genus Endiandra which with I6 species occurs in the East Indies and Australia.

The problem of correctly identifying leaves of the various genera of this family is beset with almost unsurmountable difficulties, not the least of which is due to the wide differences in usage among students of the recent forms where the whole plant is available for study. Long-continued paleobotanical practice has been to refer most fossil leaves that lacked the more apparent characters of Cimnamomum or Sassafras, Persea or Malapœnna, etc., to the comprehensive genus Laurus given at a time when Laurus was used in a comprehensive sense, and sometimes still more generalized by paleobotanists as Laurophyllum for lauraceous leaves of uncertain generic affinity and not necessarily close to the existing species of Laums, in fact they are in general not true species of Laurus. I have departed from this practise of describing new species of Laurus for a variety of reasons foremost among which is the very great affinities between the Wilcox flora and the existing flora of the American tropics, the evidence from the foliage of a large number of genera being coroborated by fruits or seeds or wood anatomy. I have used this similarity with a great deal, perhaps too much, confidence and the result has been that the following stand out as the more important lauraceous types in the Wilcox flora:

Nearly all are seemingly members of the subfamily Persoidex and under this sulpfanily of the tribe Cinnamomere as segregated in Engler and Prantl's "Naturlichen Pflanzenfamilien."

First the genus Cimnamomum, usually readily recognized and certainly represented in our Eocene floras.

Second the genus Pcrsca, represented by the larger and wider forms with the typical venation of this genus.

Third the genus Nectandra, so abundant and characteristic of the existing flora of tropical and subtropical America, represented by several species very close to modern forms. 
Fonrth. I have falled to follow the latest nage in recognizing the genus Ocotea as such, since for obvious reasons it seems better to reognize the genera . Mespiledafhe and Oreodaphne of Nees rather than w regart them as sulgenera of Ooted. The third stubgente of Ocotea,-Strychnodaphne, I have failed to recognize in the Eocene flora of this area.

The only apparent oddity in distribution shown by the Wilcox Liturace in comparison with recent floras of tropical. Imerica is the abundance of (imnumomum, and this simply ardes confirmation to the well-known fact of the cosmopolitanism of this genus in the early Tertiary. Grisebach records only 28 species of Lauraceae in his flora of the British West Indies. Most of these are not coastal forms although many have a wide range from lowlands to mountains. As regards the Latracee those of the Wilcox, which number $3^{\text {o }}$ differem: forms, are more clowely comparable with the more abundant modern representation of this family in northern South America. This receives more or less confirmation from a study of the balance of the Wilcox flora. It would seem from a consideration of all of the facts that the early Eocene floras of the Misissippi embayment are much more like those existing at the present time along the Cariblean sea in Central America and northern South America than they are like those of the West Indies. I do not mean by this that the Wilcox flora has not many points of resemblance to the lowland flora of the West Indies and that of the Florida keys. They contain very many common tyjes, but with the following difference. The Mississippi cmbayment Eocene floras represent a maximum northward extencion of a fora like that which now inhabits northern South America. At the end of the Oligocene with the southward migration of the temperate Mincenc fatma at far as Floricla, this flora retirecl 16) the South . Imerican mainland and the present flora of the West Inties, Forida lieys. liahamas and liemmla represent a later northward migration from that area, a migration in which some of the Wilcox types were left behind.

The existing species of Cimamomum:1 number about fifty. They are onfmed to the Griental tropics exeept for their extensinn into the warmer more humid part of the temperate zone in Japan, and 41 Staub, "Die Geschichte des genus Cinnamomum," Budapest, I905. 
they have their chief center of differentiation in the elevated region of Burma, Siam, Cochin-China and Malaysia, although they are cultivated in all tropical countries and outside the tropics in Europe, Africa and North America. Their fruits are eaten by birds which seed them freely so that they commonly escape from cultivation. Thus Cimnamomum Camphora (Linné) Nees and Eberm. is naturalized throtighout peninsular Florida, and the commercial Cinnamomum zcylanicum Breyn., is readily naturalized in the same manner from the Oriental camphor plantations.

While the data for constructing the geologic history of Cinnamomum are far from complete there are more known fossil than recent species and these show, as in the case with so many plant groups, surprising extensions of range during the Upper Cretaceous and Tertiary. The original home of the genus is unknown for it appears in the early part of the Upper Cretaceous at about the same time in New Zealand, Australia, central Europe, Greenland, North and South America. The European and North American records apjear to be slightly older than the balance and would indicate that the Asiatic region may have been the original home of the genus which spread northeastward across the Behring region to America and northwestward into the European region, the latter largely an archipelago at that time.

The Eocene records include all of the continents except Antarctica and South America. The Oligocene records are chiefly European and African, although the genus is still represented in the Florida Oligocene. During the Miocene Cimamomum was abundant in Europe and present in Asia but appears to have become extinct in North America, at least there are no conclusive North American records. A number of fruits from the Brandon (Vermont) lignites have been referred to (imnamomum but these lignites are in my opinion pre-Miocene in age. The Pliocene records are entirely European and East Indian. The genus appears to have lingered as a common type in Mediterrancan Europe until the changing climates that ushererl in the Pleistocene glaciation caused its extinction, any connecterl distribution with its present ()riental home across sonthwestern . Isia having alrearly been interrupted by the orogenic movements and the development of arid conditions in southwest Asia. 
There are six well-marked types of Cinnamomum leaves described from the Vilen stomp, some of them leing abmulant and generally distributed, and all but two appear to be new to science. In addition buds and flowers that suggest this genus are described under the form-genus Laurophyllum.

There are two species of Persea in the Wilcox flora. Disregarding the fossil forms referred to Laums in a comprehensive sense there are about fifty known fossil species of Persea which is about the number of the existing species. All six of the Upper Cretaceous forms are American where they are widely distributed. By Eocene times they had reached Europe and South America and they are cosmopulitan in the northern hemisphere throughout the Tertiary. being especially abundant in the Pliocene of the Mediterranean region. It would seem as if their Cretaceous origin was occidental, that they spread over the northern hemisphere during the Tertiary and became restricted to southeastern Asia, the Canary Islands and America during the Pleistocene.

The genus Ocotca of Aublet with over 200 existing species is, it seems to me, composite, and I regard Nee's three genera Mespilodaplme, Oreodaplune and Strychnodaplme as distinct. The modern species of Mespilodaphne are confined to South Africa and tropical America. The fossil record is almost entirely merged in the forms referred to Laurus. I have recognized four well-marked species in the Wilcox flora. They are abundant types and some range from the base to the top of the deposits, and along the Wilcox coast from Mississippi around the head of the embayment and westward to western Texas.

The genus Orcodaplune has been recognized in the American Upper Cretaceous and throughout the European Tertiary. At the present time its numerous species are confined to the American tropics. In the Wilcox it has seven well-marked species, which are alumlant individually. some ranging from Missisipgi to Texas and from the base to the top of the Wilcox. The genus is probably of American origin and it has been a member of the flora of the American tropics from the Upper Cretaceous to the present.

The genus Nectandra with about seventy existing species con-

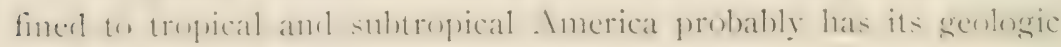


history entangled with the fossil forms referred to Laurus. It occurs in the American Upper Cretaceous and the European and South American Tertiary. There are at least five characteristic Wilcox species some of which were abundant along the Wilcox coasts and some range from the base to the top of the deposits. Like Oreodaphne this genus appears to have been of American origin, becoming cosmopolitan in the Tertiary and restricted to its original home during the Pleistocene, where it is still a vigorous and much differentiated type.

The tribes Eusideroxylex, Litseeæ, Apollonieæ, Acrodiclidieæ, Laurex and Cassytheæ do not appear to be represented in the Wilcox flora although the Litseex are represented in the Upper Cretaceous of the Mississippi embayment area and the Laurex are common in the American Upper Cretaceous.

The tribe Cryptocaryeæ, now largely American, is represented in the IVilcox by a single well-marked species of Cryptocarya. The existing species of Cryptocarya number about 40 of which $\mathrm{r} / 4$ are South American and the balance Oriental. Only two or three fossil species are known. These come from the Tertiary of Australia and the Pleistocene of Java.

The form genus Laurus which serves to render insecure the discussion of the geologic history of the preceding genera includes a very large number of fossil forms of which no less than 25 are Cretaccous, the oldest being from the Albian of France and Portugal. Species of Laurus are abundant throughout North America in the Cenomanian, ranging northward to Greenland and also occurring in Europe and Australia. They have over a score of species in the Eocene and with a similar wide range. The 30 or more Oligocene species are confined to Europe. Over 30 Miocene species are confined to Europe and America and the score of Pliocene species are Mediterranean and largely Italian.

I will mention only one other genus since it definitely shows a past history that is probably typical of a large number of genera of Lauraceæ. The genus Sassafras. ${ }^{42}$ monotypic and confined to North America in the existing flora, belongs to a large tribe-the Litseeæ, which toclay is chiefly ()riental, ranging from Asia through Malaysia 42 See Berry, Bot. Gaz., Vol. 34, I902, pp. 426-450, tf. I-4, P1. I8. 
to Australia. Sassafras has well-marked foliar characters of both form and venation that remler it realily recognizable in the fossil state. Upwards of two score fossil forms have been clescribed. The ollest of these are thee well markerl species in the Patapseo formation (Albian) of the Middle Atlantic slope in Maryland and Virginia. A species is recorded from this horizon in Portugal but the identification is very doubtful as is that of a Cenomanian species decribed from Bohemia. which latter probably represents the genus Stcrculia. In America on the other hand the genus is widespread and well differentiated at the hase of the Cpper Cretaceons, ranging from Greenland along the coast and in the interior to South America and with about a dozen known species. By Eocene times Sassafras had reached Europe ${ }^{43}$ probably by way of the Arctic regions, where it has been found throughout the Oligocene and Mincene. In the Pliocene the European forms harl retreaterl southwarl but remained common in Italy, France and Spain. The glaciation of the Pleistocene catsed their extinction on that continent, the single existing species surviving today in the original home of the genus.

The order Myrtales as developed in the Wilcox flora contains I I species of Myrtacex, 9 species of Combretacere. I species of Trapaceat and I species of Melastomacex, as against over 7,000 species in the existing flora.

The family Myrtacex has over 3,100 existing species separated by taxonomists into 2 subfamilies. The first of these the IIyrtnilee with 32 gencra and about 2,400 species comprises mostly tropical forms of which over 75 per cent. are confined to the western hemisphere. There are over 200 in Asia, one of which extends into southern Europe, about 75 in Africa, about 200 in Australia, and ahout 60 in Oceanica. Nineteen of the genera are confined to Amerio and these inclute the only monotypic genera in the suhfanily, three in number, as well as large and greatly differentiated genera like Myrcia with upwards of 450 species. The two other large genera, Mytus with 1 - s species and I:uchia with about 1,300 species, are the only two genera found on all the continents and in these two

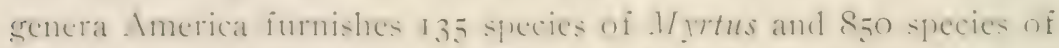

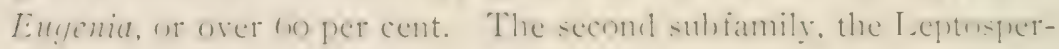

43 A very doubtful form is recorded from Australia. 
moidex, comprises the Leptospermæ with 28 genera and about 700 species and the Chamelenciere with 12 genera and about $6_{5}$ species. Both of these tribes are even more strikingly Australian than the Myrtoidex are American. The Chamnæleucieæ are entirely Australian and mainly confined to western Australia. The Leptosperma have a single monotypic genus in Chili and the distribution of the other members of this tribe suggest the probability that it should be placed in some other alliance, since with the exception of Metrosidcros, which is represented in Africa, and the genus Bacckea which reaches the Asiatic mainland, all of the genera are confined to Australia or the surrounding islands southeast of Asia.

In a recent paper Andrews ${ }^{44}$ has presented some interesting statistics of distribution and an ingenious theory of the history of the family. He considers that the original stock was arborescent or shrubby with entire, simple, opposite, penniveined leaves with dots and intra-marginal acrodrome veins; with the calyx lobes and petals imbricate, probably in fives: flowers regular, solitary or in cymes; stamens indefinite, numerous, free, with versatile, 2-celled anthers; ovary inferior with two or more cells; style simple; fruit inferior, crowned with persistent limb of calyx, indehiscent, succulent or fleshy (rarely dry); albumen none; cotyledons thick and fleshy, with a short radicle.

From the character of Cretaceous climates this or some other theoretical prototype flourished in a mesophytic environment. Among modern groups the nearest approach to this theoretical stock is furnished by the Myrtoidex which are fleshy fruited, most numerous in species, and widely spread in the equatorial regions, with over 75 per cent., however, confined to America. The existing Myrtaceæ with capsular fruits representing the extreme of specialization in the fanily are Australian while the Chamelanciex standing in an intermediate position between the two preceding groups are almost wholly confined to western Australia.

These are the facts of modern distribution. Their interpretation may be various. Andrews (op. cit.) from a study of the present distribution, genlogic climates and the geological history of the Austra-

44 Andrews, E. C., "The Development of the Natural Order Myrtaceæ," Proc. Linn. Soc. N. S. Wales, Vol. 38, Pt. 3, 1913, pp. 529-568. 
lian regime concludes that the I-eptospermonilea originated from the Myrter, and that the Cretaceous forms were widespread which latter was undoubtedly the case. That before the separation of Australia from the Asiatic mainland fleshy-fruited forms found themselves in a region of warm moist climate but relatively poor soil and that it was this edaphic factor that was the principal stimulus to the cilïerentiation of the I,eptospermoiclea. which with the exception (if the genus hetrosideres show adaptations to poor soil and temperate or dry climates and this exception explains the relatively wide distribution of Metrosideros from Asia to the Fiji Islands. The Eucalyptus forms according to the view of this student were derived from Metrosideros after the separation of New Caledonia from Australia and the latter continent from Asia. To support this latter print Indrews is obliged to consider all of the Cretaceous identifications of Eucalyptus and all of the Tertiary identifications outside of Australia as equally misleading. With regard to the presence of Eucalyptus in North America I think this contention to be not unlikely, for althugh in accordance with paleobotanical usage, I have identified numerous forms of Eucalyptus in the North American Ipper Cretaceous. I have long thought that these leaves represented ancestral forms of Euycuia or . M yoir. but have hesitated suggesting any change in nomenclature from the havoc it would play with stratigraphic paleobotany.

The supposed American Cretaceous fruits of Eucalyptus have long since been shown to be referable to I) ammara-like forms and in my studies of the Tertiary flora I have scrupulously refrained from referring any of the numerous mytacens leaves to the genus Emilyptus. Regarding the possible occurrence of Eucalyptus in Eurupe I am not sure that the irlentifications of I Ieer, L nger and Fitingshausen are erroneous. Certain remains considered as Eucalyptus frutis secm very consincing from the published figures and there is not the slightest dumbt that the other great modern . Instralian alliance-the Proteacex-was represented in both Europe and America during the Cretaceous and Tertiary. There is one additional argument against the Cretalcen- radiation and the paleolutanical determination of Eucalyptus and that is the great persistence of the jeculiar jurenile. prpmite, corlate, sessile and horizontal leares which 
must represent an ancestral character of long standing before the evolution of the falcate leaves of the genus with twisted leafstalks and other xerophytic features. ${ }^{45}$

I have divelt at some length on this question because of its phylogenetic importance and the possible bearing of the Wilcox flora on this point. In considering the morphology of the existing species, Eugenia has many claims to be considered the most primitive although M Yrria is almost equally old and is certainly closely related to Eugenia. Among the numerous Cretaceous fossils from North America now referred to Eucalyptus there is not a single one that does not exhibit characteristic features of Eugenia or Myrcia, especially the latter, a fact greatly impressed on me in handling a large amount of recent material during my study of the Wilcox forms.

In the Wilcox flora there are six well-marked species of Myrcia and four nearly equally well marked species of Eugenia as well as a single species of Calyptranthes. The latter genus appears also to be represented in recent collections from the Isthmus of Panama. Without pursuing the subject beyond the known facts, confessedly meager, and noting the presence in the Wilcox flora of numerous Combretaceæ and a representative of the great tropical family Melastomacec, largely American in the existing flora, both of which are families closely related morphologically to the Myrtacex, it would seem that the known facts, as well as the law of probabilities, suggest America as the original home of the family. That it reached Europe either by way of Asia or the North Atlantic plateau early in the Upper Cretaceous and became cosmopolitan before the close of the Cretaceous. During the late Tertiary this ancestral stock, which largely coinciderl with the existing subfamily Myrtoidex, was forced to withdraw from temperate North America to the American tropics, where it had originated and to which it has since been so largely confined. The types peculiar to the Australian region represent the relics of the Cretaceous radiation with numerous new types evolved on that continent as Andrews has suggested. This is exactly the

${ }^{45}$ See Deane, H., "Observations on the Tertiary Flora of Australia," Proc. Linn. Soc. N. S. Wales, Vol. '15, 1900, pp. 463-475; Cambage, R. H., "Development and Distribution of the Genus Eucalyptus," Presidential Address, Jour. Proc. Roy'. Soc. N. S. Wales, 19r3.

PROC. AMER. PHIL. SOC., LIII, 2 I4, O, PRINTED JULY I4, I9I4. 
reverse of the hypothesis proposed hy. Deane (op. (it.) but one that accords far better with the facts not only of geologic history, but with those of existing distribution.

As is pointed out in the systematic part of this work all of the Wilcox forms are coastal types closely related to existing American species of similar habitat. About ${ }_{5} 50$ fossil forms have been referred to the Myrtacex, one third at least having been described as species of Euculyptus. It least half of these occur in the Cretaceons of all parts of the world, but particularly throughout the northem hemisphere. They are especially well represented in North America and the possibility that they are ancestral forms of Myrcia or Eugchiu has already heen pointed out. A similar widespread distribution but less specific variation characterizes the Eocene forms that have been referred to Eucalyptus. The Oligocene records are all European and the Niocene records include both Europe and Isia.

The genus Myrtus has about 24 fossil species, all European, the majority heing almost equally divided between the Oligocene and the Miocene. The oldest forms are early Eocene but the form-genus Myrtophyllum Heer has several Upper Cretaceous species in Europe, America and Australia, as well as Tertiary species in Europe. Asia and South America.

The genus Myrcia DC. so well represented in the Wilcox flora has species in the Furopean ()ligocene, four species in the early. Tertiary of Chili and one in the Pliocene of Brazil.

The genus Eugenia, also prominent in the Wilcox flora, has its oldest known species in the Dakota sandstone. It is represented in Europe throughout the Tertiary from the lower Eocene to the Pliocene.

The genus Callistemon R. Brown has been identificd in both the Liper Cretaceons and Tertiary of Enrope and no less than 25.5 species have heen referred to the genus (allistomophyllum Ettingshausen. These include Upper Cretaceous forms in America and Europe, Eocenc forme in Circenland and . Anstralia, and numerous Oligocene and Miocene species in Europe.

Leptospermum. Leptospermitis and Leplospermocarpun havebeen identified from the liper Cretacens and Tertiary of Europe: Tris- 
tania-like fruits have been described as Tristanites by Saporta from the lower Miocene of France: the genus Psidium Linné, with about Ioo modern species in the West Indies and Mexico, is represented in Chili by an early Tertiary species: and finally the genus Metrosideros has been identified in the Atane beds of Greenland and in both the Oligocene and Miocene of Europe.

The family Combretaceæ (Terminaliaceæ) embraces about I6 genera and 285 existing species of shrubs or trees and tropical vines, with simple, entire, coriaceous, persistent, exstipulate, alternate or opposite leaves. The inflorescence is racemose or capitate and the flowers are regular, perfect or polygamous, often apetalous. The stamens are two or three times as numerous as the petals and the one-celled ovary develops into a drupaceous or berry-like indehiscent fruit, often crowned with the accrescent calyx and containing a solitary seed without endosperm.

The existing species are all tropical or subtropical, ranging from $34^{\circ}$ north to $35^{\circ}$ south latitude, and a relative large number are littoral or strand types. The various continental areas have the following peculiar species: America 75, Africa 85, Madagascar 36, Asia 57, Australia 23. About ten or a dozen species are found in more than one area, there being a remarkable identity between the American tropics and those of West Africa, the genera Cacoucia, Conocarpus and Laguncularia having identical species in both regions.

The geologic history of the family is most incomplete, but it is exceedingly prominent in the Wilcox flora where it is represented not only by characteristic leaves but by flowers and fruits. No species are certainly known from horizons as old as the Upper Cretaccous although a species of Temmaliphyllum has been described from the Perucer beds (Cenomanian) of Bohemia and a species of Conocarpites from the Tuscaloosa formation of Alabama. So far as I know there are no authentic occurrences as old as those of the Wilcox. In this flora there are three well-marked species of Combrctum, a genus with about I 30 existing species found in all tropics except Australia and Polynesia. Over thirty of these are endemic in South America and their abundance in the Wilcox as well as the 
ocemrence of a species in the early Tertiary of Chili strongly sugegests that the genus is of American origin. This statement as well as the determination of the $\mathrm{IVilcox}$ species receives confirmation in the rematrably preserved flower from the-e leds described as comberanthitcs. Combrctum has been recorded from the Niocene of Switzerland and Germany, and from the Pliocene of Italy. It occurs in the Claiborne group of the Mississippi embayment and Felix has described petrified wood from the supposed Eocene of the Caucasus which he calls Combretacinium.

The genus Conocarpus Grertner, a member of the tropical mangrove association, has a well marked species in the Wilcox flora which is supposed to be descended from the Conocarpites described from the Tuscaloosa formation in this same general regin. Inother species very close to the modern form of the American tropics occurs in the Claiborne group. Conocarpus fruits have also been described recently from the Aquitanian of Rhenish Prussia.

The genus Laguncularia Grertner, monotypic in the mangrove association of America and the west coast of tropical Africa, is represented by both leaves and fruits in the Wilcox flora. The only other genus of Combretacee with known fossil representation is Terminalia Linné It is a large genus in the existing flora with over one hundred species almost equally divided between America; Asia, Ifrica and In-tralia, sereral of the species being very wirle-ranging littoral types. There are three IVilcox species, based on both leaves and fruit. One of the species makes its appearance in the underly-

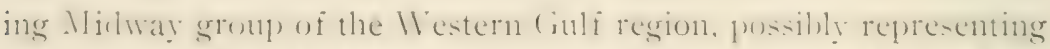
the begimning of its extension morthward along the coats in the embayment region from tropical America.

Five Oligocene species of Terminalia have been described from Europe, the determinations resting on both leaves and fruits, and the occurences ranging from the Samnoisian to the Chattian and geographically from southeastern France to Greece. There are seven well distributed Miocene species in Europe, as well as Pliocene species in both Spain and Italy along the shores of the Pliocene Mediterranean Sea. A supposed Pliocene species is also recorded from liolivia. 
While future discoveries will have to greatly amplify the fossil record before the history of the family in past times can be traced with any degree of surety, the remarkable display of these forms in the Mississippi embayment region, evidently derived from the American tropics, gives a large amount of probability to the theory that the family originated in the American tropics during the Upper Cretaceous.

The genus Trapa Linné, formerly included in the family Onogracere, is now made the type and only genus of the family Hydrocaryaceæ (Trapaceæ, Dumort, I827). There are three existing species, all aquatics, and all confined to the old world except for the naturalization of Trapa natans Linné, in New England and New York. The latter species is found irregularly scattered throughout central and southern Europe, its area of distribution being a contracting one as shown by its occurrence in post-glacial deposits at very many localities beyond its present range in Russia, Finland, Sweden and Denmark. The two other existing species are Trapa bicomis Linné of China and Trapa bispinosa Roxburg of southeastern and southern Asia (said also to occur in Africa).

The genus has an extended geological history. Rosettes supposed to represent the floating leaves (Trapa? microphylla Lesq., and Trapa? cuneata Knowlt.) are widespread in the Rocky Mountain province in beds of late Cretaceous and early Tertiary age. The oldest recognizable fruits are a large bi-cornute form from the Eocene of Canada and Alaska and Trapa wilcoxensis Berry found in the Wilcox flora. An Oligocene species (Trapa Credneri) Schenk has been described from Saxony, and no less than seven species have been described from the Miocene-two occurring in Idaho (Payette formation), one in Japan and the balance in Europe, where two species continue into the Pliocene. A species from the late Pliocene of America is found in southern Alabama. The existing Trapa natans has been recorded from the preglacial beds of England and Saxony and from very many interglacial and postglacial deposits in Portugal, Italy, Netherlands, Germany, Sweden, Russia and Denmark, Gunnar Andersson in a recent paper (I9IO) mentioning I8 localities in West Prussia, 6 in Denmark, I7 in Sweden and 29 in Finland. 
The family Melastomacex is a relatively large one with about I50 genera and over three thousand existing species. It is almost strictly tropical although some members range southwarl to $40^{\circ}$ south latitude. It is a typically. American family, seren of the fifteen tribes into which the family is divided being confined to tropical America, and about 2,500 of the existing species being also endemic in this region. While the geologic history of this rast assemblage of forms is practically unknown, there is no evidence to disprove the theory that it, like the allied families Combretacex and Myrtacer, had its origin in that most prolific region-the American tropics.

The few fossil forms that have been found, including leaves, flowers and calices, have been referred to the form-genus. Mclastomites first proposed by Lunger. A doubtfully determined species, which probably belongs to the Lauracere, had been recorded from the Upper Cretaceous of Westphalia. The only known Eocene species is the well-marked form present in the IVilcox flora. Four Oligocene species have been described from Bohemia, Styria and Egypt; four Miocene species from Switzerland, Prussia and Croatia; and a Pliocene species from Italy.

The order Lmbellales (Lmbellifore of Engler) includes but three families - the Araliacex, Umbellifere and Cornacex, together with upwards of 3,000 existing species of which more than twothirds belong to the Lmbellifere. The three families are closely related and stand somewhat apart from the rest of the choripetalous orilers. While undoubtedly there has been great specific variation in very molern times especially among the herbaceous forms of Lmbelliferit, some members of the alliance go back as far as undoubted dicotyledons have been found, and this fact is one of the strongest arguments for considering its relationships to the Gamopetalie to be less close than some botanists have sugrgested, a suggestion based primarily on a consideration of the floral structures apart from the morplobogical features of the whole plants As regards thral evolution the Cmbellales clearly mark its highest expression among the Choripetalit and parallel the Camopetalie. The flowers are epigynous, with cyclic stamens, reduced carpels, and often reduced sepals. The Iraliacea and Cornace are both positively and the Lmbellifere doubtfully represented in the Wilcox flora. 
The family Araliacex contains about 52 genera and 500 existing species, chiefly inhabitants of the tropics, the notable exceptions to this statement being in North America and eastern Asia. The modern center of development is in the Asia-Australia region, no less than 33 genera being confined to Asia, Malaysia, Australia or Polynesia. Africa has three peculiar genera with about 30 species; America has five peculiar genera with about Ioo species. The genus Scheffera is cosmopolitan. Hedera and Polycias occur in Eurasia and Africa. Two genera are common to Asia and America and Aralia adds Australia to a similar distribution. Pseudotena $x$ with about six species is peculiar to western South America and New Zealand.

The fossil record is not nearly as complete as it should be to afford a secure basis for generalizations. A number of genera are found, however, in the oldest deposits in which undoubted dicotyledons are known. The largest genus is Aralia, commonly used by paleobotanists as a form-genus for generically unidentified species of Araliacex, rather than for forms falling within a strict modern definition of Aralia. No less than fifty species of Aralia have been described from the Cretaceous. Two of these come from horizons as old as the Albian of Portugal. In beds of similar age in eastern America (Maryland and Virginia) there are two well-marked species referred to Araliaphyllum and clearly ancestral to the numerous species of Aralia so common in the Upper Cretaceous of the latter region. Very similar, in some cases identical, forms are found in the Cretaceous on both sides of the Atlantic. There are fifteen species in the Perucer beds (Cenomanian) of Bohemia and Noravia and a like number in the Dakota sandstone of the western United States, while along the east coast there are nine species in the Raritan formation, eight in the Magothy formation, and one each in the Black Creek formation of North Carolina, the Eutaw formation of Georgia, the Tuscaloosa formation of Alabama and the IVoodbine sand of Texas. In Greenland there are two species in the Atane beds and a third in those of Patoot. In the younger Cretaceous there are two species in Tohemia, two in Westplialia and one in Colorado. Australia has a species and ten supposed varieties of Aralia in the Upper 
Cretaceous beds of that country. In addition to the foregoing display, the allied genus Araliopsis (Berry I9I I) has a number of wellmarked species in the Raritan. Magothy and l)akota formations. so that it must be conceded that the araliaceous stock was well differentiated and cosmopolitan before the close of the Cretaceons. ${ }^{46}$

There are over a score of Eocene species of Aralia, they being especially common in the Fort Union of the western United States, the Paleocene of Belgium, and the Eocene of Australia. The three Wilcox species are not common-two of them are common Fort Union species and the third was described originally from western Greenland. In addition there are species in the Denver formation, the Green River formation, in Oregon, New Zealand, Italy, and the south of England.

There are upwards of twenty Oligocene species, especially in the Samnoisian of southeastern France from which $1_{4}$ species have been described. All of the other Oligocene records are also European.

There are also about twenty Miocene species distributed over North America, Europe and Asia. Some of the California species, c. g., Aralia Whitney'i, are clearly ancestral to existing Asiatic eastcoast forms. A fruit (Araliacarpum) is described from the Miocene of Prussia. There are in addition between 15 and 20 fossil species of Aralia more or less doubtfully connected with other genera of the family, $c$. y. there is a species of Arthrophyllum doubt fully irlentificel from the upper Oligocene of France; a species of Cephalopana.t (?) is recorded from the lower Miocene of France: several forms of Sciadophyllum (?) occur in Greenland, Bollemia and France; and Paratropia (?) is recorded from the Paleocene, Oligocene and Miocene of France and the Miocene of Bohemia.

There are two species of Orcopana.r in the Wilcox flora, one of them exceedingly well marked and clearly referable to the section Digitate of Oropunar. The latter gemus has about eighty existing species with simple, lobate and digitate leafed sections confined to tropical America but present in the Paleocene, Tongrian and Aquitanian of France. The modern Asiatic genus Acanthopana.r Decaisne and Planchon has (Oligoeene species in France and fiemany, and a Miocene species in Japan.

to See Berry, "Aralia in American Paleobotany," Bot. Gaz, Vol. 36, 1903, pp. $421-428$. 
The genus Pana.r Linné with about six existing species in Asia and North America has furnished a number of fossil forms based on numerous characteristic fruits as well as leaves. It is representec from Greenland to Alabama along the west coast of the Atlantic and in the Perucer beds of Bohemia (Araliphyllum). It has five species in the Oligocene of Europe and six Miocene species in Europe and Colorado. The genus Cussonia Thunberg with about 25 African species in the existing flora is doubtfully recorded from the Albian of Portugal. It is present in the Perucer beds of Bohemia (Cussoniphyllum) and in the Oligocene of France and Greece.

The genus Hedera Linné with only three existing species of Europe, Asia and Africa has numerous and well-defined fossil forms. ${ }^{47}$ No less than fifteen have been described from the Upper Cretaceous of both America and Europe. There are about seven Eocene species in Greenland, Alaska, the Fort Union of the western United States, and in the Paleocene of Belgium and France. The genus remains common during the Tertiary in Europe and is present in - Imerica as late as the Lper. Miocene lake of Florissant, Colorado. The anecestor of the existing Hedera heli. Linné occurs in the Pliocene of central France and the modern form itself is found in the Pleistocene of England, France and Italy. A species of Polyacias occurs in the Pleistocene of Java associated with Pithecanthropus erectus.

The family Umbelliferæ with I70 genera and upwards of two thousand existing species is distinctly an extratropical family with numerous boreal forms. The majority are herbaceous and of relatively modern origin. It is very sparingly and cloubtfully represented in the fossil state and the only Wilcox form that suggests such an affinity is the fruit described as Carpolithus prangosoides which greatly resembles those of the existing genus Prangos Lindley.

The third family of the Umbellales, the Cornacex, is a relatively small one, with only sixteen genera and about roo existing species, mostly of the temperate zone. The fossil forms are confined to the two genera Cormus and Nyssa. Cormus has about 40 existing species of herbs and small trees mostly confined to the north temperate zone

47 The forms from the Potomac group of Maryland and Virginia described by Fontaine as species of Hedercphyllum are entirely worthless. 
in Lumasia and North America but represented in Mexico, and with a single species in Peru. Over fifty fossil species have been described. There are at least twelve in the [pper Cretaceous, all confined to North America and ranging from Greenland to Alabama. There are about a dozen Eocene species in America, Europe, and the Arctic, one of these is sparingly represented in the Wilcox flora. Oligocene records are few in number but over 25 Miocene species have been described, the genus being particularly abundant at this time throughout central Europe but also represented in both North America and Asia. About five Pliocene species are recorded from Spain, France, Italy and Japan and the genus has afforded Pleistocene material in New Jersey, Holland, England, etc.

The genus Ny'ssa Linné (including also Nyssidium Heer and Nysites Geyler and Kink.) comprises about seven existing species ranging from shrubs to large trees, natives of southeastern North America and eastern and central Asia. It has furnished over fifty fossil forms, the majority being based on the characteristic costate stones. The oldest known forms are from near the base of the Uper Cretaceous (Dakota, Tuscaloosa) of North America. By Eocene time I'jsa had reached Alaska, Greenland and Europe. There are two characteristic species in the Wilcox, both based on stones, and a third occurs in the overlying deposits of the Claiborne group. In the lignite deposit of Brandon, Vermont, of uncertain but probably carly Tertiary age, no less than eighteen so-called species of stones have been described, and while doubtless the specific differentiation is overefined, it emplasizes the abundance of 1 lissa in New England at that time. Nyssa is abundant in the European Cligocene and there are Miocene species in New Jersey, Virginia, Furope, and Asia and a l'lucene species occurs in Alabama. Some of the modern species are common in the Pleistocene of this country. from New Jersey southward.

While much remains to be learned regarding the history of the Cornaceat it reems clear that the two genera (ornus and lysis which have yelded fosil iorms are both types that appear to have originated in North America during the Cretaceous.

Vis fanily of the Choripetale has succected in maintaining a 
world-wide distribution as have several families of Monocotyledone and Gamopetalie. No distinctly boreal group has been developed as among the Gamopetalie (Ericales). Certain great families characterize the north temperate region and these are all herbaceous forms believed to be of relatively recent origin, e. g., Polygonaceæ, Caryophyllacex, Crucifere, Saxifragacex, Onagracex and Limbelliferx. While aquatic forms are common this habit does not characterize whole families as among the Monocotyledonæ. The Choripetalæ predominate in the American tropics and many of the families present in the Wilcox flora have been shown to have probably originated in that region.

The second grand division of the Dicotyledonx, the Gamopetale (Sympetalie), constitute a rather well-defined group, presumably derived from the Choripetalæ, and characterized by a complete cyclic arrangement of the floral parts, a usually gamopetalous corolla, ovules with a small nucellus and usually a single integument. It contains nine or ten orders and upwards of 50,000 existing species. The majority of the orders appear to be more compact and natural groups than the corresponding alliances among the Choripetalie. The Ericales, Primulales and Ebenales are pentacyclic and isocarpous, while the Gentianales, Polemoniales, Personales, Plantaginales, Rubiales, Talerianales and Campanales are tetracyclic and anisocarpic, the last three orders being epigynous.

The alliance predominates in herbaceous forms and several of the families are distinctly boreal. While the Compositæ, Labiatre and Plantaginacex are of world-wide distribution there are no notable continental pairings such as is usually the result of an cxtended geologic history. These and many other facts suggest that the (iamopetalie as a whole, especially the more evolved, herbaccous. extratropical families, are of relatively modern origin whose major specific differentiation was concomitant with the occupation of the temperate zones after the retreat of the Pleistocene ice-sheets.

From the viewpoint of floral structures the so-called Compositæ are clearly the culmination of the evolution of floral structures. This is shown not only by their gamopetaly, epigyny, connivent anthers, and the formation of seedlike fruits with a pappus, but by the complex flowerhead, the prevalence of diclinism, the climoryhism of the 
corollas and other special features. This theorem is corroborated by the in general modernness of the alliance.

Six of the Gamopetalous orders are represented in the IVilcox Hora. The first of these, the I'rimulales, in its fullest development in existing floras inclules the three families Mrrsinacese. Primulaces and l'lumbaginacee'. They are structurally much alike with a single cycle of stamens opposite the petals, and a unilocular ovary with a free central placenta. This community of floral organization can only be attributed to convergence and not to filiation since the Myrsinacer are old forms which in modern floras are predominantly tropical and American while the Primulacee are chicfly north temperate and boreal herbs of relatively recent evolution: and the Plumbaginaceæe are very modern halophytic herbs and undershrubs of salt beaches and steppes, the majority being found in the Mediterranean and Caspian regions.

The Myrsinacex, the only family represented in the IVilcox flora, is characterized hy alternate, simple, coriaceons, punctate, exstipulate leaves: perfect, regular flowers : and single seerled drupacents fruits.

The family contains about thirty genera and 530 species of shrubs or trees, largely tropical and predominantly American. Thus eleven genera containing upward of 200 species are peculiar to America while there are only four genera with less than a dozen species peculiar to Asia, and three genera with about roo species peculiar to Africa.

The genus Myrsine Linné is found on all the continents except Europe and in Polynesia. Its distribution is extratropical in the African region. Euardisia Pax is found in all tropics. Maesa Forskal is found in all oriental tropical comntries as is also the mometypic

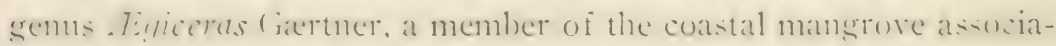
tion. The genus Cybianthus Martius, largely South American, has species in the Philippines and in New Grenada. There is little that is significant in the recent distribution of the family and the fossil record is very incomplete.

Over seventy-five fossil forms have been referred to Myrsine. The olclest are the seven or eight forms recorded from the Upper

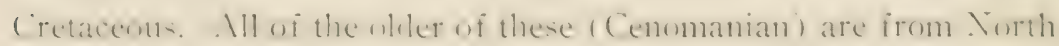
America and only one from the Turonian of Bohemia occurs in the 
European Upper Cretaceous. The American forms are not varied specifically but are widle ranging and common, extending from the Atane beds of Greenland along the Atlantic coast to the Tuscaloosa formation of western Alabama as well as in the Dakota sandstone of the western interior.

The recorded Eocene species of Myrsine number seven or eight and include an Australian form, one in the early Eocene of Alum Bay, three in the upper Eocene of France, and two in western Alaska. Myrsine is exceedingly varied and abundant during the Oligocene throughout southern Europe, over thirty species laving been described, of which eleven occur in the basal Oligocene of southeastern France (Sannoisian). There are upwards of thirty Miocene species throughout Europe, one in Colorado being the only known American occurrence. Several species linger in the Pliocene of southern Europe in France and Italy and one species is present in the Pliocene of Brazil. In addition to the forms referred to Myrsine several forms from the European Tertiary have been referred to the form-genus Myrsinites. Ettingshausen recorded a species of Pleiomerites from the Miocene of Bohemia; and the genus Maesa Forskal, which has about 40 modern species in Asia, Africa, Australia and Polynesia, is represented in the Oligocene of Transylvania and Egypt and in the Miocene of Styria.

The genus Ardisia Swartz (including Ardisiophyllum Geyler) has furnished about a dozen fossil species, the oldest of which, a very doubtfully determined form, comes from the Turonian of Bohemia. There is an Eocene or Oligocene species in Chili, three Oligocene species in Bohemia and one in Transylvania. There are four Niocene species in France, Bohemia and Styria; and Pliocene species in Italy and Borneo.

The genus Icacorea Aublet is the only member of the Myrsinacex found in the Wilcox flora. The genus has numerous existing species confined to South America. The fossil record is meager but includes two or three species of the European Oligocene. The Wilcox species is thus considerably older than any European occurrence. It represents a form which is very close to the modern Icacorea paniculata Sudworth, a shrub or slender tree of the Filorida keys, Baha- 
mas, Cuba and the east coast of southern Mexico. In addition to the forgoing records at least four kinds of flowers have been described from the Faltic amber (Samoisian). These are Berendia (ineplert 12 species). Myrsinopsis Conwenz, and Scnuclia Gappert.

While the geologic history of the family is thus so incomplete it is not without significance in this case as in the case of so many families previonsly discused, that a preclominantly. Imerican family in the existing flora las its oldest known fossil occurrences in the basal Upper Cretaceous of North America.

The order Fbenales includes the families Sapotacex. Fhenacex. Styracacese and Symplocacex, together with upward of one thousand existing species, the larger families being the Sapotacea and Elenaces, both of which are represented in the IVilcox flora, white the other two families are sparingly representer in the European Tertiary. There is considerable range in floral structures from indefinitenes in the number of stamens and carpels and polypetaly, to $a+$ to $\&$ cyclic arrangement, which leads floral morphologists to consider the order as among the most primitive of the Gamopetalie.

The family Sapotacex comprises trees or shrubs with a milky juice and with alternate, simple, entire, mostly coriaceons, petiolate. exstipulate leaves. It contains about thirty-two genera and nearly four hundred existing species of all tropical conntrics. Mhout hali of the existing species are American. There are eleven genera confined to America, seven to Africa, three to Australia, two to New Caledonia, two to Asia and Malaysia, two to Malaysia and one to Asia. The three large genera, Siderorylon, Chrysopliyllum and Mimusops, are represented in all tropical comntries. There are four genera and twelve species represented in the Wilcox flora. The largest of these genera is Bumclia Swartz with six well-marked IVilcox species. Bumclia with about a score of species is confined to Imerica in the existing flora, ranging from the sunthern United States through the West Indies and Central America to Brazil. It has numerons fossil species, the olkest coming from the lpper (retacerus (Dakota sandstone) of the western interior. In addition to the six Wilcox species, which are protolypes of still existing forme. there are two Eocene species (Ypresian) in southern England. 
There are about a dozen Oligocene species, ten of which are widespread in Europe, one is found in the Apalachicola group of western Florida and two forms, representing both leaves and fruit, are found in the Vicksburg group of Louisiana and Texas. There are seren or eight Miocene species widespread in Europe and one is recorded from the late Miocene of Colorado.

The genus Chrysophyllum Linné with about sixty existing species found in all tropical countries, but the majority American, has a supposed species in the Upper Cretaceous of Saxony (Niederschœna); a well marked species in the Wilcox flora; three Oligocene and six Miocene species in Europe.

The genus Mimusops Linné with about 40 existing species in all tropics has three well-marked Wilcox species and a fourth in the overlying Claiborne deposits. To it has been referred a species from the Lpper Cretaceous of Saxony (Niederschœna) and it is undoubtedly represented in the Upper Cretaceous of the embayment region as well as elsewhere by the leaves that have been referred to the form-genus Sapotacites.

The genus Sideroxylon Linné, with about eighty existing species in the oriental tropics and about fifteen in the American tropics, has two species in the Wilcox flora which are the oldest thus far discovered. To this genus have been referred four Oligocene and one or two Miocene species from Europe.

Isonandra Wright a small modern genus of the Malayan region is represented in the Tertiary of Borneo by Isonandrophyllum Geyler; the genus Achras Linné (Sapota Plumier), now monotypic in the Nest Indies, has three species in the European Miocene; Labatia Swartz, with six existing species in the American tropics, has been doubtfully determined in the Miocene of Prussia and Italy; and Felix has described two forms of petrified wood which he refers to this family under the name Sapotoxylon, one species from Germany and the other from an unknown locality and horizon.

A large number of fossil forms of Sapotacex have been referred to the form-genus Sapotacitcs proposed by Ettingshausen (also Sapotoplyllum). There are at least ten Upper Cretaceous forms wiclespread in North America and represented in Europe in the l'erucer 
beds of liohemia and the Credneria stage of southern Saxony (Cenomanian). Three of these Upper Cretaceous forms are from the Tuscalensa formation of Mabama and undoubtedly represent the ancestors of some of the Wilcox forms. There are about ten recorled species of Sapotacites in the Eocene of Australia. France and southern England. There are about a score of species in both the Oligocene and Miocene, most of which are European. There is, however, an uncescribed species in the Ipalachicola group of western Florida. In the Pliocene there are species in southern Europe and on the island of Java.

Notwithstanding the incompleteness of the record it is obvious that the family heame well differentiated during the Cpuer Cretaceous and while it would not be safe to assign its place of origin to the Imerican region, it is probahle that at least several of the genera. such as Bumelia for example, originated in this region.

The family Elonacea inclutes about eight genera and upwarls of three hundred existing shrubs and trees, of which over half are referred to the genus Diospyros Linné. The family is mainly tropical as are most of the species of Diospyros, but the latter is represented in the north temperate zone in eastern North America, eastern Asia, and the Mediterranean region. The three modern monotypic genera, Tetraclis, Brachynema and Rhapidanthe are confined respectively to Madagascar, Brazil and West Africa and none have been found fossil. The genus Royena is mostly South African; Euclea is entirely confined to Africa: Maba, a large gentus, ranges from Africa eastward to Polynesia; and Macrightia is common to tropical Africa and America.

Diospyros with about ISo existing species is cosmopolitan. Between 90 and 100 fossil forms have been described. In that grand displat of dicot!ledhnous genera which during the micl-cretalecons re-

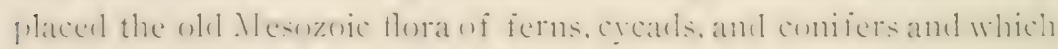

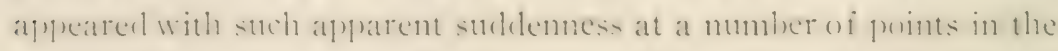
northern hemisphere, we find ummistakable evidence of the abundance and wide distribution of species of Diospyros. No less than seventeen different forms have been described from the rocks of this age, and the localities where they have been found are scattered 
from Australia to Bohemia, Greenland, and Vancouver Island. A large majority of these species are American, and they seem to have been especially at home along the Cretaceous coast of the Atlantic and along the borler of the Mediterranean -ea which extended northwestward from the Gulf of Mexico over much of our present Great Plains area. One of these species, well named Diospyros primcia by Professor Heer in I866, is especially widespread and abundant, being found not only in Iowa, Kansas, and Nebraska in the west but also from Texas eastward through Alahama and northward in South Carolina, North Carolina, Maryland, New Jersey, Long Island and Greenland, or from latitude $33^{\circ}$ to latitude $7 \mathrm{I}^{\circ}$ north. That these early persimmons were not very different from those of today is shown by their similar foliage. This resemblance is also shown by the fossilized remains of the calices of various species. One of these calices from another early Cretaceous species, recently described by the writer, is Diospyros vera, found in what is known in the Potomac River valley as the Raritan formation. Apparently the habit of accrescence had not been fully formed but the calyx was persistent then as now and entirely like a modern calyx in appearance. It was four-parted as it usually is in existing persimmons, but other fossil forms had a five-parted calyx like a good many present day tropical species.

In the Eocene epoch, which succeeded the Cretaceous, the records of the fossil occurrences of Diospyros show that it was truly cosmopolitan. These records include about 20 species in Siberia, Alaska and Greenland on the north; Canada, various localities in Europe, as well as Colorado, Montana, Wyoming, Nevada, Oregon. Washington, and other western states. Lnfortunately, we have no Eocene or later Tertiary records along the Atlanic coast of North - Inerica outsile the embanment region since the preserved deposits are all of marine origin and contain no fossil plants. There is little conit. however, that Irospyros continued to be an abundant element in the aborescence flora of this area.

There are two well-marked species of Diospyros in the Wilcox flora, one of which continnes in this region through the Claiborne. IROC. AMER. PHIL. SOC., LIII. 2 I 4, I', PRINTED JULY I4, I9I4. 
A large calyx is present in ilue Claiborne or Vickshurg of southuestern Texas.

There are ahout 2 Oligwene species, Dioshyos being e-pecially common throughout southern Europe. There is an American species of this age in the Apalachicola group of westem Florida. The luxuriant forests of the Mivene have furnished abut twenty species of Diospyos, the known distribution at this time inclukles European localities from Spain to Hungary and American records in Oregon, California, Yellowstone Park and Colorado. There are seven Pliocene species in southern Europe and in Java.

The allied genus Royena Linné has furnished splendidly preserved fruits from the oasi- Chargeh in Egypt (Lpper Cretaceous) as well as four Oligocene and two Miocene species in Europe. It seems never to have been cosmopolitan like Diospyros, since it has never been recognized in the western hemisphere. The fossil history of the genus Euclea Linné was evidently similar to that of Roy$c n a, i . e$., it makes its appearance in the basal Oligocene of Europe where it is represented throughout the ()ligocene and Miocene, hecoming confined to Africa in Plio-Pleistocene times.

The genus Macreightia. DC. has nine or ten existing species, one occurring in tropical. Africa and the balance being - Inerican. Marrelylitia is represented by both leaves and flowers in iossil horas and it has been a favorite receptacle for tripartite calices, not always of astured botanical identity. The oldest form is one in the German ()ligocene and there are five or six species in the European Miocene. It has not been definitely recognized in North Imerica, althongh some of the IVileos material is not unlike some European material referred to . Macriglitiu. Felix has recognized wood of this family (Ebeno.rylon) in the Oligocene of the Island of Antigua.

The order Gentianales (Contortæe of Engler) includes six families with hetween four and five thou-and existing -pecies, the largest family heing the Lecplatace with upwards uf two thousand species. The families are complexly interrelated among themselves and with the next two orders, about the only constant characters leing the opposite leaves and the generally twisted corolla in a-tivation. The Asclepiadacex, not found in the Wilcox, shares with the 
Apocynacex in the development of a latex-system and in other specializations, and the elaborate contrivances for entomophily in the former family reach a degree of complexity almost comparable with that of the Orchidacex. The Loganiacex, also not represented in the Wilcox flora, are lianas characteristic of South America and Asia and regarded by Engler as relatively primitive and possibly the ancestral stock of the Gentianales and Rubiales. The order as a whole is numerically massed in the tropics by reason of the many tropical genera of the two largest families-the Asclepiadacex and Apocynaceæ, which together contain three fourths of the existing species of the order.

The family Oleacex, sometimes considered as an order, the Oleales, contains $2 \mathrm{I}$ genera and about 400 existing species. There are three small genera peculiar to Asia and four peculiar to America, the remaining fourteen genera being found in more than one contitinental area. The three largest genera Fraximus (40), Mayepea (50) and Jasminum ( I60) are all cosmopolitan. Eight of the twenty-one genera have been found fossil and it is evident that the family has an extended history, although there are no known Cretaceous records worthy of credence. Nor is the record well enough known to warrant generalizations. It is obvious from the early Eocene occurrence of leaves of Fraxinus associated with characteristic fruits, that the family must have been evolved before the close of the Upper Cretaceous but none of the genera have any well-marked or abundant known representation until Tertiary times.

The gents Frarimus Linné has two species in the Wilcox flora, a characteristic samara, and foliage identical with that describer by Heer from western Greenland as Fraximus Jolnstrupi. The latter furnishes an interesting instance of the extended distribution of members of the Eocene flora, at the same time illustrating the northward radiation of floras during the Eocene. Upward of ten additional Eocene species are known all of which are American and ranging from Tennessee to Alaska and Greenland. The Oligocene marks the appearance of the genus in Europe from which time to the present the genus has been represented throughout the warmer parts of the north temperate zone, at least four of the existing species making their appearance in the Pleistocene. 
The second genus represented in the 11 ilcox flora is Osmanthus Lour. It has about ten existing species of eastern North America, eastern Asia and Polynesia. The Wilcox species is exceedingly close to Osmanthus americanus $\mathrm{B}$ and $\mathrm{H}$ of the Atlantic and Gulf coasts from North Carolina southward. A second fossil species is found in the Niocene of Florissant, Colorado.

The old world genus Phillyrea Linné is found fossil in Europe; the genus. Votelea Vent., which has six existing - Instralian species and an isolated remnant of its former clistribution in $\backslash$ adeira and the Canary Islands, is represented in the Eocene, ()ligocene and Miocene of Europe: the genus Olea Linné with orer thirty existing species ahout erpully divided between Africa, Asia, and Australia and Polynesia, has about twenty fossil forms (including Oliophyllum Conwenz and Olecaram Menzel) in Europe where they range in age from the basal Eocene through the Oligocene, Miocune and Pliocene to the Pleistocene. The genus is not known in American fossil floras but there is a supposed species in the early Tertiary of Australia.

The genus Ligustrum Linné with about 35 existing species in southeastern Asia and the East Indies has three species in the ()ligocene and Wiocene of Europe. ${ }^{4}$ Saporta has described representatives of the genus Syringa Linne from the Sannoisian of southeastern France, the occurrence of the latter genus being based on floral remains.

The family Apocynaceæ comprises I33 genera and between ten and eleven hundred existing species of perennial herbs, vines, shrubs and trees, mostly with a milky acrid juice and simple exstipulate leaves. The fruit is usually a pair of follicles or drupes and the secels are often comatose. The family is amost expually divided into two subfamilies, the Plumerodice having os genera and about 550 species and the Echituidea having 65 senera and about 500 species. The senera L'lumeria Linné with abunt fo species, and Raniolfia Limne with aluut t5 species, are cosmopolitan, mostly tropical: and 24 sencra with absut 300 species nceur in more than one continental area. America with 36 peculiar genera containing about 325 species

is A species of Ligustrum recorded by Hollick from the Upper Cretaceous of Long Island is probably a Pisonia. 
heads the list, followed by Africa with 28 peculiar genera containing about I3O species, and Asia with 20 peculiar genera containing about 75 species. Australia has few endemic genera or species, but numerous genera range from Asia or Africa to the Australian region and several genera are peculiar to Malaysia and to Polynesia. In the present state of our knowledge the distribution does not furnish material for generalization.

The fossil record, although including the representatives of at least a dozen genera, is too incomplete to shed much light on the history of the family or its existing distribution. The largest fossil genus is the form genus Apocynophyllum proposed by Heer and embracing fossil forms resembling Theretia, Cerbera, Apocynum and other existing genera of the family. Five species are recorded from the Lpper Cretaceous, coming from the Dakota sandstone, Australia, Westphalia and Saxony. There are over a score of Eocene species widely distributed. There are five species in the Wilcox flora some of which are exceedingly well marked and common. There are also five species in the Y presian of southern England. Other Eocene records include Greenland, Australia, New Zealand and Chili. The score or more of known Oligocene species are confined to European localities. The Miocene species number about 25, all confined to Europe except a form recorded from Italy.

Fossil forms have been sparingly referred to the following genera: Allamanda, Hamadictyon and Thevetia have been recognized by Engelhardt in the early Tertiary of Chili: Alyria, Alstonia, Cerbera and Taberncmontana have been recognized in the European Tertiary by various students: the genus Neritinium Unger has four or five species in the European Miocene: the genus Plumeria has four Miocene species in Europe and a Pliocene species in Brazil. The genus Echitonium Unger has over a dozen fossil species. There are five in the Eocene including a well marked form in the Wilcox flora; two in the Oligocene and five in the Miocene of Europe.

The genus Nerium Linné has only three or four existing species of shrubs or trees in the warmer parts of Eurasia. However the commonly cultivated I'crimm olcander Linné of the Levant grows to a relatively large size and is extensively naturalized in Florida and the West Indies. It is used for hedges in Bermuda. Saporta re- 
corked an Lper Lretaceons species, Lerium Rïhlii, from the Campanian of Wistphalia hut this is almost certainly a member of the Myrtacex and not a Nerium. Undoubted species do occur in the Encenc of Enrope, incluling the remains of a characteristic hower from the Taris basin. There are several ()ligocene and Miocene species in Europe and the existing Nerium oleander or its immediate ancestor occurs in the Pliocene of southern Europe in France and

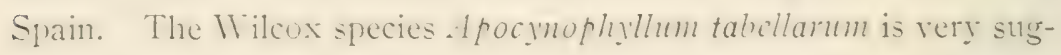
gestive of Ncrimm but the genus is not certainly known in the western hemisphere.

It may be noted that with the exception of the not certainly irlentifierl species of I pocymophyllum the family is not representer in the abundant known Upper Cretaceous floras of the world, which might mean that it originated somewhere in the southern hemi-phere.

The order Polemoniales or Tubiflorit ${ }^{49}$ enntains the four families Convolvulacee, I'olemoniacere. Iy drophyllacese and Borraginacer. The first three are characteristically. American, the Convolvulacee being chielly tropical, while the largest family, the Porraginacer, is typically developed in the north temperate zone.

The family Borraginacex, the only one of the order known in the Wilcox fora, contains about 85 genera and $r$, foo existing species of mostly widely distributed north temperate herbs and shrubs, or trees in tropical countries, characterized by alternate, exstipulate. mostly entire leaves. The known fossil forms are few in number and of slight significance and comprise for the most part Tertiary remains described as species of Borraginites and Heliotropites. The family is represented in the Wilcox by two species of Cordia, a genus containing about 2.30 existing species of shrubs and trees of the warmer regions of both hemispheres, especially the western. There is a species in the Lpper Cretaceons of the Misssissippi embayment area (Tuscaloosa formation) and a Miocene species in Europe. Farly Tertiary forms are recorded from Chili by Engellardt and from Tasmania ly. Ettingshansen. The slight evidence available indicates that the gents originater in the American tropics and that the hulk of the family is of late Tertiary origin.

19 Not the Tubiflore of Engler which includes the orders Polemoniales and Personales, here regarded as distinct. 
The order Personales or Labiatifloræ includes sixteen families distinguished from the Polemoniales by the zygomorphism of the flowers. The specific differentiation is great and the lines of descent are confusing. The largest families are the Labiatæ with over 3,000 existing species, the Scrophulariacere with about 2,500, the Acanthacer with about 2,000, and the Solanacer with about I,800. Two of the sixteen families, the Verbenacex and Solanacex, are represented in the Wilcox flora.

The family Verbenaceæ includes about 73 genera and 1,300 existing species of widely distributed herbs, shrubs, or in tropical countries trees. The family is largely tropical or subtropical and is notably represented in the South American region. The fossil record is most incomplete. The largely old world genus Clerodendron Linné is unnistakably present in both the Eocene and Oligocene of Europe, and Ettingshausen has referred, somewhat doubtfully determined forms from the European Niocene to the American genus Petre Linné and to the cosmopolitan genus Vitex Linné. The genus Citharexylon Linné has about twenty existing species ranging from the Florida keys and lower California through the American tropics to Bolivia and Brazil. A single species found in the middle and upper Wilcox is extremely close to the existing Cithare.lylon villosum Jacquin, a small coastal tree of the Florida keys, Bahamas and Antilles. With the exception of one or two doubtfully determined forms in the Miocene of southeastern Europe it is the only known fossil form.

The genus Avicennia Linné sometimes made the type of a distinct family, the Aricenniaceæ or Black-mangrove family, includes from three to thirty existing species according to the varying interpretation of different students. They are found on all tropical tidal shores. Two species have been recognized in the Wilcox flora, one based on leaves and the second on a not conclusively identified capsule.

The family Solanacere includes about seventy genera and about I600 existing species, widely distributed and largely tropical, but extending into the temperate zone, notably in the western hemisphere. They comprise herbs, shrubs, vines, or in tropical countries often trees, with opposite, stipulate, toothed, lobed or dissected leaves. 
Their fossil history is almost entirely mknown. The single Wilcos representative of the fanily is a flower described as Solanites, a genus founded on the somewhat younger remains of a sinilar flower found in the Sannoisian of France, and comparable with the existing Sonth American genus Saracha Ruiz \& Paron, as well as with Ir ithcringia, Solanum, etc.

The last order of Gamopetalie positively recognized in the IVilcox flora is the Rubiales which inclutes over 5,000 existing species segregated into five families, over four fifths being referred to the family. Rubiacex-the only one represented in the IVilcox.

The Rubiacex includes about 355 genera and over 4,500 existing species of herbs, shrubs and trees: with simple, opposite or verticillate, mostly stipulate, leaves. They are widely distributed and largely tropical. While the Wilcox representation is confined to a single species each of Erostema, Psychotria and Gucttarda, great interest must attach to the fossil record of so highly organized a family which is my justification for introducing the following brief sletch of our knowledge of it.

No less than twenty-five genera have been recognized in the fossil state. With the exception of the very doubtful determination of a species referred to Rubicephllhum from the Turonian of Bohemia and doubtless representing a species of Ericacex, the family is unknown in the Upper Cretaceous. It is however represented in the early Eocene both in America and Europe. The Vilcox forms represent a species of E.rostcma Rich., close to the existing Erostema caribacum R. \&. S. which ranges from the Floricla keys to Central America. The genus comprises about twenty existing species of shrub: and small trees confined to the tropics and subtropics of Amcrica. The second Wilcox species is referred to Gucttarda Endlicher, a genut: of about fifty species mostly confined to the American tropics but inclucling one or two comopolitan tropical maritine species. The Wilcox form is very close to the existing Gucttarda clliptica Swartz, a small tree of the Florida keys, Bahamas and West Intlies. The third Wilerex species is I'sychotria arandifolia fleseribed originally by Engelharelt from the early Tertiary of Chili. The genus Psychotriu Linné comprises alout $35^{\circ}$ existing species of shrubs and small trees in tropical America. Asia and the Fast Inties, two thirds 
of its species being American. The fossil form is compared with Psychotria grandis Swartz of the American tropics.

The genus Coussarea Aublet with about 40 existing species in the Brazilian region has been identified by Engelhardt from the carly Tertiary of Chili. The genus Hoffmannia Swartz with about a scure of existing American herbs or shrubs, mostly confined to Central America, has a fossil species in the early Tertiary of Chili. Likewise the genera Sabicca Aublet and Gonatteria Martius each have a single species in the Tertiary of Chili.

The Baltic amber (Sannoisian) has yielded a flower referred to Sendelia and a leafy twig referred to Enantioblastos. The genus Galium, comprising over 250 widely distributed existing herbaceous forms, has been doubtfully identified from the Eocene of Greenland. Its fruits are also not uncommon in Pleistocene deposits. The genus Randia Houst., embracing about one hundred existing species of shrubs or trees in all tropics, is identified by a fruit in the Aquitanian of Rhenish Prussia.

The genus Rubiacites so named by Webber from its resemblance to the existing forms of Rubia Linné has furnished three species of leaves and flowers in the Aquitanian of Prussia and Switzerland. The genus Gardcnia Ellis, containing about sixty species of shrubs or rarely trees of the eastern hemisphere, is represented by characteristic fruits in the Sparnacian of France, the Aquitanian of Germany and England, the Miocene of Baden and Italy, and the Pliocene of Italy. The genus Posoqueria Aublet, which includes five or six cxisting South American shrubs or trees, is represented according to Unger by both leaves and fruits in the Miocene of Croatia. The gentus Irora Linné with one hundred existing species of shrubs and small trees in all tropics is likewise recorded from the Miocene of Croatia, as is also Paictta Linné, a genus with about seventy existing species of shrubs or small trees of the Oriental tropics, which has furnished both leaves, flowers and fruits from the celebrated plant and insect beds of Radoboj in Croatia.

The genus Coprosoma Forst., with 40 existing species in Australia, New Zealand and Oceanica, was recorded by Ettingshausen from the Tertiary of Tasmania.

The genus Yauclca Linné, which has about thirty existing species 
of shruls and trees in tropical Asia and Oceanica, was identified by Lnger in the European Mincene and petrified wool of this type (Nancicoly $)$ was described by Crié from the Pliocene of Java.

The genus Morinda Linné has about thirty existing species in all tropics, especially in the Orient and the Pacific islands. I fossil species has been recorded from the Oligocene of Italy and five additional species hased on leares have been described from the Miocene of Croatia.

I fruit from the Tertiary lignites of Brandon, Termont, has been described by Perkins as Rubioides and another from the Iquitanian of Rhenish Prussia by Menzel under the name Rubiacececarpum. Geyler has identified the old world genus Gmumilea Gertner in the Tertiary of Borneo, and finally the genus Cinchonidium proposed by. Lnger for fossil fruits and leaves which were very similar to those of the existing South. Imerican genus (inchona Limé, has furnished a number of species. There are four or five in the Eocene, including the Fort Union of the western United States and the Ypresian of England; five in the late Oligocene of southeastern Europe; about eight Xiocene species, one coming from the Esmeralda formation of Nevada and the balance being European.

The family is thus seen to have been well represented in fossil floras throughout the Tertiary, but the small proportion of the existing genera with fossil representatives and the incompleteness of the record of those with fossil representatives renders untrustworthy any generalizations that might be made from the present facts.

Under Incertc sedis are grouped fourteen species of the Wilcox flora. These include two forms referred to Calycites; two to Antholithus and ten to Carpolithus. It would be quite useless to attempt any botanical discussion or comparison of these uncertain forms, such remarks as they suggest being more suitably confines to the discussion of the individual species.

Joms Hopkins Unitersity,

April 25, 19I4. 






Berry, Edward Wilbe/The affinities and d 
